Andrews University

Digital Commons @ Andrews University

\title{
Factors Associated with Pastoral Preaching on Financially- Related Topics Within the Missionary Church
}

Terry A. Zeitlow

Andrews University

Follow this and additional works at: https://digitalcommons.andrews.edu/dissertations

Part of the Practical Theology Commons

\section{Recommended Citation}

Zeitlow, Terry A., "Factors Associated with Pastoral Preaching on Financially-Related Topics Within the Missionary Church" (2013). Dissertations. 1569.

https://digitalcommons.andrews.edu/dissertations/1569

https://dx.doi.org/10.32597/dissertations/1569

This Dissertation is brought to you for free and open access by the Graduate Research at Digital Commons @ Andrews University. It has been accepted for inclusion in Dissertations by an authorized administrator of Digital Commons@ Andrews University. For more information, please contact repository@andrews.edu. 


\section{Andrews \$university}

Seek Knowledge. Affirm Faith. Change the World.

Thank you for your interest in the

\section{Andrews University Digital Library of Dissertations and Theses.}

Please honor the copyright of this document by not duplicating or distributing additional copies in any form without the author's express written permission. Thanks for your cooperation. 


\section{ABSTRACT \\ FACTORS ASSOCIATED WITH PASTORAL PREACHING ON FINANCIALLY RELATED TOPICS WITHIN THE MISSIONARY CHURCH}

by

Terry A. Zeitlow

Chair: Duane Covrig 


\section{ABSTRACT OF GRADUATE STUDENT RESEARCH}

Dissertation

Andrews University

School of Education

\section{Title: FACTORS ASSOCIATED WITH PASTORAL PREACHING ON FINANCIALLY RELATED TOPICS WITHIN THE MISSIONARY CHURCH}

Name of researcher: Terry A. Zeitlow

Name and degree of faculty chair: Duane Covrig, Ph.D.

Date completed: March 2013

\section{Problem}

The Bible gives significant direction and insight concerning financial stewardship. One of the roles of pastors is to teach biblical principles, including these financial concepts and practices. While there have been a few studies on pastoral preaching and teaching on financial matters, no known studies examine factors related to pastoral preaching on finances in smaller evangelical communities. This study focused on senior pastors in the Missionary Church, and factors that predicted their frequency in preaching and teaching about financial topics. The Missionary Church was selected because its five theological traditions (Anabaptism, pietism, Wesleyan-holiness movement, Keswickianholiness movement, and evangelicalism) value personal faith commitment including 
stewardship. This promised to provide insight into the factors that influence pastoral preaching in this important area of Christian living.

\section{Method}

Because of the exploratory nature of this study and the desire to see how evangelical pastors compared to previous studies, a survey design was chosen. Senior, preaching pastors from the Missionary Church denomination in the United States and Puerto Rico were sampled. Surveys were personally distributed to pastors at 15 district meetings between October 2011 and June 2012. English or Spanish versions of the surveys and consent forms were used.

The survey data were entered into SPSS version 19 and analyzed in three different ways. First, descriptive statistics were used to analyze 14 demographic questions. Second, exploratory factor analysis was performed on the 28 independent variables to determine if there was empirical support for the personal, institutional, and social constructs of the study. Principal Component Analysis (PCA) was chosen as the extraction method (observing loadings $>$.50) using oblique rotation with pattern matrix. Lastly, binary logistic regression was used with Factor 1, Factor 2, and 11 regrouped demographic variables to identify predictors of preaching on financially related topics.

\section{Results}

Of the total number of senior, preaching pastors in the Missionary Church denomination in $2012(N=464), 67.9 \%$ participated in the study $(N=315)$. Most of the respondents were between the ages of 40 and 64 (71.8\%). White/Caucasian (64.1\%) and Hispanic/Latino (24.1\%) were the two largest ethnic groups. An overwhelming majority 
of the pastors were married (96.5\%) and 67\% had at least one child living at home. About half the surveyed pastors had churches with fewer than 100 people (54.3\%), while 32.3\% had weekly attendance between 100-249. Most pastors (73\%) reported a bachelor's degree or above, with $81 \%$ of pastors indicating they attended a college with a Christian emphasis or obtained their degree from either a Christian college or seminary. Most of the participants surveyed had been in ministry in some capacity between 10 and 34 years (66.9\%). While there were part-time and bi-vocational pastors in the denomination, most pastors (73.7\%) worked full-time in their churches.

The data revealed four main findings. First, over 92\% of pastors in the Missionary Church preach about financially related topics at least once a year. About $43.5 \%$ preach three or more times, $22.2 \%$ preach twice annually, and $25.4 \%$ preach one time annually. Second, exploratory factor analysis identified two factors that were primary predictors of preaching/teaching on financially related topics. Factor 1 had a theme of financial training and church finance. Factor 2 had a theme of pastoral beliefs on giving and stewardship. Third, when considered together with Factor 1 (financial training/church finance) and Factor 2 (pastoral beliefs on giving and stewardship), pastors who had been in ministry over 10 years were more inclined to preach/teach on financially related topics two or more times compared to pastors who had been in ministry for less than 10 years. Fourth, when considered together with Factor 1 (financial training/church finance) and Factor 2 (pastoral beliefs on giving and stewardship), pastors in congregations of larger churches $(250+)$ were more inclined to preach on financially related topics three or more times a year as compared to those in congregations of smaller size. 


\section{Conclusions}

While most previous research suggested pastors and congregations did not favor preaching on financially related issues, this study found widespread support and practice for preaching on financial issues by pastors in the Missionary Church. Factors that most predict preaching on financial issues are (a) supportive personal beliefs on giving and stewardship; (b) education and training and a willingness to attend future training on financial issues; (c) personal commitment to giving/tithing; (d) openness of the congregation to address such topics from the pulpit in church; (e) more years of ministry experience; and (f) larger size of congregation. This research also supports prior findings that link commitment to faith traditions and more preaching on financial matters as leading to more generous giving.

Several recommendations can be made from this study. First, pastors (a) are encouraged to create a mentoring program for younger pastors; (b) involve church members who have experience in specific financial areas as a part of an overall church plan to teach financial principles a pastor may feel inadequate addressing; and (c) continue to challenge church attendees with messages on financial matters. Second, leadership within the Missionary Church should (a) work with Bethel College to ensure all ministry students take a course or receive training on biblical financial principles and church finance; (b) encourage all churches to engage in offering optional studies for congregational growth in this area; and (c) use the biennial General Conference as a chance to offer training to pastors. Lastly, future research has an opportunity to build on this study. Further study is needed to see (a) if there are links between more regular pastoral preaching and generous giving; (b) if the results of this study would be similar if 
duplicated in another evangelical denomination; and (c) if pastors preach only on tithing/giving versus another financial topic included in the Bible such as debt, contentment, cosigning, investing, inheritance, etc. 
Andrews University

School of Education

\title{
FACTORS ASSOCIATED WITH PASTORAL PREACHING ON FINANCIALLY RELATED TOPICS WITHIN THE MISSIONARY CHURCH
}

\author{
A Dissertation \\ Presented in Partial Fulfillment \\ of the Requirements for the Degree \\ Doctor of Philosophy
}

by

Terry A. Zeitlow

March 2013 
(C) Copyright by Terry A. Zeitlow 2013

All Rights Reserved 


\title{
FACTORS ASSOCIATED WITH PASTORAL PREACHING ON FINANCIALLY RELATED TOPICS WITHIN THE MISSIONARY CHURCH
}

\author{
A Dissertation \\ Presented in Partial Fulfillment \\ of the Requirements for the Degree \\ Doctor of Philosophy
}

by

Terry A. Zeitlow

APPROVAL BY THE COMMITTEE:

Chair: Duane Covrig

Member: Jimmy Kijai

Member: Timothy Erdel

External: Annetta Gibson
Dean, School of Education

James R. Jeffery

Date approved 
Dedicated to my wonderful wife, Jill, and my daughters Maggie, Mari and Maycee, who have sacrificed and provided encouragement and strength to me while pursuing this important work. It

is with great admiration, respect and appreciation

that I share the joy and accomplishment of this dissertation with them. 
TABLE OF CONTENTS

LIST OF TABLES ……......................................................................... vi

LIST OF FIGURES …............................................................................. vii

LIST OF ABBREVIATIONS ...................................................................... viii

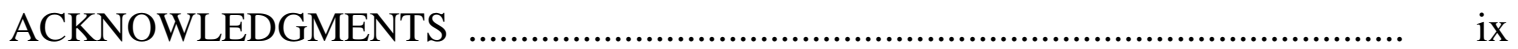

Chapter

1. BACKGROUND AND INTRODUCTION ................................................... 1

Introduction and Background ........................................................... 1

Significance of the Study .......................................................................

Statement of the Problem ..................................................................... 5

Purpose ............................................................................... 5

Research Questions ........................................................................ 5

Conceptual Framework ........................................................................... 5

Research Design ......................................................................... 7

Assumptions ............................................................................... 10

Delimitations ............................................................................... 10

Definition of Terms .................................................................... 10

Summary and Organization of the Study …………………………..... 11

2. LITERATURE REVIEW ........................................................................ 13

Introduction ................................................................................... 13

Data, Demographics, and Empirical Research on Churches and

Finances ................................................................................ 13

Stewardship ................................................................................ 15

Personal Factors ............................................................................ 18

Fear ......................................................................... 18

The Need to Be Liked ................................................................. 19

Education and Training ............................................................. 20

Personal Finances ......................................................................... 23

Words and Actions of the Congregation ........................................ 24

The Pastor Knowing Who Gives What .......................................... 25

Pastors' Feelings, Thoughts, and Personal Testimonies ................ 26

Social Factors ................................................................................ 28

Materialism and Consumerism ................................................... 28

Today's Giving Less Than Depression Levels ............................... 31 
Those Who Give Are Healthier, Happier Individuals ................... 33

Confronting Issues of Materialism and Giving ............................ 36

Preaching as a Positive Social Influence ......................................... 37

Institutional Factors ............................................................................ 39

Overview of Giving in America .................................................... 39

Triggers That Increase Giving Participation and Levels ................ 41

Inward Focus Trends in the Church ........................................ 41

Gender .................................................................... 43

Education .......................................................................... 44

Higher and Lower Income Families ....................................... $\quad 45$

Free-Riding …………...................................................... 45

Importance of Religious Involvement ……………….......... 47

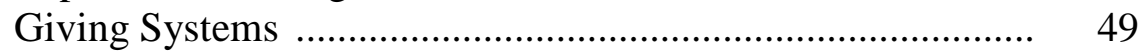

Role of Other Studies: Financial Peace University and Crown

Financial Ministries ............................................................. 50

Evangelicals and Giving ................................................................... 52

The Missionary Church ................................................................. 55

The Five Traditions _....................................................................... 56

Missionary Church Missions ....................................................... 58

Missionary Church Stewardship Perspective ………………......... 59

Summary ............................................................................. 59

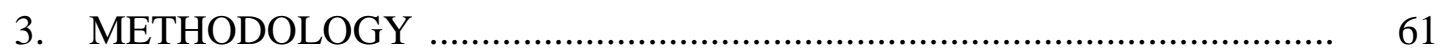

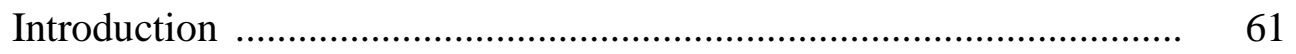

Research Questions .......................................................................... 61

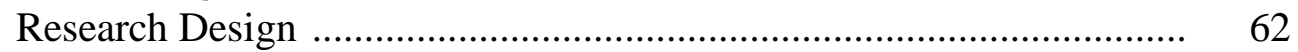

Population and Sample ................................................................... 63

Research Instrumentation ................................................................... 65

Description ....................................................................... 65

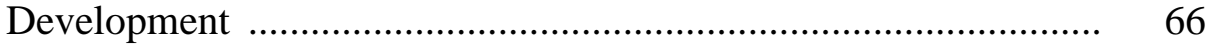

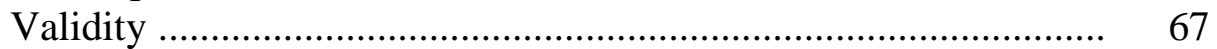

Pilot Study ........................................................................... $\quad 70$

Research Procedures .............................................................................. $\quad 71$

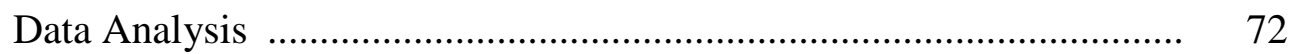

Descriptive Statistics ............................................................... 73

Factor Analysis ........................................................................... 73

Sample Size .................................................................... 74

Principal Component Analysis (PCA) …………………....... 74

Rotation of Factors ………………………………….......... 75

Identifying Each Factor ........................................................... $\quad 76$

Scree Plot ...................................................................... 77

Naming and Defining Factors …………………………......... $\quad 77$

Reliability and Scale Scores ................................................. $\quad 78$

Binary Logistic Regression ...................................................... $\quad 78$ 
4. RESULTS OF THE STUDY

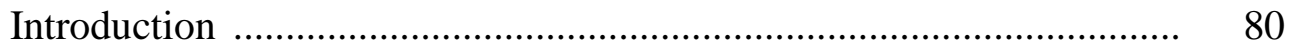

Demographic Characteristic of Respondents ..................................... 81

Results by Research Questions .......................................................... 87

Research Question 1 .............................................................. 87

Research Question 2 ........................................................... 88

Preliminary Analysis ............................................................ 88

Assumptions ............................................................. 88

Factor extraction and rotation ......................................... 89

Interpretation of the solutions ………............................... 91

Reliability and scale scores ............................................... 93

Research Question 2 Restated ............................................... 94

Case 1: Preach once or more times annually vs. not at all.. $\quad 94$

Case 2: Preach two or more times annually vs. once or not at all........................................................... 96

Case 3: Preach three or more times annually vs. two or less ……....................................................... 99

Summary of Major Findings ……...................................................... 102

5. SUMMARY, CONCLUSIONS, AND RECOMMENDATIONS ............... 104

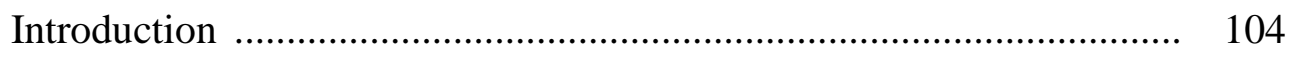

Context of the Study ......................................................................... 104

Statement of the Problem …………................................................... 105

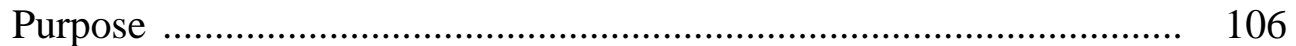

Research Questions ........................................................................... 106

Research Design and Procedures ....................................................... 106

Data Analysis ............................................................................... 108

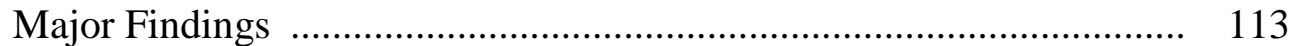

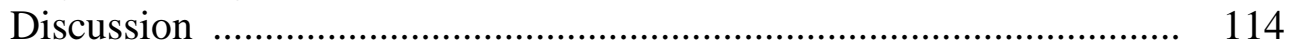

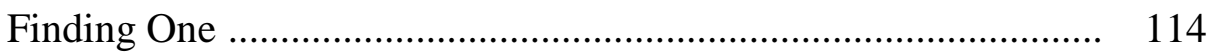

Finding Two ........................................................................... 118

Finding Three ……................................................................. 124

Finding Four ……........................................................... 128

Conclusion .............................................................................. 133

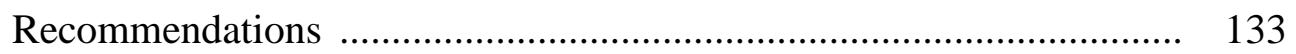

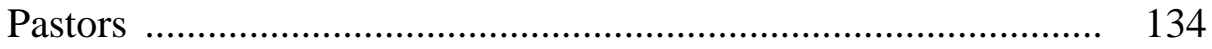

Leaders .............................................................................. 134

Recommendations for Future Research .............................................. 135

Appendix

Summary .................................................................................. 136

A. ENGLISH SURVEY QUESTIONNAIRE ……………………………... 137

B. SPANISH SURVEY QUESTIONNAIRE ................................................. 147 
C. OPERATIONAL VARIABLES …………………................................. 157

D. VARIABLES WORKSHEET …………………................................ 165

E. FREQUENCY STATISTICS FOR INDEPENDENT VARIABLES ........... 172

F. CORRESPONDENCE ………………………................................. 182

REFERENCE LIST …..................................................................... 188

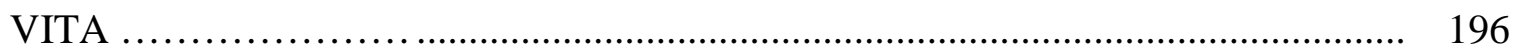




\section{LIST OF TABLES}

1. Missionary Church by District, Office Location, Number of Churches and Pastors, Number of Hispanic Churches and Number of Hispanic Pastors

2. Missionary Churches-Total District Pastors, Total Survey Participants by District, District Participation Percentage and District Survey Percentage .....

3. Description of Respondents

4. Description of Respondents $(N=315)$ on How Many Weekend Messages a Pastor Completely Dedicates to Preaching/Teaching on a Financially Related Topic

5. Measure of Sample Adequacy Criterion

6. Factor Model, Principle Component Analysis, and Pattern Matrix

7. Factor Analysis Descriptive Statistics and Cronbach’s Alpha Reliability Statistics

8. Case 1: Full Model, Variables in the Equation

9. Case 2: Full Model, Variables in the Equation

10. Case 2: Restricted Model, Variables in the Equation

11. Crosstabulations for Years in Ministry, Preaching Two or More Times

12. Case 3: Full Model, Variables in the Equation 100

13. Case 3: Restricted Model, Variables in the Equation

14. Crosstabulations for Church Attendance, Preaching Three or More Times 101

15. Missionary Church Historical Giving 


\section{LIST OF FIGURES}

1. Conceptual Framework Diagram …............................................................ 6

2. Scree Plot for Principle Component Analysis ............................................ 90 


\title{
LIST OF ABBREVIATIONS
}

\author{
MC Missionary Church \\ U.S. United States \\ PCA Principal Component Analysis \\ PAF Principal Axis Factoring \\ EFA Exploratory Factor Analysis
}




\section{ACKNOWLEDGMENTS}

This work would not be possible without the help and support of so many who have assisted me in this journey. To each of you I am truly grateful.

Thank you to Dr. William “Bill” A. Hossler, president of the Missionary Church, and to each pastor who took time to participate in this study. My prayer is this effort will contribute to expanded ministry and efforts for the Gospel to be proclaimed.

Thank you to my committee: Dr. Covrig, chair, for your overall guidance and remarkable enthusiasm; Dr. Kijai, methodologist, for incredible work, you are truly gifted; and Dr. Erdel, for your support and insightfulness. This page would be incomplete without expressing my sincere thanks to the IT staff and library staff at Bethel College and especially Mark Root. My highest praise to you! Of course there is not a better Leadership and Learning Group than mine; you are each special to me and your encouragement was always appreciated.

Thank you Jill, Maggie, Mari, and Maycee! Tears flood my eyes as I think about the sacrifice you have all made. My greatest title will never be "Dr.," it will always be husband and dad! 


\section{CHAPTER 1}

\section{BACKGROUND AND INTRODUCTION}

\section{Introduction and Background}

What could be accomplished through Christian ministry causes if there were another $\$ 46$ billion available per year? How many more missionaries could be sent to the field? How many more people could be provided with clean water, or fed, or clothed? How many more people languages could be interpreted for Bible printing and distribution? Forty-six billion dollars is what Smith, Emerson, and Snell (2008) estimate could be available if committed Christians gave $10 \%$ of their after-tax income. Ten percent would be a significantly higher amount than the current $1 \%$ to $3 \%$ percent that research showed people actually contribute (Barna, 2008; Smith et al., 2008). Why is there such a large discrepancy between the reality and the potential in giving?

This concept of tithing (giving 10\% of one's income) is just one example of the many financial topics taught in the Bible. In fact, the Bible is full of instruction on a variety of financial matters. There are roughly 500 verses explicitly on prayer, less than 500 verses explicitly on faith, but more than 2,350 verses on money and possessions (Dayton, 1996). Alcorn (2001) mentions that 15\% of everything Christ said dealt with financial topics, more than His teachings on heaven and hell combined. Sixteen of the 38 parables Jesus presented centered on how to handle money and possessions. Within the 
topic of money and possessions, there are a variety of issues addressed by the Bible.

These include such things as investing, wealth, taxes, debt, honesty, cosigning, inheritance, working, compensation, and giving, to name a few.

If the Bible speaks to financial areas as much or more than any other topic, and if Jesus Christ emphasized His teaching using financial illustrations, then it would seem that the financial area would be one of concentrated teaching in churches. According to Smith et al. (2008), this does not appear to be the case:

Prior research has shown that very many pastors and priests are uncomfortable in communicating with the members of their congregations about their responsibility to give money generously. Clergy discomfort with talking about and training for handling money is a well established fact. One national study of clergy, for instance, showed that 77 percent of U.S. clergy are very or extremely satisfied with their seminary training on theological and liturgical issues, but a mere 7 percent are similarly satisfied with their seminary training on financial duties. The same survey revealed that while 83 percent of U.S. pastors are very or extremely satisfied with their experiences of pastoral duties, only 33 percent are similarly satisfied with their experience in handling financial matters. (p. 72)

Furthermore, John Ronsvalle and Sylvia Ronsvalle (as cited in Hoge, McNamara, \& Zech, 1997) state that only $6 \%$ of pastors answered favorably the statement: Most pastors enjoy preaching about money.

This research indicates pastors often feel unprepared and cautious about speaking on financial matters. They may not have received the training on how best to teach on financial themes or how to disciple others into good financial stewardship. In many cases, they may not know how to manage their own personal financial lives. This lack of training in the financial area during their professional development may be a factor that has kept pastors from addressing financial issues.

The link between pastoral teaching on financial themes and member giving raises concerns about varying factors influencing pastors in this area. Smith et al. (2008) 
provided the most comprehensive of all recent work in this area. They suggested several

pastoral thoughts about this issue.

Pastors related to us how sensitive the issue of money is for many of their parishioners and how uncomfortable that makes them talking about it and so pastors kind of struggle with actually saying anything about it out loud.... Some pastors told us that talking about money with their congregations is one of the biggest challenges in their entire vocations, something they have to work very hard to address. . . . Pastors also spoke frequently and unhappily about the pressure they feel from the congregations to not talk too much about money.... The struggle that some pastors have with money in their churches is complicated by their uneasiness around their own personal handling of money. ... Many pastors also stated that they are personally uncomfortable talking with parishioners about giving money because of the direct implications of their own income. It is like I am raising my own salary.... Pastors also voiced discontent with their lack of training and denominational support for dealing with money issues. A number of them talked about having relatively little to no training or education about money in their pastoral preparation. One pastor explained, It's not something you do in seminary, at least we didn't. . . Furthermore, many pastors of all sorts mention getting negative vibes about money from other pastors. (pp. 103-106)

Citing a Lilly Foundation Study and a Christian Stewardship Association Study, Kluth (1998) reported 95\% of Christian educational institutions (colleges, universities, seminaries, and Bible colleges) offer no personal or ministry financial curriculum; 90\% of denominations offer no available (or limited) financial teaching resources to their pastors or churches; $85 \%$ of pastors feel unequipped and uncomfortable teaching on finances and giving; and 90\% of churches have no active plan for teaching biblical financial principles to their congregations (Kluth, 1998, Section 1, p. 3).

If people are going to learn to apply financial concepts such as stewardship and tithing and make it a part of their personal habits, it seems these concepts should be addressed to congregations by their pastor. Understanding the factors influencing a pastor's communication on this topic may help to improve teaching on this topic, which in turn may improve parishioners’ personal biblical stewardship. 


\section{Significance of the Study}

Because little research about church giving and philanthropy in America existed prior to 1990, the Lilly Endowment spurred and funded an initiative to find out more. The last 20 years have been a period of time when research has intensified in the area of studying giving trends. This research has centered in both church and general philanthropy. Most of the church research has involved large, mainline denominations and has tended to focus on the donor, giving percentages and what increases those percentages (Barna, 2008; Falk, Raybin, \& Rooney, 2010; Ronsvalle \& Ronsvalle, 1999; R.D. Roth, 1987; Smith et al., 2008; Zaleski \& Zech, 1992;). Studies including personal traits of donors, such as level of education (Donahue, 1994; Frederick, Tak, Kim, McDermott, \& Kou, 2009; Hoge, 1994; Luidens \& Nemeth, 1994), volunteering (Finke, Bahr, \& Scheitle, 2006; Luidens et al., 1994), church attendance (Iannaccone, 1997; Lunn, Clay, \& Douglass, 2001; Wilhelm, Rooney, \& Tempel, 2007), gender (Mesch, 2010; Zaleski \& Zech, 1992) and personal income level (Collett \& Morrisey, 2007; Hoge, 1994; Luidens \& Nemeth, 1994), to name a few, have been considered to examine the likelihood and level of donating. The tithe and pledging efforts have also been considered in various studies (Hoge, 1994; Inskeep, 1994; Miller, Parfet, \& Zech, 2001).

With no known studies highlighting smaller evangelical settings, this exploratory, quantitative study of pastors within the Missionary Church helped fill this research gap. The study provides empirical data within a smaller, evangelical denomination which revealed differences between the evangelical pastor of the Missionary Church and those from previous studies conducted in larger mainline denominations. 


\section{Statement of the Problem}

Given the central role of pastors in training their congregation in all-biblical teaching and given the lack of higher rates of giving, it is important to uncover some of the factors influencing teaching and preaching on finances. Because there is very limited study on understanding pastoral factors related to preaching and teaching on financial matters, this study addresses that problem.

\section{Purpose}

The purpose of this exploratory study was to examine the extent to which pastors within the Missionary Church preach on financially related issues and the influence of selected demographic characteristics, and personal, institutional (church), and social variables on this preaching on financially related issues.

\section{Research Questions}

Two questions guided this study. First, how many weekend messages did a pastor dedicate to preaching or teaching on financially related topics in a year's time? Second, what were the demographic, personal, institutional, and social factors that influence pastors to preach and teach about financially related issues on a regular basis?

\section{Conceptual Framework}

The main focus of this study was on the factors that influence pastoral preaching and teaching on finances. Several variables in the area of pastoral demographic information (known as demographic), pastoral personal views and experience with financial issues (known as personal), institutional (related to the church), and social factors were identified as linked to the literature. Figure 1 shows the conceptual 
relationship envisioned for this study. Each individual variable, regardless of where in the four categorical areas it lies, may have a relationship with other variables within that category. Likewise, categories, or individual variables within a category, may have a relationship with those of other categories. The objective of this exploratory effort was to find which variables do indeed impact a pastor's tendency toward preaching and teaching on financially related topics.

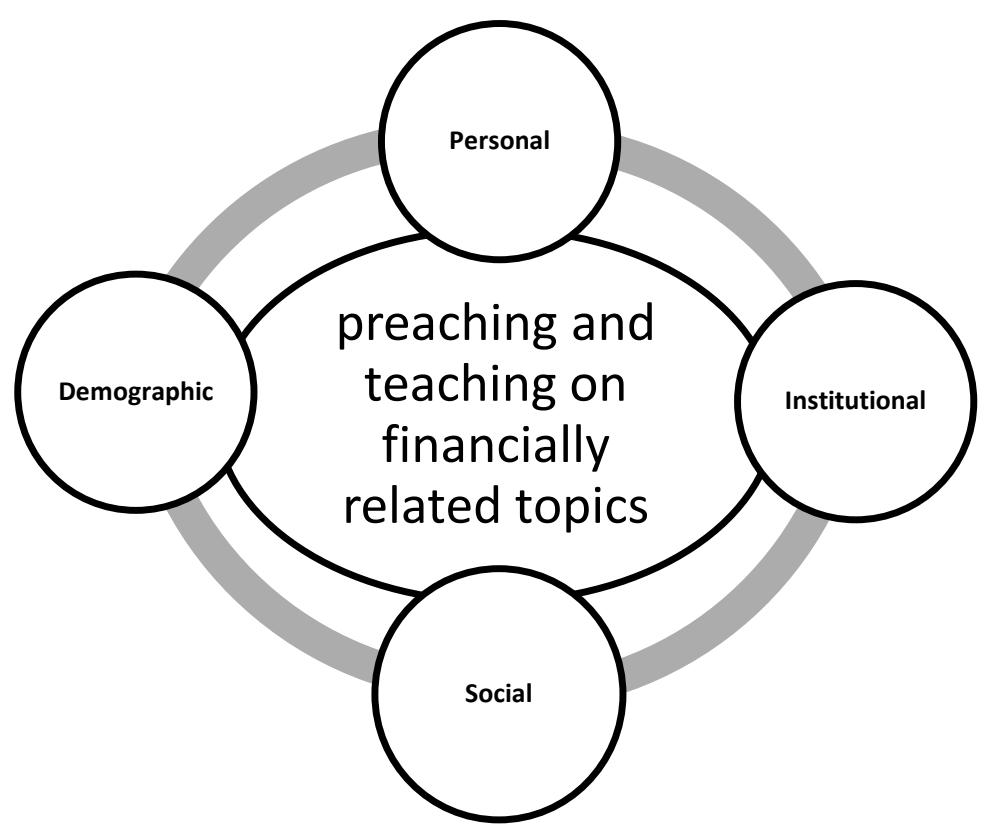

Figure 1. Conceptual framework diagram.

In many ways the Smith et al. (2008) work provided the backdrop for this dissertation and helped spur the interest of exploring these concepts with pastors in an evangelical denomination setting. Smith et al. (2008) provided the most recent and most comprehensive research. For instance, to help illustrate the institutional (church) mindset, they wrote the following hypotheses about congregational giving: 
First, if local congregational cultures maintained high expectations of and collectively honored generous financial giving, Christians would give more generously. Second, and as part of that, they would give more if Christian congregations confidently taught the normative instructions of their faith tradition regarding generous financial giving. Generous giving would also be increased by Christian leaders' strongly encouraging believers to make theologically informed, principled decisions about and commitments to generous financial giving. If Christian organizations provided multiple means by which Christians could follow through on their principled decisions to give generously in ways that were structured and routine, that would increase giving. Finally, if religious and charitable organizations established better procedures, and practices of transparency, communication, and accountability that systematically increased potential and actual donors' trust in their uses of their contributions, that would increase the financial giving of American Christians. (pp. 97-98)

In reading these thoughts, each of these conclusions was linked to factors of better communication—congregation cultures, teaching faith traditions, theologically informed decisions, procedures and transparency. They are all elements that could be communicated as a part of preaching and teaching on just one financial area in the Bible—giving. And while overall giving among Christians is low relative to the tithe, the Smith et al. (2008) study suggests that giving could easily increase if ideals were more clearly communicated with parishioners. However, research shows pastors often avoid communicating on this topic (Mead, 1998; Smith et al., 2008; Wuthnow, 1997). This study sought to explore what factors may influence this. The above quote from Smith et al. (2008) focuses on the area of giving; however, the Bible is full of other financial areas that could be taught and bring help, understanding, and direction to parishioners regarding stewardship of one’s money and possessions.

\section{Research Design}

Because of the exploratory nature of this study and the desire to see how evangelical pastors compared to the overall literature available, a survey design was 
chosen as the best way to accomplish these objectives. Survey designs are procedures in quantitative research in which the investigator administers a questionnaire to groups of people to identify trends in attitudes, opinions, behaviors, or characteristics (Creswell, 2008).

The Missionary Church denomination was chosen for the study. It represented a small, evangelical denomination, characteristics absent from known existing research. I also had access to this denomination. At the time this study was undertaken, the Missionary Church had 18 districts (including small, mission districts) across the United States (there are now 21). Fifteen of these districts held an annual meeting at which all credentialed pastors were expected to attend. The data were collected in person by a hardcopy survey instrument at these 15 district meetings. Data on the dependent variable were collected from a question related to the number of weekend messages a pastor preached on financially related issues. The independent variables were 42 demographic, personal, institutional (church), and social factors that affect preaching and teaching attitudes.

Demographic variables included: (a) district in which pastor is located, (b) pastor's age, (c) ethnicity, (d) marital status, (e) number of children at home, (f) years in ministry, (g) years as a preaching/teaching pastor, (h) currently full-time, part time, or bivocational, (i) years at current church, (j) current compensation package, (k) current church, average weekend attendance, (l) level of education, (m) degree from a Christian institution or seminary, and (n) who handles finances in the pastor's home.

Personal variables of pastors included: (a) personal giving habits, (b) personal debt situation, (c) comfort level of their compensation package, (d) comfort level on 
preaching or teaching on financial topics, (e) personal beliefs on the issue of tithing, (f) desire to be liked by congregation, (g) support of the Missionary Church’s statement on stewardship, (h) received financial training during education, (i) received financial training since entering the ministry, (j) willingness to seek or attend future financial training, and $(k)$ reflect whether a pastor should know or knows giving levels of people in his congregation.

Institutional factors included: (a) the pastor’s current church’s financial position, (b) church's feeling that pastor talks too much about money, (c) belief that those perceived to be generous people in the congregation are happier, healthy people, (d) support of the Missionary Church's Stewardship Statement, (e) pastor's knowledge of parishioners' giving, (f) annual increases in church budget address mostly operational increases, (g) annual increases in budget address outreach efforts, (h) church offers Crown Ministry Financial study as an option to the congregation, (i) church offers Financial Peace University as an option to the congregation, (j) church offers some other form of financial study to the congregation, (k) materialism/consumerism affects the congregation, and (l) credit card debt is an issue in the pastor's church.

Social factors include pastor's beliefs that: (a) all pastors do is talk about money, (b) materialism/consumerism is an issue in society, (c) credit card debt is an issue in society, and (d) society believes that all pastors do is ask for money.

Descriptive statistics, exploratory factor analysis using principle component analysis (PCA), and binary logistic regression analysis were used to study data. More information about the population and sample, survey instrument, and analysis is provided in Chapter 3. 


\section{Assumptions}

The study had two assumptions:

1. That the senior preaching pastors of the Missionary Church had an accurate understanding of the number of annual sermons they presented on a financially related topic

2. That the senior preaching pastors participating in this study would provide honest responses on the surveys.

\section{Delimitations}

This study was delimited to senior, preaching pastors of Missionary Churches. The senior, preaching pastor was the primary individual responsible in a church for delivering the weekend sermons/messages to the congregations.

\section{Definition of Terms}

The following are definitions of terms used throughout this study:

Missionary Church: A small, evangelical denomination with 473 congregations spread throughout the United States and Puerto Rico with 464 senior pastors (Missionary Church Directory, 2012). It reports a membership of 37,684 with an average Sunday morning attendance of 63,514.

Preaching/Teaching: Delivering a weekend message to the congregation.

Senior Preaching Pastor: The pastor responsible for delivering weekend messages for the congregation.

Finances: Money, possessions, investments and/or resources an individual possesses. 
Evangelical: In simplist terms the word comes from Evangelion, which means “Gospel” or “Good News” (Willmer, 1995. p. 103); one who follows the gospel or good news of Jesus Christ. (More is included on this in the literature review beginning on page 16.)

Stewardship: Recognizes God as the supplier of all resources and man is responsible to manage those in a way that honors and brings glory to God.

\section{Summary and Organization of the Study}

Although financial issues have been taught and discussed, and stewardship has been promoted within Christian communities since New Testament times, it has only been since 1990 that concerted efforts have focused on empirical research issues of money in the church and philanthropy in general. Most of this research pertaining to the church has been related to large mainline denominations and has been focused on giving trends and donors. More research was needed in understanding variables that link pastors to preaching and teaching on financial issues. This exploratory study of pastors within the Missionary Church provided such an emphasis.

This study consists of five chapters. Chapter 1 included an introduction, the statement of the problem, the research question, the conceptual framework, the justification of the study, the significance of the study, the methodology summary, the delimitations, the assumptions, the definition of terms, and the summary. Chapter 2 provides a literature review. This review focused on summarizing previous research performed in this field with special focus placed on content related to social, institutional, and personal data applying to pastoral insight related to finances and giving. Chapter 3 comments on the methodology of the study and contains all parameters used in gathering 
and interpreting research information. Because of the Hispanic growth in the Missionary Church, the survey instrument was available in both English and Spanish translations. Chapter 4 provides the results of the study. The findings were analyzed using descriptive statistics, exploratory factor analysis via PCA, and binary logistic regression. Chapter 5 discusses the findings of the study. This includes a restatement of the problem and purpose, reviews the research questions and research design, reports the findings, discusses these findings in light of literature, and, lastly, provides recommendations and a conclusion. 


\section{CHAPTER 2}

\section{LITERATURE REVIEW}

\section{Introduction}

This literature review provided background support related to the purpose and problem statements of this study. It is divided into seven main categories. The first section will give a short overview of data, demographics, and general empirical research in the area of giving and finances within religious groups in the U.S. I then briefly review concepts related to stewardship from a biblical perspective. The next three sections concentrate on issues within the three categorical variables of personal factors, social factors, and institutional (church) factors that contribute to pastoral views on issues of finances and giving. A section also reviews the doctrinal and practice issues related to evangelicals and giving. Lastly, since the study's focus is on pastors in one evangelical community — the Missionary Church—I review aspects of that denomination.

\section{Data, Demographics, and Empirical Research on Churches and Finances}

The empirical research and study on giving and related themes in the religious community is a fairly recent initiative. Hoge (1995) mentions:

I tried to do a thorough review of the research on religious giving. Numerous books discuss the theology of giving and stewardship, several nationwide polls have asked about personal giving, and a large number of books teach how to raise funds. I discovered that religious giving had seldom been studied from hypothesis-testing 
social scientific approach. This surprised me since thousands of professionals make their living in the field of philanthropy and many dollars are at stake. (p. 51) Iannaccone (1997) echoed Hoge’s comments. He mentioned a 1991 Lilly Endowment decision to provide substantial financial support for new research on religious giving and church finance that sparked efforts of exploration. With Lilly's help, 30 scholars met in 1992 and 1993 to analyze data on church giving. That initiative led to more intensive study on giving in the past 20 years. Many of those studies have examined indicators that predict a person's likelihood to financially contribute to churches and charities.

From these comments it is evident that it has only been the last 20 years in which empirical research of any significance has contributed to this field of church giving. Donahue (1994), Hoge (1994), Iannaccone (1997), Inskeep (1994), Luidens and Nemeth (1994), and Zalaski and Zech (1994) were all early contributors to this field of study. Their published research in an issue of Review of Religious Research laid the groundwork in studying giving among religious groups. Since then, others like S.L. Miller (1999), Mead (1998), Ronsvalle and Ronsvalle (1996, 1999, 2000), Smith et al. (2008), and Wuthnow (1999) have added more analysis on influences and trends on giving and other related factors in religious groups.

There has also been growth in organizations that comment on various areas of philanthropy and provide services to help groups understand trends. John Ronsvalle and Sylvia Ronsvalle not only provided research in the 1990s and significant information in their book, Behind the Stained Glass Windows, but continue to do so today through their ministry, Empty Tomb, Inc. The Barna Group has long provided studies on many Christian issues including giving. The Indiana University Purdue University campus in Indianapolis is home to the Lake Institute and the Center of Philanthropy for Indiana 
University. Their website provided a wide range of resources and research in this field. Brian Kluth performs an annual church-giving study and provided resources to pastors and churches related to issues of giving. And Christian Smith, a leading sociologist and author who provided much of the backdrop and vision for this dissertation, oversees the Science of Generosity at the University of Notre Dame. His work and the Science of Generosity website capture research on many areas of generosity including financial. The Science of Generosity has accumulated four extensive literature reviews capturing pertinent sources, authors, and titles, and were used in this study. Last but not least, Dave Ramsey’s Financial Peace University and Crown Financial Concepts provide significant resources for education and training on financial issues.

\section{Stewardship}

The idea of stewardship is crucial in the overall theology of the Christian. One's views of stewardship will likely result in personal views on money, finances, and possessions. One could get the idea that since "I am supposed to give $10 \%$ to God," one could do whatever one pleased with the remaining $90 \%$. Stewardship, however, is about more than the $10 \%$. Stewardship involves careful watch over the whole $100 \%$ entrusted to the steward or manager. The Christian, then, is the steward of what God entrusts to him/her (Ps 51:9-11 and Ps 24:1); thus overseeing or managing one’s possessions is very important. The question was asked, "Is the tithe obligatory for the Christian?" Part of this question arose from Christ’s criticism of the Pharisees (Matt 23:23). Foster (1995) noted that this criticism stemmed from the people's legalistic approach to giving, thus missing the larger mark of stewardship. 
Teaching God's people the importance of stewardship is an important function of a pastor's role. Russell (2002) spoke from personal experience as a former pastor when he said, "We want them [parishioners] to consider their attitude towards possessions as a personal and spiritual matter vital to their relationship with God” (p. 43). Wuthnow (1999) recorded that one third of those who heard a sermon in the last year said they also thought a great deal in the past year about what the Bible teaches concerning money and about the relationship between religious values and their personal finances. Ninety-two percent of those who had thought a great deal about the relationship between religious values and their finances agreed that the Bible contained valuable teaching about money. Roth (1987) noted the New Testament gave no explicit answer to the question, "What percentage should people give?” The answer he says was determined by faith, love, gratitude, and concern for God's Kingdom. It placed on Christians the single concern to give as God gave to them (p. 13). Jeyaraj (2004) also suggested giving began by surrendering one's life to the Lordship of Christ and then it flowed to help the lives of others. Giving one’s life to Christ naturally led to giving up one’s possessions and life for others. Both were interlinked. Mulligan (2007) also mentioned stewardship was connected to a fuller understanding of the faith.

It was possible a lack of stewardship meant that many of God's people lacked faith, love, gratitude, and concern for God's Kingdom. The question of the tithe was one that always arose. Russell (2002), like Foster (1995), gave reference to the Old Testament tithe in mentioning $10 \%$ of their crops and flocks were returned to God. "Today, God has given Christians Jesus Christ, the indwelling Holy Spirit, the fellowship of the church, the privilege of living in the most affluent nation in the world, plus so many personal 
blessings. You decide whether your gift should be more or less than a tithe” (p. 45). Dr.

Frances Pieper (as cited in Roth, 1987) reflected the following thought on the tithe:

Many seek some guidance on this matter and we ought not to be bashful about speaking at least 10 percent. Most tithers testify that they have experienced rich blessing in giving a tenth. I have never run across a tither who regretted being one. Martin Luther says: "Certainly the tithe comes to be the most just of all dues, since they have existed by divine testimony, almost from the beginning of the world." In addition, they seem the most reasonable. ... In every way we strive that the tithe remain inviolate.” To those who resist the suggestion of the tithe on the grounds of legalism may we suggest that they give 11 percent on the grounds of grace. (p. 13)

The importance of training and teaching cannot go unnoticed. Brooks (2006) asked an executive at a South Dakota community foundation why South Dakotans donated so much of their income to charity. Her response was immediate: "Religion! We were all taught to tithe," she told me (p. 30). People in South Dakota gave the same amount of money as people in San Francisco, even though the amount of money that they make per family was just about half of what people in San Francisco make.

Ronsvalle and Ronsvalle (1996) note that the whole area of stewardship was a measure of devotion. The way that individuals spent their money indicated something about their emotional and spiritual thermometer. In a consumer society such as the United States, it became the most readable evident measurement. The life of Christ offers the Christian a theological basis for Paul's writing in 2 Cor 8:8-9. Though Christ was rich, He became poor for the sake of mankind, sacrificing all so humanity could enjoy salvation. The giver was expected to give according to his or her ability and in the realization of the love of God (Jeyaraj, 2004).

Finally, Platt (2011) refers to 1 Tim 6:18 where Paul admonishes Timothy to command the rich to "do good, to be rich in good deeds, and to be generous and willing 
to share.” This, Paul says, was the key to being free from the deadly nature of wealth and possessions.

Ronsvalle and Ronsvalle (1996) made a telling summary about stewardship today: “Church members have changed from stewards into consumers. People were not returning a portion of their incomes to God. Rather, they are paying for services rendered by the church” (p. 31).

This opening portion of the literature review focused on the relative infancy of study in this area. I followed that by touching on the area of stewardship and the place it has in the life of the Christian. I now move to literature examining what may be influencing the emphasis on teaching and giving with the Christian and Evangelical community. I examine personal, social, and institutional factors that might especially influence pastoral communication in this important area.

\section{Personal Factors}

Though God's word said as much if not more about financial issues than any other topic in Scripture, it remains a lightning rod of sorts. Research suggested few pastors desire to spend much time on it and few parishioners want to hear anything about it (Mead, 1998; Miller, 1999; Ronsvalle \& Ronsvalle, 1996; Smith et al., 2008; Wuthnow, 1997). The following lends insight into pastoral factors that played important roles in understanding this dilemma.

Fear

Hoge et al. (1997) mentioned that one fear felt by nearly every pastor was fear of criticism, "You're always talking about money.” For the vast majority of pastors, this 
criticism was unfair. Most pastors have gone to great lengths to avoid talking about money because they know how sensitive and potentially alienating it is. Mulligan (2007) offered similar thoughts when he mentioned that one of the roles of preaching was communicating the faith, yet many clergy dreaded the approach of the stewardship season. They buckled in fear at the thought of talking about money. To listen to some, it is clear they hated the idea. Schultz (2001) believed pastors were hesitant to teach stewardship. He shared the fear among pastors that concentration on financial stewardship only invited the charge that all the church cared about is money.

Bagwell (1993) summarized, "Motivated out of fear, guilt, and even anger, the preacher speaks to the congregation about money and spirituality. The preacher preached on giving out of his or her emptiness. No one listened. No one responded. Few gave” (p. 5). It is as if today's pastor was fighting a losing battle in this area.

\section{The Need to Be Liked}

Hoge et al. (1997) noted that the discomfort of speaking about money has several sources. One was that many pastors want to be liked by their church members and they felt they would alienate members if they pushed too hard on money issues. Pastors are people too. They need friendships and acceptance just like all human beings. Hoge et al. (1997) furthered noted that most pastors were loved and respected, but they all hoped to avoid situations in which they risked losing the love and respect of their parishioners. Asking for money presented a situation of risk.

"Pastors were also keenly aware of the pressures that encouraged church members to spend money on material possessions even to the point of going heavily into debt. They were also overwhelmed by these issues” (Wuthnow, 1999, p. 71). "The only way to 
come to terms with the changes taking place after World War II was to talk about them. However, many issues involved responsible use of money in light of scriptural demands. And pastors, perhaps above all things, do not like to talk about money” (Ronsvalle \& Ronsvalle, 1996, p. 298).

This appeared to be a dilemma for pastors. On one hand, they wanted to be liked and loved by their congregations. On the other hand, there was the responsibility of teaching scriptural principles to their congregation, even those scriptural principles that might cause some parishioners to squirm. Somehow pastors needed to find ways to be spiritual leaders and also financial leaders. They needed to develop an approach to church finances that helped church members grow in their stewardship commitment without alienating them (Hoge et al., 1997, p. 6).

\section{Education and Training}

It was surprising to learn of the lack of attention such a major area like this has received in pastoral training. In fact, Mulder (1999) remarked that the strange silence about money in the life of the church was matched by inattention to money and stewardship in theological seminary curricula. Hoge et al. (1997) mentioned that the seminary leaders are not convinced that they have a responsibility to teach these topics: Over half said that the seminary curriculum was already filled, and practical management skills needed to be acquired later. S.L. Miller (1999) remarked of her research and interviews of seminary leaders that they were not uniformly supportive of the idea a seminary should teach church leaders about leadership, stewardship, and management of the churches’ resources. Ronsvalle and Ronsvalle (1996) offered several similar comments in this area, noting that seminaries believe management and financial 
instruction was something the student needed to pick up on their own. They felt seminary leaders believed stewardship was not considered an academic topic worthy of attention during the short 3 years a seminary had to work with a student.

"Over the years, seminaries have focused on scholarly academic theoretical questions, and there has been an absence of work related to practical church life," says James Waits, Executive Director of the Association of Theological Schools in the United States and Canada (Ronsvalle \& Ronsvalle, 1996, p. 157). But Al Taylor combated that by saying, "You give pastors all of this training at the seminary, and the first problem they run into in the congregation was money and you haven't taught them a thing about money” (as cited Ronsvalle \& Ronsvalle, 1996, p. 159).

One explanation for this imbalance in academic training may be in the faculty makeup of today's seminary. In days gone by, the instructors in seminaries were current or retired pastors in the denominations they served. Hoge et al. (1997) offer another insight in that many seminary instructors have never served as pastors and preached for any extended time in a congregation. Most have been lifelong academics. They went to college, earned their advanced degrees, and perhaps served some sort of internship, and then became instructors in seminary. Because those teaching have never had to generate funds or deal with a congregation, they were not going to talk to students about these things.

Pastors themselves would concur that their professional development in this area was below par. In a survey conducted by S.L. Miller (1999), fewer than 15\% said they were satisfied or very satisfied with the administrative and financial training they received. In separate research, Hoge et al. (1997) noted that pastors in Catholic and 
mainline churches said that administrative and financial duties were the least satisfying parts of their ministry. They said they never had good training. More than $85 \%$ said they were dissatisfied with the administrative and financial training they received in seminary. Ronsvalle and Ronsvalle recorded only 9\% as saying they had received adequate training (as cited in Hoge et al., 1997).

The feelings surrounding the church and finances today appeared to have soured future consideration of training in this area. When asked directly about their interest in attending financial or management-related short courses, clergy were not enthusiastic. S.L. Miller (1999) noted that only 15\% of Protestant and 14\% of Catholic clergy said they were interested in financial resource management training. In a similar study, pastors said management and financial matters were of importance, but they preferred other possible forms of leadership in this area. They want to concentrate fully on their theological, liturgical, and pastoral duties and leave management tasks to someone else (Ronsvalle \& Ronsvalle, 1996).

S.L. Miller (1999) summarized seminary financial education by noting:

The limited training opportunities that are currently available to future church leaders in the stewardship of human, physical, and financial resources normally are not a required part of seminary curriculum; they are not, in general, regarded as an integral part of the theological and pastoral education that church leaders receive in the seminary. As a result, future church leaders do not receive systematic, integrated preparation for the management dimensions of pastoral ministry. (p. 101)

Given the dire state of seminary perspective in finance outlined in these several studies, one wonders what factors could or do lead pastors to work and teach in this area of stewardship. 


\section{Personal Finances}

One of the items regarding stewardship and talking about money that bothered clergy was the fact that their salary was typically a part of the church budget. This reality was bothersome for many pastors. Ronsvalle and Ronsvalle (1996) noted one of the national denomination executives believed that many of the pastors have never been trained to handle money, so they have trouble handling their personal finances. That thought was elevated when considering ministerial staff often try to survive on marginal incomes. Given this combination of factors, a pastor found it difficult to lead parishioners into the responsible use of personal money when his or her own checkbook was not balanced (Ronsvalle \& Ronsvalle, 1996). Hoge et al. (1997) also expressed concern about how their family financial circumstances, including their own giving to the church, impacted their ability to talk about money, as well as how their message was received by church members.

The issue of a pastor struggling in his own giving can be a real source of tension. One could understand, for instance, why they would not want to preach or teach on giving. It appeared hypocritical to implore the congregation to do that which he is not. Allen (2005) said several people in his survey noted that sermons on stewardship were more credible when worshippers could perceive that the preacher lived with integrity. The pastor has to model stewardship based on personal experience. It is really an integrity issue. Southern Baptist assistant regional minister, David Wheeler, agreed: “I don't think people will give unless the pastor led by example.” But there was no guarantee that people will give if the pastor does (Ronsvalle \& Ronsvalle, 1996). 
Words and Actions of the Congregation

If talking about money and finances in the church was not hard enough in itself, it seemed to be compounded in many ways by individuals and congregations who worked to keep the topic out of the pulpit. Ronsvalle and Ronsvalle (1996) told of three specific situations in their research. One pastor described being told in his first interview with the congregational leadership board that the congregation expected one money sermon per year. Another pastor was inspired to preach what he thought was a powerful stewardship sermon in March. One of the congregation leaders made a special effort to inform the pastor that he had given a fine sermon-except that it belonged in September, not in the spring. A third pastor was enthusiastic about stewardship; a tither himself, he felt that it was his responsibility to keep the possibility of good stewardship before the congregation. He would therefore preach stewardship sermons when he felt it appropriate, regardless of the time of year. He would do this in spite of the fact that an older man, who faithfully sat near the front of the church each Sunday, stood up at the first mention of money in the sermon and walked out the long aisle in full view of the entire congregation. This gentleman explained to the pastor that he felt money was a topic totally inappropriate for the church.

These stories were not isolated ones. Mead (1998) noted pastors were excoriated for preaching too much about money because people wanted to avoid the subject and its hold on them. He noted later in his work that clergy were allowed to talk-a little-about church budgets and contributions to the church, but everything else concerning money and the people’s personal budgets was off limits. In another portion of their work, Ronsvalle and Ronsvalle (1996) mentioned an experience at a church where a guest was 
speaking about financial matters and the chairman of the finance committee spoke out saying, "We do not discuss money in this church. What gives you the right to come in here and talk to us like this?” (p. 127). Mead (1998) suggested that lay people need to step up by using their spiritual gifts and wisdom to help and share of their wealth and wisdom in teaching congregational members. Sitting back, complaining the pastor was preaching “too much” about money, and taking public offense have not helped accomplish church goals.

"Something has to give! Both in talking with clergy about what they say and from examining the transcripts of their sermons, we must say that clergy have tiptoed around the topic of money as if they had walked through a mine field” (Wuthnow, 1999, p. 147). He further revealed that $68 \%$ of the working public, in fact, agreed that money was one thing and morals and values were completely separate. The church members were just as likely as non-members to hold this view. Stowell (1987) told a story that suggests a more positive possibility for money. He noted how one time he apologized for speaking about money. Two members reproved his apology after the service saying, “Giving is a privilege and act of worship” (p. 23).

\section{The Pastor Knowing Who Gives What}

Research by Ronsvalle and Ronsvalle (1996) also considered whether pastors should know who gave and who gave what in their congregation. It was a controversial issue because there are several potential downsides; however, on the positive side, the more a pastor knew, the better he or she could address financial matters. At a stewardship workshop, 97 pastors and 112 regional officials were asked, “The pastor’s knowledge of what individual members give to their church can be a helpful assessment of an 
individual member's spiritual health" and "Most church members do not want pastors to know how much individual members contribute to the church.” Seventy-eight percent of pastors and $82 \%$ of regional officials agreed with the first question. Eighty-three percent of pastors and $70 \%$ of regional officials agreed with the second question. Pastors appeared to agree that they could benefit from knowing, but also agreed there would be member opposition. It was suggested that members preferred to remain anonymous, possibly because giving levels were embarrassingly low. In earlier research, Ronsvalle and Ronsvalle (1996) quoted Hugh Magers who said he believed that the clergy who do know what people in their congregations gave were better teachers on stewardship. “Terrible pressure was brought to bear that no one knew," he said. "Episcopalians would tell you astounding things about their sexuality, but they would not talk at all about their financial life” (p. 135).

\section{Pastors’ Feelings, Thoughts, and Personal Testimonies}

Earlier in this section, comments were given on the idea that pastors, like all other people, wanted to be liked and appreciated. But the thought of preaching on finances or the whole area of money in general also initiated other feelings or realities in a pastor's life as well. These feelings included guilt, uncertainty, or being uncomfortable, to name a few. Because this area is so stressful for pastors, it was important to hear what they were saying and include some of their thoughts for consideration. Consider the following from Mead's (1998) work: "Leading the fall stewardship campaign was often uncomfortable for me. In a sense I kept being aware that I was asking people to contribute to my salary, which usually was the biggest item in the budget”; "I often felt guilty about our family situation, aware that my children were paying fairly substantially because of my 
professional choices. I saw my kids having less than their friends, many from the congregation”; “I believed in and practice proportional giving/tithing, but couldn’t get over the feeling of resentment of people of means who gave little in comparison to what seemed to be their resources"; "Clergy often feel the need to raise questions about the materialist assumptions of society at the same time they have a voice inside crying out for more of the fruits of that materialism for themselves"; "Clergy often feel patronized by people who wanted to pass along to them their leftovers of clothing or furniture. The hard part was saying 'Thank You' especially when you were choked up with anger” (p. 129-130). Bagwell (1993) told the story of a minister headed to retirement, and he remembered with glee that there would be no more stewardship campaigns or stewardship sermons.

Wuthnow (1997) made the point that by virtue of their position, clergy were members of the middle class but not "of it" as often their income is not reflective of that economic level. As members of the middle class, they experienced the same pressures that many of their parishioners do. They did not want to appear to have all of the answers to questions about personal finances, because they do not.

Pastors experienced a full range of emotions. There were obviously those who struggled mightily in this area. Then there were others who were making an effort, whether they saw results or not, to at least preach the topic. Implicitly, the silence in churches about matters of money communicated only that nobody in the church had any problem (Wuthnow, 1998, p. 144). This was certainly not the case. Wuthnow (1997) also mentioned that although this was likely to remain a difficult area, some pastors who 
enjoy preaching sermons linked to Scripture have found preaching this topic enjoyable. Others have found it easier when honestly speaking to their own worries and mistakes.

Though some were making the effort to increase efforts in this area and while others would always give the standard one message per year, as S.L. Miller (1999) notes, few clergy found substantial satisfaction in their administrative and financial duties. She continued by noting that this striking absence of enthusiasm for administrative and financial duties was clearly evident, and to a nearly identical extent, both in Protestant and Catholic clergy. That being mentioned, the Alban Institute in conjunction with the Lake Institute on Faith \& Giving (2009) reported that almost 40\% of the pastors ( $N=$ 1,496) in their study preached or talked about charitable giving either slightly more (30.4) or significantly more (9.4) than they did in the previous year.

\section{Social Factors}

This section looks at social factors that provide insight into the area of finances and giving in people's lives and its possible connection to pastoral teaching on this topic. Consideration is given to materialism, consumerism, and credit card debt, giving comparisons of today to the Great Depression and World War II, reasons people give, personal happiness, and the encouragement for pastors to preach on finances.

\section{Materialism and Consumerism}

Hubbard (2001) recorded in his work the results of a U.S.A. Today poll that asked people to finish the line, "I'd give more but ..." Among the top responses included 79\% who said they had no excess income to give. In considering why this might be, it was 
important to consider societal pressures people face to gratify physical desires. Pressures included feelings of failure if an individual does not achieve financial goals (Wuthnow, 1997).

Consumerism was defined as "the theory that an increasing consumption of goods is economically desirable, a preoccupation with and an inclination toward the buying of consumer goods” (“Consumerism,” 1984). Materialism was defined as "a doctrine that the only or the highest values or objectives lie in material well-being and in the furtherance of material progress. Also, a preoccupation with or stress upon material rather than intellectual or spiritual things” (“Materialism,” 1984). The emphasis on these two terms in this section related to exploring whether American culture today was reflective of these concepts.

Platt (2011) posed the question, "Is materialism a blind spot in American Christianity today?” In his work, Platt (2011) likened materialism to a war, a war against the heart. He referred to it as a constant battle to resist the temptation to have more luxuries, to acquire more things and to live more comfortably. In referring to Platt, no assumption was made that all the respondents in the USA Today survey were Christians. But, they were all human and experience what Wuthnow was suggesting concerning social pressure.

An interesting indicator of today's attitude towards money was seen in the extension of personal credit. Woosley and Schulz (2011) used several sources in providing very relevant information regarding credit card use and debt in America. There were 609.8 million credit cards held by U.S. consumers with the average credit card debt per household with a credit card at $\$ 14,750$. This helped contribute toward an overall 
total U.S. consumer debt of $\$ 2.40$ trillion as of June 2010. In 2008, half of college undergraduate students had four or more credit cards. The total bankruptcy filings in 2009 reached 1.4 million, up from 1.09 million in 2008. Penalty fees alone from credit cards added up to about $\$ 20.5$ billion in 2005 . The average credit card-indebted family in 2004 allocated $21 \%$ of its income to servicing monthly debt compared to the $13 \%$ dedicated to debt payments among all households.

Hubbard (2001) argued that our money gets tied up in culture-driven "wants” beyond our basic needs. Because purchasing by credit was extending that which one does not have, the credit card statistics speak to the amount of "wants" people seem to have. The culture preaches self-indulgence and consumption; this is what these revealing statistics point to. These statistics helped provide insight into why $79 \%$ of people believe they do not have any excess income to give. And though it is important to note that these statistics do not just apply to Christians, it is assumed Christians were carrying their fair share based on Barna research, which seldom finds much statistical difference between contemporary Christians and non-Christians. Wuthnow spoke to the tremendous increase in consumerism even though there is evidence of increased church attendance and religious belief in the U.S. He simply made the point that people are struggling financially (as cited in Ronsvalle \& Ronsvalle, 1996).

In one church interview, Wuthnow (1999) recalled a pastor saying one main problem for people in his congregation is they simply don't think carefully enough about their money. They do not maintain budgets or records of their expenses. Platt (2011) quotes 1 Tim 6:6, "Godliness with contentment is great gain.” In the context of this passage, contentment was described as having food and clothing, having the necessities 
of life provided for. When Jesus said, 'Where your treasure is, there your heart will be also,' He was drawing a connection between money and human identity. If money and human life were imminently woven together, then giving money was giving one's self away” (Mulder, 1999, p. 158).

The actions of culture seemed to indicate a vast number of people were not concerned about giving of themselves, as Mulder suggests, but of getting for themselves as society implored. “It's easy to understand why we tiptoe around a subject of stewardship. Money was still a god to many church members” (Russell, 2002, p. 43). Willmer (1995) noted, "The materialism of our culture was the dominant issue and the church has not combated materialism with its own set of values. People in the church often feel that if they take the biblical teaching on stewardship to heart, they would have to give up a lot that they don't want to do without” (as cited in Ronsvalle \& Ronsvalle, 1996).

The information presented suggests that materialism and consumption of goods and services were contributing factors to increased debt in people’s lives, which promoted a barrier to more generous giving in one’s personal life.

\section{Today’s Giving Less Than Depression Levels}

Scripture admonished it was more blessed to give than receive (Acts 20:35). The research just reviewed suggests that contemporary trends push against this scriptural admonishment. Ronsvalle and Ronsvalle’s (1999) study compared today's giving to the days of the Great Depression and World War II. In their study they revealed that between 1922 and 1933, giving was slightly above 3\% of income. This figure from the days of the Great Depression dropped to equal, or slightly below, 2\% during World War 
II, and then eventually recovered to exceed 3\% from 1957 through 1963. The permember contribution figure of 3.11\% dipped to 2.46\% by 1995 .

This represented an astounding figure to most, if not all, to think that with the affluence that exists in the United States, people were giving a greater percentage of their income during the Depression and Second World War than was being given today.

Although 225 million Americans give away money each year, another 75 million never give to any causes, charities, or churches (Brooks, 2006). Giving patterns in the United States indicated the church was losing market share among its own members. For the first time in history, a few societies, United States included, found most of their people had money beyond what was needed for their personal basic needs (Ronsvalle \& Ronsvalle, 1996). "Discretionary income” was a reality for most of the population, and advertising agencies very intentionally targeted that income, turning "wants into needs." This seemed to support the previous information on materialism and played a part in contributing to the mounting debt being incurred in people's lives. Ronsvalle and Ronsvalle (1996) referred to a report going back as far as 1972 that concluded: “As people see it, the main thing blocking church support simply was a surprising urge for more affluent living. ... Rival attractions seem to be gaining more of the religious dollar" (p. 35). Stowell (1987) cited well-known seminary professor and president, Haddon Robinson, who said, "You can tell a lot about a man’s spirituality by looking in his checkbook. Giving was a reflection of where one's heart was toward God. I tell my people that making Him Lord of their money was a key of serving Him without distraction” (p. 25). Platt (2011) noted the way we use our money was a barometer of our spiritual condition. 
This attitude and desire for more seemed to run counter to Christian teaching. "For Jesus, charity was not a matter of giving out of a state of plenty, but involved the possibility of losing everything for the sake of the needy. This was a radical principle!” (Jeyaraj, 2004, p. 168) There seemed to be a lack of knowledge and understanding of "how well off people are" who lived in the U.S. Platt (2011) helped to bring this to light when he mentioned that the reality was, if you and I had running water, shelter over our heads, clothes to wear, food to eat, and some means of transportation (even if it is public transportation), then we were in the top $15 \%$ of the world's people for wealth. He further brought to the forefront that nearly half the world lived on one to two dollars per day and more than a billion people in the world live and eventually die in poverty.

Foster (1995) supported the lack of generosity and concern for others when she wrote that those in need appeared not to be a priority of modern society. World hunger and the situation of the homeless in America do not tend to hold integral places in church or denominational budgets. Today's Christians were prone to hear and respond to the demands of the poor, the disinherited, and the desperate only when their cries posed a threat to one's own life. Ronsvalle and Ronsvalle (2000) challenged church members who only contributed to keep the church structure functioning but failed to conduct efforts to support the physical and spiritual needs of local and global neighbors. They suggested something needed to happen for "others" rather than "self" in keeping with Scripture.

Those Who Give Are Healthier, Happier Individuals

Everyday consumers, who carry large debt loads from the purchases they made to secure the "good life," receive monthly bills to remit payment. It is possible the initial joy 
of that original purchase is swallowed up in reality of monthly payments that continue on for years in some cases. On the other hand, giving seemed to bring on a different feeling. Brooks (2006) uncovered evidence that has convinced him that charity is important to our personal happiness, health, and the ability to express ourselves humanly. Elizabeth Dunn says, "The effects of altruistic spending were probably akin to those of exercise which can have immediate and long term effects. Giving once might make a person happy for a day, but if it became a way of living, it could make a lasting difference” (as cited in Youngsteadt, 2008, para. 4). Kristoff (2010) noted one study found people who focused on achieving wealth and career advancement were less happy than those who focused on good works, religion, or spirituality, or friends and family. University of Virginia psychology professor, Jonathan Haidt, noted one thing that made a lasting difference to contentment was to work with others on a cause larger than oneself. They found this "sacrifice" was a huge source of fulfillment and satisfaction (as cited in Kristoff, 2010, p. 1).

Supporting these thoughts were comments in a generosity devotional thought by Maxwell (2003). He noted that selfishness inclined people toward failure because it kept them in a negative mental rut. In his entry, Maxwell quoted Dr. Karl Menninger (2003), who mentioned that developing a giving spirit helped a person overcome some of the feelings of deficiency in a positive and healthy way. Maxwell, in the same context, mentioned Kevin Myers (2003), who said most people were too insecure to give anything away. Most people who focus all their attention on themselves do so because they feel that they're missing something in their lives, so they're trying to get it back. Menninger 
also noted that generous people were rarely mentally ill people. “A person was less likely to focus on himself if he was trying to help someone else” (Maxwell, 2003, p. 358). More than two decades ago, economist James Andreoni theorized that people who gave experienced an internal satisfaction that he called the "warm glow." Others have called it the "helper's high"—a physical sensation that increased feelings of self-worth and made people want to give again (as cited in Keen, 2010, para. 9). Besides having such a positive mental effect on an individual, there were other reasons why people gave. Brooks (2006) noted social scientists had identified a multiplicity of giving motives, including the "warm glow" one felt from giving, the provision of goods for one’s own social group (such as a church), guilt, duty, social pressure, and the pursuit of status. Hoge et al. (1997) reported the four main motives for church giving were: (a) reciprocity with a social group, (b) reciprocity with God, (c) giving to attract attention to self, (d) thankfulness, while also noting most of the social science research on gift giving had been done on secular, not religious philanthropy.

The study by Hoge et al. (1997) also revealed pastors have indicated that church members sometimes made gifts out of feelings of gratitude. They told of religious people—although possibly not a majority—who developed a sense of gratitude for the many gifts God had given them, and they made gifts to churches and missions as a response. Jeyaraj (2004) provided a biblical perspective, indicating the three major reasons to give included support of the Christian preacher/teacher, the missionary who brought the gospel and the poor people in the churches using Gal 6:6, 1 Cor 9:11-14, and 1 Tim 5:17-18 as scriptural guidelines. 
According to Christian Smith, "People who were generous are happier, healthier and doing better in life. There was something about learning how to get beyond one's self and helping other people that was good for the giver. And there is so much need in the world” (as cited in Keen, 2010, final para.).

\section{Confronting Issues of Materialism and Giving}

Though discussed in more detail in the section on personal pastoral factors (what kept clergy from preaching more often on financial topics), it is appropriate to touch on this now considering the large emphasis on materialism in this section. It was no secret that people seemed to want to avoid hearing messages that had to do with giving and other financial topics, and pastors wanted to avoid giving them. Bagwell (1993), who spoke from the personal experience of a pastor, mentioned that even the body language and posture exhibited in the pulpit indicated how totally uncomfortable pastors felt preaching for giving. The congregation sensed that something was wrong, and they left stewardship sermons feeling "whipped" and guilty. But the issue of talking about money was not only taboo in the church, it was everywhere. In the public at large, fewer than one person in four ever talked about his or her personal finances with close friends. Among church members, only 3\% say they ever discussed their finances with fellow church members. And only $4 \%$ had ever discussed their finances with a member of the clergy (Wuthnow, 1997). Woosley and Schulz (2011) also mentioned that discussing credit card debt was highly taboo. Three of their top four responses referenced financial issues; debt, salary, and monthly mortgage or rent were simply not discussed.

Wuthnow (1997) even discussed the lack of communication about money among family members when he said, "In our culture, though, people generally shield even their 
own children from the information about family finances and consider it improper to ask the price of ordinary purchases” (p. 141). Though members of society seemed to have no problem spending money and even extending themselves financially for future years, discussing it was another issue and one that seemed traditionally to bring discomfort to the sender and receiver of the message.

Perhaps deep inside people know their spending was out of control, and they felt guilty. Messages about finances made them feel like the child sitting in the corner for doing wrong. Perhaps they felt guilty knowing their spending had placed great limitations on what their potential giving could do for the cause of Christ and other secular charities. But maybe there is hope on the horizon as Wuthnow mentioned (1999) church members at least gave lip service to the idea that faith should help them to be less materialistic, less obsessed with making money, and more committed to higher aims and ideals.

\section{Preaching as a Positive Social Influence}

There was some research evidence that financially based messages from Scripture were influencing Christians, and that pastors played a role in this. Wuthnow (1999) mentioned that among church members nationally, 65\% said the Bible contained valuable teachings about money. Allen (2005) shared that most interviewees who commented on stewardship sermons said that such preaching had played a positive role in helping them become better stewards. Several pointed out that sermons had been important in persuading them to tithe. Allen (2005) further recorded the testimony of interviewees who expressed the opinion that preachers should talk about stewardship more than they do: "I'd like to see us do a little bit more about stewardship and I'd like to see that 
addressed a little bit more directly. I want to know my purpose, my being and how I live out that purpose and that being. How do I become a better steward of God?” (pp. 2-3). Mulligan (2007) also confirmed these thoughts when writing that lay people implied they want to learn about stewardship. Analysis of the interviews indicated that there were some congregational criticism and personal reasons for preachers' anxiety about speaking about finances, but most laity were interested in Christian teachings about money.

Research that showed positive impact in pastoral teaching on finances offered encouragement for pastors. Alcorn (2001) wrote because there is a fundamental connection between our spiritual lives and how we think about and handle money; we may try to divorce faith from personal finances, but God sees them as inseparable. He continued by noting that when Jesus warns us not to store up treasures on earth, it is not just because wealth might be lost; it is because wealth will always be lost. Either it leaves us while we live, or we leave it when we die. No exceptions!

The words of Mead (1998) perhaps summarized it best. "We begin with a financial crisis and it leads to a spiritual crisis. We begin with financial meltdown with our own budgets, and we discovered a financial meltdown of our own personal lives. Perhaps the financial crisis was the door that led us to deal with the hunger we had to find our way home to God” (p. 122). Many people in the U.S. have placed themselves in financial straits, and many people wrestled with this concept of wanting for self as opposed to giving to others. He suggested this financial crisis can lead people to evaluate what is most important and therefore lead then to consider their faith in light of their personal finances. The social pressures to accumulate material possessions was strong 
and the battle to resist this temptation was challenging to all, including Christians (Platt, 2011).

\section{Institutional Factors}

In this section, institutional or church factors related to stewardship are examined. I first review financial giving among American Christians. Next, demographic factors predicting giving are reviewed. These include gender, level of education, volunteering and church involvement, income levels, free riding, and giving systems. Another section reviews popular resources within the U.S. that help churches with financial issues. These include a review of the work of Dave Ramsey and Financial Peace University and Crown Ministries, the two most popular Christian stewardship and personal finance resources used in churches today.

\section{Overview of Giving in America}

One of the Old Testament financial obligations for Israelites, God's people, was the tithe. Smith et al. (2008) noted that nearly all American Christians belong to churches that teach believers, as stewards of the belongings with which God has blessed them, to give money generously for the work of God's kingdom. Most Christians belong to churches that teach tithing — the giving of $10 \%$ of one's income. However, very few people actually follow this guideline.

Smith et al.'s (2008) recent study focused on large mainline denominations, and the results showed that most groups give between 1.5 and $2.0 \%$ of income. Denominations included in the study were Presbyterians, Episcopalians, Lutherans, Methodists, Catholics, and others who did not fall into a category. Also included in the 
study were Jews, Jehovah’s Witnesses, and Mormons. Baptists gave 2.5\% of their income, and Pentecostals and "other” Protestants gave about 3.5\%. Smith et al. (2008) also noted that a minority of American Christians gave away no money at all to any organization, needs, or causes. These numbers can be compared to Zaleski and Zech’s (1992) study that revealed 1960-1974 data showing Protestant and Catholic giving at $2.2 \%$ in the $1960 \mathrm{~s}$, with a drop to $1.6 \%$ in the 1970 s and a further decrease to $1.1 \%$ in 1980. An increase has obviously taken place since then, but nothing close to resembling the tithe.

Leading researcher of Christian concerns, George Barna (2008), also documented that certain segments of the population were more likely to contribute $10 \%$ of their income. Those included: evangelicals (24\%); conservatives (12\%); people who had prayed, read the Bible, and attended service during the past week (12\%); charismatic or Pentecostal Christians (11\%); and registered republicans (10\%). Other significant research information of note from Barna (2008) included that among born-again adults, $9 \%$ contributed one-tenth or more of their income, $5 \%$ of all adults tithed, and $84 \%$ of all adults donated some money to churches or non-profit organizations, which was a figure that has remained consistent in recent years; of that, $64 \%$ of the public donated some money to a church, synagogue, or other place of worship.

In 2008, along with annual giving, nearly \$23 billion was left to charities through donors’ wills, according to research by the Center on Philanthropy for Giving USA Foundation. Bequests accounted for $7 \%$ of total giving that year (Sargeant \& Shang, 2010, p. 4). Though Barna (2008) recognized that a high percentage of people give 
money to charity annually, Sargeant and Shang (2010) noted that only about 5\% of people leave a donation to charity in their wills.

These figures and giving percentages were important as they represented the total number of all contributions by Americans in a year's time. Falk et al. (2010) noted that in 2009, \$303.75 billion was contributed to churches and non-profits. This was actually a 3.6\% drop from 2008 giving and the steepest decline since 1956. It should be noted at the writing of this document that the United States was experiencing an economic recession, which could explain the drop in giving. Of that total, \$251.21 billion was contributed by individuals or bequests.

While those donations represented an impressive number and there were further explanations in Falk et al (2010) report on where those dollars were directed, that number fell short of the possibilities. Smith et al. (2008) spend the first 25 pages of their work making a case for what could actually happen in America and around the world if $90 \%$ of committed Christian households gave away 10\% (a tithe) of their after-tax income. Doing so would increase annual giving by another $\$ 46$ billion and as much as $\$ 85.5$ billion in another illustration they presented.

\section{Triggers That Increase Giving Participation and Levels}

The following research illustrates factors that trigger giving and help bring understanding to how and why people give.

\section{Inward Focus Trends in the Church}

Luidens and Nemeth (1994) conducted research on the Presbyterian Church and Reformed Church in America, doing so because they had nearly complete record-keeping 
systems going back to 1860 . These churches showed giving going toward their own internal purposes and denominational benevolent purposes. This internal focus has continued to gradually increase. Reasons cited for this were the tremendous increase in expenses as churches increased pastoral staff and began pension plans, insurance, housing costs, and real wages. Because of an increased female labor force, once active volunteer tasks have been exchanged for professional services. Churchgoers over time have become consumers in the religious marketplace. The heightened demand for specialized services and professionally staffed programs forced congregations to turn inward in their spending patterns. Zaleski and Zech (1992) also noted that lower Catholic costs for minister compensation, if they were found to exist, would serve as an economic explanation for lower Catholic contributions. There simply did not appear to be a need to give.

This internal focus was further supported in that the bottom line indicated that all causes outside the local congregation have had a flat income line for 25 years (Mead, 1998, p. 27). Mead also mentioned that budgets typically only give 2 to $4 \%$ to outreach efforts. Sociologist Reginald Bibby noted, “Observers have drawn attention to the reality of routinization, whereby groups tend to become turned inward, focusing upon themselves as organizations, rather than on the original purpose that brought them into being (as cited in Ronsvalle \& Ronsvalle, 1996, p. 100).

Roth (1987) mentioned that it is no small wonder that the people claim that all the church is interested in is money, or the church was always asking for money. It is a perception that was real and backed by the limited outreach that occurs within today's church. Church leaders may have to lay a renewed foundation, addressing basic attitudes 
toward money, the role of faith and relationship to giving, and why members should invest in the work of the church, rather than spend their money in other ways (Ronsvalle \& Ronsvalle, 1999, p. 211). Negative stereotyping could be playing a role in these views regarding church. Bagwell (1993) cited a Madison Avenue advertising firm survey where people described churches as a place where they ask for money and people are sad.

Ronsvalle and Ronsvalle (1999) offered a solution that could help reverse negative giving trends. They claim $81 \%$ of pastors and $94 \%$ of regional officials agreed there is no overarching vision to challenge members. Simply providing vision and shifting from an inward focus could be factors that help change this perception. Schulz (2001) also contributed to this discussion, saying it may be that there is a certain fear among some pastors, the fear that to teach on financial stewardship was to invite the charge that all the church wanted was money.

\section{Gender}

Another important socioeconomic characteristic was gender. A 1990 study showed Catholic women gave the same as men but Protestant women gave a larger percentage than Protestant men (Zaleski \& Zech, 1992, p. 464). It is clear women have played a major role in philanthropy. Women entering the work force in larger numbers have been a leading contributor to many churches’ inward expenses rising. Many of these current expenses in previous years were volunteer hours provided by women. The last three decades, however, have seen a shift in the landscape. Sixty percent more women were now in the labor force and college-degreed women tripled between 19702008. Also, in 2008 , $36 \%$ of working women held college degrees compared to $11 \% 30$ years ago (Mesch, 2010). 
The study performed by Mesch (2010) also revealed information regarding the generosity of women in giving. Eliminating married households (because they statistically were likely to give more than singles), her study focused on male/female households in the categories of (a) never married, (b) divorced/separated and (c) widows/widowers. She considered five different income levels. Her study results included (a) in all five income groups analyzed, female head of households were more likely to give to charity then a male-headed households; (b) in every income group, females gave more than men with the exception of the second lowest income bracket (23,509-43,500); (c) female-headed households were more likely to give than men in comparable households with the exception of a widow/widower, and (d) female-headed households gave more than men in comparable households except for a widow/widower.

\section{Education}

Luidens and Nemeth's (1994) work showed that the level of one’s education also correlated positively, although less strongly, with family giving. Donahue’s (1994) findings noted giving to non-religious charities or social services organizations was related to education and income. Hoge (1994) mentioned all studies that include education as a factor have a positive relationship with religious giving. The recent study by Frederick et al. (2010) noted two key findings including those with more education were more concerned about equity and making the world a better place. They were less concerned about providing for people's basic needs and allowing the poor to help themselves, which contrasts those with less education. Those with postgraduate educations were even more highly so. 


\section{Higher and Lower Income Families}

Luidens and Nemeth (1994) noted that of the socioeconomic items, family income was clearly the stronger predictor of family giving. Members who earn more, gave more dollars. Though they gave more, Greeley’s research (as cited in Zaleski \& Zech, 1992, pp. 463-464) revealed higher income families give a lower percentage of their income to churches; he noted that the difference was even more profound for Catholics. Hoge (1994) also noted this negative relationship between higher income and lower percentage of giving to religion. Collett and Morrissey (2007) cited those with fewer resources tended to make the greatest sacrifices when it comes to charitable giving. Further, those with lower incomes were often ineligible for the tax incentives that lure those with more means into donating.

\section{Free-Riding}

Zaleski and Zech (1992) noted congregation size and attitude toward the importance of church and religion were two critical considerations determining support for a church's mission and, thus, the extent of free ridership. A free-rider was defined as a church attendee or member who gave no or very little money yet enjoyed all of the benefits associated with being a part of a church body. A free-rider effect was clearly present as was evidenced by the negative coefficient on members. The estimate elasticity was suggested that if a congregation grew by $10 \%$, contributions per member would fall by about 25\%. Hoge (1995) also suggested that a free-rider could as easily be referred to as “easy rider.” Only when the public good was in danger of disappointment would this individual offer to pay more and up to the true perceived value. Free-riding accounted for the widely noted tendency for people to give much more in emergency situations. It 
also accounted for the higher level of giving by members who were well informed about true costs of running a church (Hoge, 1995, p. 67).

Olson and Perl (2005) also used the term cheap riders. Iannaccone (1997) even noted with fewer free-riders, average commitment levels would rise even higher because the remaining, committed members contributed even more once they knew that their contributions were not being "stolen" away by low committed members (as cited in Olson \& Perl, 2005, p. 125). Evidence supported broad estimates that 30-50\% of resident members gave little or nothing of record to their congregation. Present giving patterns establish that these people were not going to contribute to the general operation or current mission of the church (Ronsvalle \& Ronsvalle, 2000, p. 100).

R.J. Miller et al. (2001) noted in their study that parish size had a negative effect on average household giving, meaning that as a congregation grew, families gave less. Finke et al. (2006) also related that income had a positive effect on congregational giving, and congregational size had a negative effect. Size also had a significant and negative effect on member involvement and the number of opportunities for involvement.

Ronsvalle and Ronsvalle (2000) mentioned free-riding has been offered by some researchers as a major explanation in denominational differences in church giving. The theory stated that giving was higher in evangelical denominations because they have a stronger motive of reciprocity with God and more obligatory visible indicators of commitment. Olson and Perl (2005) noted that, compared to other congregations, strict, theologically conservative congregations have less skewed giving distributions and thus appear to have fewer free- and cheap-riding participants, just as Iannaccone (1997) predicted. Olson and Perl (2005) also mentioned that from the individual's point of view, 
it is rational to free-ride so long as the benefits of the social organization can be obtained without having to pay for them. However, if all individuals act in this same rational manner, the end result would be insufficient resources to produce the benefit.

\section{Importance of Religious Involvement}

Family contributions were strongly related to levels of personal involvement in congregational life. Attendance at church and Sunday school and amount of involvement in congregational leadership positions were also strongly related to family giving (Luidens \& Nemeth, 1994, p. 209). Luidens and Nemeth's (1994) study also showed that the wealthiest members were slightly less involved in the church's activities, on average, than the less wealthy. Donahue's (1994) work found among their sample of church members, giving to one's own congregation was found to be strongly influenced by income and the religiousness of one's spouse, while giving to other religious charities was more strongly influenced by personal religiousness. Engagement and church involvement appeared to be clear indicators of financial support for one’s congregation. Both of Hoge's $(1994,1995)$ studies mentioned all studies indicate that strong personal faith is associated with higher contributions. He also confirms what has been mentioned that church commitment and attendance were strongly associated with giving. Schervish and Havens (1997) continued with supporting information when they stated:

Those who were motivated mainly either (a) to fulfill a business or community obligations or (b) to change the way society works tended to give smaller percentages of their income than those who are motivated by loftier, more focused, more selfless goals of (c) meeting religious beliefs or commitments, (d) enhancing the moral basis of society, (e) teaching people to be more self-sufficient. (p. 245)

As seen in others, Iannaccone's (1997) study and Lunn et al. (2001) also concurred that attendance was an important factor in giving. 
Lunn et al. (2001) noted conservative theological beliefs were associated with greater total giving, greater giving for normal congregational uses, and for nonPresbyterian religious organizations, and liberal theological beliefs were associated with greater giving for denominational purposes and for nonreligious charities.

Finke et al.’s (2006) study also provided insight, mentioning that increasing involvement and involvement opportunities in the local congregation and high congregational requirements increased the level of giving.

Wilhelm et al. (2007) also affirmed the importance of attendance and its correlation to giving in their point-in-time study, which compared prewar cohorts to those of the baby-boom generation. Less giving and less attendance by baby boomers were indicators of declining generosity. Their study further expressed that results provide evidence that generational change was at the foundation of recent changes in American religious giving and religious involvement.

Lastly, Davidson and Pyle’s (1994) research spoke to the future potential of understanding the link between participation and generosity:

Our analysis demonstrates the value of linking interactionist and exchange frameworks and looking at variables which combine both perspectives. Apart from income, the two variables with the most effect on giving are participation and intrinsic religiosity, the two which link members' self-concepts (symbolic interactionism) and self-interest (exchange theory). Our results have several implications for church leaders. If religious leaders desire higher levels of financial commitments from their members, they need to appreciate the special potency of conditions which link faith with benefits, values with interests and beliefs with rewards. Leaders should stress participation in all aspects of church life-collective activity such as worship and religious education, as well as devotional activities such as private prayer and Bible reading. By increasing members' involvement in all aspects of church life, leaders are also likely to increase members' contributions to the church. (p. 193) 
Mark Ottoni-Wilhelm, professor of economics at Indiana-Purdue, says, “It’s wrong to look at this as a money problem. The drop in giving followed the involvement pattern. Because people were not as involved, the giving pattern traces it” (as cited in Freedman, 2010, para. 12). This statement is important to this study from the standpoint that though people who were involved gave more, there were fewer people who volunteered their time. Freedman (2010) also quoted Villanova University economist, Charles Zeck, who said, "The baby boomers learned skepticism as products of the Vietnam and Watergate years. This was in contrast to the so-called Greatest Generation who came during the New Deal and World War II, who developed trust in institutions” (para. 9).

The State of Church Giving through 2000 (Ronsvalle \& Ronsvalle, 2000) concluded that much of the philanthropy education that took place in the U.S. did so in a religious congregation. The independent sector series on giving has repeatedly found a correlation between regular worship attendance and the level of charitable giving.

\section{Giving Systems}

In the study performed by Inskeep (1994), congregations using a system of financial pledges had higher levels of giving. A stewardship emphasis and an emphasis on tithing also showed a correlation. Hoge (1994) also related information on studies showing that those that used pledge systems and those that used stewardship materials in local churches were associated with higher giving. His 1995 study also suggested reciprocity was a major explanation for religious giving and distinguished four general types: reciprocity with family, reciprocity with a social group, reciprocity with God, and reciprocity with history. 
R.J. Miller et al. (2001) conducted a study measuring 12 stewardship programs that various parishes sought to implement. In the end, only two of those, the establishment or upgrade of a parish finance or stewardship committee and the implementation of a parish tithing effort, were significantly associated with a growth in parish household giving.

\section{Role of Other Studies: Financial Peace University and Crown Financial Ministries}

In Chapter 1, some statistics were shared that showed the lack of training in the church about financial concepts. In recent years, however, some of these opportunities have grown. The Alban Institute and Lake Institute on Faith \& Giving (2009) showed that $27.7 \%$ of their surveyed churches $(N=1,517)$ offered classes or events on personal finance or giving. The two most popular resources were Financial Peace University and Crown Financial ministries.

Financial Peace University was founded by popular radio and seminar figure Dave Ramsey. Ramsey teaches practical advice on finances from what he learned in overcoming his own personal financial struggles. He is forthright on his radio show and in his seminars and is upfront with people about specifically dealing with their personal debt and finding their way to financial freedom. The key phase of his movement is, "If you will live like no one else, later you can live like no one else” (Ramsey, 2007, p. 5). This main concept attests that if you will live in a way now that rids yourself from financial bondage, you will be able to live the rest of your life without the bondage that debt places on one's life. The person who does this will have more opportunities to live life differently than the one strapped by financial issues. 
Ramsey’s Total Money Makeover (2007) strongly stresses destroying one’s credit cards and establishing a home budget. This is then followed by creating an immediate $\$ 1,000$ emergency account, focused effort on retiring debt, followed by growing a larger emergency fund, maximizing retirement investing, college provision, retiring the home mortgage, and then further building wealth. Ramsey's counsel is listened to weekly by over 3 million listeners on radio stations across the nation (Ramsey, 2007), and his study is offered through a variety of venues including churches, webinars, and video feeds. Materials are available in stores and on his website, www.MyTotalMoneyMakeover.com.

The Alban Institute and Lake Institute on Faith \& Giving (2009) included personal testimonies of those who had received training from various seminars. The following was mentioned about Ramsey's work: “Financial Peace University has been of great help to our congregation. People had become slaves to their debt. Asking them to give more without first setting them free from debtor's prison just generated guilt, not results” (p. 24).

Crown Financial Ministries is the merger of two ministries, Crown Ministries, founded by Howard Dayton, and Christian Financial Concepts, founded by the late Larry Burkett (1939-2003). Burkett wrote several best-selling books and was the host of a nationwide radio program that bore the ministry name. Today, much of his work continues through the merger with the ministry Dayton started.

Crown Financial Ministries differs from Financial Peace University in that a more biblical perspective is offered. The flagship program for Crown Financial Ministries is a 10-week small-group study that takes 10 different financial concepts or principles and looks at them from a biblical perspective. The 10-week study includes Scripture 
memorization and weekly questions to be answered before meeting for the small-group study. A significant commitment is needed on the part of the participant. Along with the

weekly study, the participants memorize Scripture, create a home budget, consider legacy planning at least to the point of will preparation, and make a commitment to begin making changes in personal habits to become a good steward of one's possessions. Crown also offers materials for children, high-school students, Sunday School classes, and a Capstone Course for seniors considering their full legacy plan. Like Financial Peace University, Crown Financial Ministries also has a nationwide radio program.

\section{Evangelicals and Giving}

Among the Christian-giving segments in the country, evangelicals have been shown to be most generous. Defined by denominational traditions, evangelicals make up nearly one fourth of the American population, with about two thirds of that number categorized as "committed" on the basis of regular church attendance and other factors that indicated active adherence (Noll, 2007, p. 8).

In order to understand the evangelical culture and their bent toward generosity, it was helpful to understand the theological underpinnings of their faith. Four main ideas helped define this: First was the distinct tie to the gospel and the desire to reach people who do not know Jesus Christ. The second was the desire to preserve a nation perceived by them to be founded on biblical principles (though not all evangelicals would agree with this as it may not be historically accurate). The third was a moral and spiritual responsibility to avoid the material and maintain a God-centered worldview, and fourth is a response to biblical stewardship (Willmer, 1995, pp. 107-108). Furthermore, Noll 
(2007) mentioned that the evangelical religion is a religion of the person engaged with the Bible. "To lose that engagement would be to lose something essential” (p. 25). Hoge (as cited in Noll, 2007, p. 12).) supported Willmer (1995) and Noll (2007) when he suggested "three factors were foremost as reasons" why evangelicals contribute at a higher level than other Christian denominations. First, evangelicals were more involved in their churches, and church involvement was the strongest, single predictor of giving. Second, evangelicals hold to strong beliefs in Bible truths, which is also another predictor of giving. This includes a commitment to stewardship. Third, evangelicals disproportionately considered religion important in their lives. The evangelical's faith also included belief in God's promises that God will take care of the faithful, and it gives higher priority to a spiritual life than the material life. White (1989) supported Hoge's thoughts when he said there was a strong correlation between fervency of faith and giving and volunteering. The most important indicators of who gives in America were frequency of church attendance, Bible study, and prayer (as cited in Willmer, 1995, p. 101). He also referred to a 1992 study which stated that a much higher percentage of evangelicals practiced their faith more actively than did either Catholics or mainline Protestants. Mulder (1999) expanded on this thought in his work, which expressed the difference between conservatives, moderate, or liberal Protestant giving. Apparently the difference was explained by “commitment” and "evangelical theology.”

To support these notions, Barna’s (2008) research cites actual financial figures that clarified the differences in giving levels among the three dominant sub-groups of Christians:

Evangelicals, the seven percent of the population who are the most committed to the Christian faith, donated a mean of $\$ 4,260.00$ to all non-profit entities in 2007. Non- 
evangelical born again Christians, who represent another 37 percent of the public, donated a mean of $\$ 1,581.00$. The other 42 percent of the Christian population who are aligned with a Christian church but are not born again donated a mean of $\$ 865.00$. (Barna, 2008, p. 2)

Barna (2008) also noted that evangelical Christians distinguished themselves in their generosity. More than four out of five (83\%) gave at least $\$ 1,000.00$ to churches and non-profit entities during 2007, far surpassing the levels reached by any other population segment studied. Barna’s giving figures on evangelicals, as contributors of the church and para-church, would support Noll's (2007) work in suggesting that generous funding of para-church organizations was the jewel in the crown of evangelical philanthropy. Many para-church organizations put forth the priority of reaching people by meeting a need and then sharing the gospel. This is in line with the outreach nature of the evangelical who also tends to get more involved in faithfully funding missionaries. Noll (2007) also notes that individuals who gave more to non-church causes (para-church) also gave more to their home church.

Willmer (1995) further noted that:

Evangelical giving was generally characterized by giving to ministries they can readily understand and put their faith in. Evangelicals generally gave to individuals or projects more than institutions. Approximately 15 to 40 percent of selected evangelical church membership giving was going to para-church ministries, and in a few congregations it reached as high as 50 percent. (p. 106)

This would likely be the case of a person who did not see enough outreach effort reflected in the regular church budget.

While evangelicals could boast higher giving percentages as a group than most, they were still behind the tithe (10\%) level taught by most of their churches. Wesley K. Willmer, Vice President for University Advancement at Biola University and former Board Chair of the Christian Stewardship Association (CSA), spoke about trends among 
evangelicals. "We often put ourselves first and God second. It's a historical problem. Pastors were not trained, so they seldom knew what to say and (when they did know) were afraid to say it” (as cited in Ronsvalle \& Ronsvalle, 1996, p. 129). Willmer feels that Christians, including evangelicals, have separated areas of life, with little connection between faith and money.

This section on evangelical emphasis was important to this study as it framed the theological background that often guides evangelical communities. Because the Missionary Church is an evangelical denomination, understanding this basic theology is important in understanding the context of this study. The next section gives an overview of specific faith traditions that meshed to form the Missionary Church.

\section{The Missionary Church}

With the emphasis in this study on the pastors of Missionary Churches, it was vital that a perspective of this evangelical denomination be presented. Engbrecht and Erdel (2003) noted the deepest roots of the Missionary Church were in the Anabaptist Reformation. Most early congregations and members came from Mennonite or Amish backgrounds. Slightly less direct connections with Anabaptism came through the River Brethren and the "German (Mennonite) Branch” of A. B. Simpson’s “Christian Alliance (now known as the Christian and Missionary Alliance)” (p. 1). Erdel (1997) mentioned there are five theological traditions that have guided the Missionary Church. These strong traditions emphasized personal commitment and sacrifice, which was often expressed through personal giving. Those simple lifestyles sometimes made it possible to support a missionary for every 50 church members, a ratio that is today closer to 1 in 
every 400 regular attenders (Erdel, 2012, p. 77). Most important for this study, each theological tradition valued personal faith commitment including stewardship.

\section{The Five Traditions}

The following provides a brief summary of the five traditions that molded the Missionary Church and guide much of its theology and practice today. The first tradition was Anabaptism. This was described as follows: strong commitment to radical biblicism, the primacy of the teachings of Jesus, lifelong discipleship and a distinctively Christian lifestyle, personal decision and believer's baptism, the leading of the Holy Spirit and humble service (Erdel, 1997). J.D. Roth and Nolt (2012) noted that what first distinguished the Anabaptists from other reformers was "their insistence that the decision to follow Christ was a genuine choice that could not be coerced” (p. 11).

The second tradition was pietism. This was described as follows: attention to crisis conversion, baptism by immersion, personal spiritual disciplines, godly family life, revivalism and renewal, heartfelt patterns of corporate worship, aggressive evangelism, and sacrificial missionary outreach (Erdel, 1997). Burkholder (2012) mentioned that what all pietists had in common was a deep longing to experience God in a way that stirred the emotions and captured the affections. This "heart religion”/“love theology” displayed itself in relief work and meeting physical needs inside and outside of the church.

The third tradition was the Wesleyan-holiness movement. This was described as a full-orbed vision of the Christian faith including Christian authority as derived preeminently from Scripture, yet also and very importantly from tradition, reason, and Christian experience, all under the guiding presence, illumination, and direction of the Holy Spirit. The Christian life entailed conversion, justification, sanctification, and 
Christian perfection, with each step bringing the believer toward the goal of a holier life. The Christian witness encompassed both faith and works, inner spiritual experience and visible spiritual disciplines, personal piety and social concerns, and both separation from the world and the transformation of it (Erdel, 1997). Blowers (2012) notes, "Wesleyans believe that God has authoritatively made Himself known so that believers may be assured that their lives give testimony to the redeeming and restorative power of God. Our human experience of conversion, justification, sanctification, and being perfected in Christian love testify to God's amazing grace” (p. 51).

The fourth tradition was the Keswickian-holiness movement. This movement emphasized: the deeper Christian life, personal renewal, and victorious Christian living; biblical ecumenism which brings together all true believers; the efficacy of systematic biblical exposition for Christian growth and purity, and particularly on A. B. Simpson's focus on Jesus Christ as Savior, Sanctifier, Healer, and Coming King (Erdel, 1997). Kostlevy (2012) mentions that "in its classic form, Keswick teaching holds that the sinful nature is not extinguished or eradicated, but counteracted by a second distinct religious experience following salvation, the baptism of the Holy Spirit” (p. 66).

The final tradition was evangelicalism, which may entail and overlap with the first four, but also touches other traditions. This tradition was described as follows: biblical authority to be rightly defined and personally acknowledged (the formal principle of the Reformation, so that Evangelicals were "Bible Believers") and the need for personal conversion and regeneration in light of God's great work of atonement on the Cross, which offers forgiveness, and the new life must be appropriated by faith as a gracious gift of God (Erdel, 1997). The term evangelical is not as easy to define as one 
might think. Erdel (2012) mentions "there have been seven or so major historic meanings connected to the term evangelical” (p. 75). The core theological definitions of evangelicalism, "being born again” and the view of the Bible as uniquely authoritative, were settled during the Reformation. These specific beliefs of the evangelical may lend understanding to the earlier section of this literature review, which showed commitment to and higher levels of giving by the evangelical.

Though these five traditions have their own unique bents, the common theme that draws them together and provides emphasis for this study is their personal faith commitment which included stewardship. The idea of following Christ was more than just a head decision with lip service. It was a decision of the heart that expressed itself through following biblical principles, including financial instruction.

\section{Missionary Church Mission}

Much growth within the Missionary Church in the United States came between 1989 and 2003 when the denomination set a goal to plant new churches. With 289 churches in 1989, just 16 more than at the time of the merger of the United Missionary Church and The Missionary Church Association in 1969, the Missionary Church exceeded goals and grew to just over 400 by 2003. Dominated by Anglo churches at the time, the denomination grew by 117 churches where Anglos were the minority member. This type of effort brought the denomination closer to its core values and purpose statement which proclaimed that the Missionary Church, in obedience to Jesus Christ her Lord, is committed: To being holy people of God in the world, and to building His church through world-wide evangelism, discipleship, and the multiplication of growing churches, all to the glory of God (Missionary Church Purpose Statement, n.d.). 


\section{Missionary Church Stewardship Perspective}

The focus of this study revolved around preaching and teaching on financially related issues. Because of this, it was important to understand the Missionary Church's denominational perspective on stewardship. The following excerpt from the Missionary Church Articles of Faith and Practice states their stance:

(a) God's ownership of all things creatively and redemptively is unquestioned in the scriptures. Since we are saved by grace and the death of Christ provided our ransom, our whole being, body, soul, and spirit should be freely given to God, which is our reasonable service. (b) Not only does God claim our love and devotion, but He has made us stewards of what we have in time, talent, and temporal goods. Since giving of our means to support the Lord's work is a scriptural injunction and an act of worship received and memorialized by our Lord, and since tithing antedates the Mosaic Law, was confirmed in the Law, and was approved by our Lord Jesus Christ, and since the New Testament clearly indicates that our giving is to be proportionate, believers are encouraged to adopt the system of tithing their income as a minimum expression of their stewardship. Our stewardship in material things is to be motivated by the spirit and example of our Lord who freely gave Himself for us all. Gen. 14:20, Mal. 3:8, 10; Matt. 23:23; Acts 4:32; 1 Cor. 16:2; 2 Cor. 8:9, 9:6-7. (Missionary Church Articles of Practice, n.d.)

\section{Summary}

In the past 20 years, research about philanthropy has taken an increased focus on the non-profit realm, specifically giving among members of Christian churches. Much of this research has focused on large, mainline denominations.

The literature in this chapter showed many themes related to the area of preaching and teaching on financial issues. Personal factors reviewed included fear, the need to be liked, education and training, the pastor's personal finances, and the pastor's knowledge of congregational giving. Social factors reviewed included materialism and consumerism, giving today compared to the 1920s, personal donor benefits, and the positive social influence on preaching on financial issues. Institutional factors reviewed 
included an overview of giving in America, triggers that increase giving levels such as gender, education, family income levels, free riding, religious involvement, and giving systems. Furthermore, an overview of popular church studies, Financial Peace University and Crown Ministries, was provided. The literature noted that both pastors and parishioners often reported being sensitive to money and finance discussions in the church.

With this study's focus on the small, evangelical denomination of the Missionary Church, this chapter also reviewed evangelical giving trends and the theological ideas and practices related to the Missionary Church. This summary included a look at the five theological traditions (Anabaptism, pietism, Wesleyan-holiness movement, Keswickianholiness movement, evangelicalism) that formed the Missionary Church.

This study attempted to add to previous studies by focusing on factors influencing pastoral preaching/teaching on financial issues in the small evangelical denomination of the Missionary Church. Chapter 3 will provide more information on the research design used for data collection and analysis to address the central questions raised by this study and informed by this literature review. 


\section{CHAPTER 3}

\section{METHODOLOGY}

\section{Introduction}

The purpose of this exploratory study was to examine the extent to which pastors within the Missionary Church preach on financially related issues. Additionally, this study investigated the extent to which selected demographic characteristics, personal, institutional (church), and social variables were related to the preaching of financially related issues.

This chapter describes the methodology used to address the research problem and questions of this exploratory study. Included in this section are the research questions, research design, population and sample, research instrumentation, research procedures, data analysis, and a summary.

\section{Research Questions}

Two questions were considered as a part of this study:

1. How many weekend messages does a pastor dedicate to preaching or teaching on a financially related topic in a year's time?

2. What are the demographic, personal, institutional, and social factors that influence pastors to preach and teach about financially related issues on a regular basis? 


\section{Research Design}

Because of the exploratory nature of this study and the desire to see how evangelical pastors in the Missionary Church compared to the overall literature available, a survey design was chosen as the best way to accomplish these objectives. Survey designs are procedures in quantitative research in which the investigator administers a questionnaire to groups of people to identify trends in attitudes, opinions, behaviors, or characteristics (Creswell, 2008).

There were several advantages to using a survey design for this study. First, the survey questions create a way to illicit a quick response on multiple topics including demographic areas, Likert-type responses, and Yes/No options for all various statements. Second, the survey provided immediate feedback for me to analyze. Third, a written survey was suited to provide a way for respondents to give confidential responses on fairly sensitive areas of finances and to protect participant anonymity. Fourth, because of the support of district superintendents and the denomination president, I was able to make a personal presentation of the study and give directions to respondents at scheduled district meetings. Because of the personal nature of the presentation, I was optimistic that high response rates were likely and that would improve data analysis of survey responses. The survey also promised to be more manageable for me and thus required minimal outside help or hired staff.

I realized I would face some disadvantages using a survey instrument. First, though a survey provided immediate feedback, it did not allow exploratory questioning to understand the meaning pastors gave to their questions. Second, the travel to all of the 
sites to collect data involved significant costs. Third, the written surveys would be subject to bias and coverage errors (Glasow, 2005, pp. 2-4).

Several practices were used to minimize the disadvantages and improve the study. First, because the Missionary Church was a small denomination with only 464 senior pastors in the United States and Puerto Rico, one way to increase response rates was for me to personally attend the district meetings where senior pastors meet. Second, although these personal visits added travel costs to collect data, the cost was absorbed as a part of my position at Bethel College, the only college of the Missionary Church denomination. Because someone from the college attends these district meetings to give a college update, I made those trips a part of my data collection process. Lastly, because I visited all districts, the full population of Missionary Church pastors in the United States and Puerto Rico was well sampled.

\section{Population and Sample}

The preaching/teaching pastor, in most cases known as the senior pastor, is the central leader within a church typically responsible for delivering weekend messages. In many ways, he is the face of a local congregation and, with the demise of Sunday School and mid-week Bible studies in many congregations, the prime source of delivering biblical knowledge to those who attend the church. The 464 senior pastors of the Missionary Church denomination for the United States and Puerto Rico were the focus of this study.

Table 1 gives a breakdown of the Missionary Churches by their district location, the number of churches in a district, and the total number of active, senior pastors. The 
districts serve as a way to divide the country into manageable areas to provide oversight for the various pastors and ministries.

Table 1

The Missionary Church-by District, District Office Location, Number of Churches, Number of Pastors, Number of Hispanic Churches, and Number of Hispanic Pastors

\begin{tabular}{|c|c|c|c|c|c|}
\hline \multirow{2}{*}{$\begin{array}{l}\text { District } \\
\text { Central }\end{array}$} & \multirow{2}{*}{$\begin{array}{l}\text { District Office } \\
\text { Fort Wayne, IN }\end{array}$} & \multicolumn{2}{|c|}{$\begin{array}{c}\text { Total } \\
\text { Churches /Pastors }\end{array}$} & \multicolumn{2}{|c|}{$\begin{array}{c}\text { Hispanic } \\
\text { Churches /Pastors }\end{array}$} \\
\hline & & 57 & 55 & 9 & 9 \\
\hline Central Texas & Fort Wayne, IN & 20 & 20 & 18 & 18 \\
\hline East Central & Troy, OH & 33 & 32 & & \\
\hline Eastern & New York, NY & 29 & 24 & 9 & 9 \\
\hline El Paso Mission & San Elizario, TX & 1 & 1 & 1 & 1 \\
\hline Florida & Sebring, FL & 13 & 13 & 7 & 7 \\
\hline Georgia/Alabama & Seymour, TN & 13 & 13 & 2 & 2 \\
\hline Hawaii & Waianae, HI & 18 & 18 & & \\
\hline Houston & Houston, TX & 10 & 10 & 9 & 9 \\
\hline Kentucky/Tenn & Seymour, TN & 7 & 7 & & \\
\hline Michigan & Burton, MI & 53 & 52 & 5 & 5 \\
\hline Mid-Atlantic & Fort Wayne, IN & 1 & 1 & & \\
\hline Midwest & Lincoln, NE & 17 & 17 & & \\
\hline New England & Saugus, MA & 8 & 8 & 8 & 8 \\
\hline North Central & Elkhart, IN & 69 & 69 & 8 & 8 \\
\hline North/South Carolina & Fort Wayne, IN & 14 & 14 & 1 & 1 \\
\hline Northwest & Yakima, WA & 15 & 15 & 3 & 3 \\
\hline Puerto Rico & San Juan, PR & 41 & 41 & 41 & 41 \\
\hline Rio Grande Valley & La Feria, TX & 7 & 7 & 7 & 7 \\
\hline \multirow[t]{2}{*}{ Western } & Moorpark, CA & 47 & 47 & 15 & 15 \\
\hline & & 473 & 464 & 142 & 142 \\
\hline
\end{tabular}

There were 473 total churches identified in the 2012 version of the Missionary Church Directory across the United States and Puerto Rico. Nine churches were without 
a pastor. Three hundred and fifteen of the 464 pastors participated in the study, giving a 67.9\% participation rate. Field (2005) reviewed many suggestions about the sample size necessary for a factor analysis study and concluded that it depended on many things. In general, over 300 cases was adequate.

\section{Research Instrumentation}

This section focuses on the instrumentation used for the research and gives a description of the instrument, discussing how it was developed, its validity and pilot study.

\section{Description}

The survey instrument used to gather data consisted of 43 questions focused on areas gleaned from the literature review. The survey instrument was translated into Spanish and English and was available to pastors in both languages. Fourteen of the questions specifically gathered demographic information. Thirteen of the questions sought responses on a pastor's personal views of their experience or given situation related to finances and stewardship issues. Eleven of the questions sought a pastor's views related to their institution (church) and/or congregational matters. Four questions sought the pastor's views on social perceptions about money and the church. Finally, one question asked a pastor to identify the number of weekends in a typical calendar year he completely dedicated to preaching or teaching on a financially related topic. The response to this last question served as the dependent variable in the study. The 14 demographic questions offered several response options designed to gather as many specific data as possible. The remaining questions, with the exception of three congregational questions, 
which sought a Yes or No response, were set in a Likert-type response of either Strongly Agree, Agree, Disagree or Strongly Disagree. The surveys used for the study can also be found in the appendixes. The English survey is Appendix A and Spanish survey is Appendix B. See Appendix C for a full description of each operational variable of the study. Appendix C includes the scoring used when data were collected and entered into the SPSS statistical software.

\section{Development}

While other survey instruments and results tables were reviewed as a part of this study (Hoge, Zech, McNamara, \& Donahue, 1996; Ronsvalle \& Ronsvalle, 1996), none were usable for this study. This study's central focus was the pastor. Other studies focused predominantly on congregational members as donors. Because this study was exploratory and interested in the Missionary Church’s pastor's views, the survey questions were specifically designed around issues of interest identified when conducting the literature review. Therefore, questions contained in the survey sought responses to areas such as a pastor's training in financial areas, the pastor's willingness to receive future training, the pressure a pastor felt to not preach on financial issues, and so forth.

When considering the demographic questions, many choices were given, for many of these questions allowed more detailed analysis. Again with the exploratory nature of the study in mind, I considered more answer options as information knowing I could always regroup if needed.

When considering the Likert-type responses, I chose to force the participant to choose one of the four responses as opposed to allowing an "Undecided" option, which would allow them an "easy way out or to not honestly respond to the question" (Patten, 
2001, p. 35). The downside to this approach was that a respondent might choose to intentionally skip a question (Glasow, 2005).

Because 142 of the 464 potential pastors were Hispanic (30.7\%; see Table 1), it was important for the study to have the survey instrument available in Spanish. I hired an outside, experienced individual to translate the survey instrument into Spanish. Once completed, that Spanish translation was then back-translated to the original English version by multiple reviewers.

\section{Validity}

An extensive review of the literature was performed. Most research in the area of philanthropy has been conducted in the period since 1990 when the Lilly Endowment provided funding for research on financial giving. Since that time most of the emphasis has been on the donor. While pastoral perspectives and financial giving were available through other research efforts (Hoge et al., 1996; Hoge et al., 1997; Hoge, Zech, McNamara, \& Donahue, 1999; S.L. Miller, 1999; Ronsvalle \& Ronsvalle, 1996; Smith et al., 2008; Wuthnow, 1999) little was known about the evangelical pastor.

When reviewing literature, there were several factors identified that may influence the extent to which a pastor might preach on financially related issues. These factors may be broadly categorized as "personal," "institutional” (related to the church), or social. The survey was designed to capture the views of pastors in the evangelical denomination known as the Missionary Church on those three areas: personal, institutional, and social.

In addition to 14 demographic questions, questions were asked if they were shown to be central in the literature review. For instance, in the area of personal 
considerations, question 19 on the survey was a question that asked the pastors their personal comfort level in preaching on financial issues. The background for this question came from several sources including Wuthnow (1999) who mentioned pastors tiptoe around such issues, Schulz (2001) who mentioned pastors fear teaching financial stewardship, and Bagwell’s (1993) description of a pastor's body language and posture when discussing such issues. Question 22 was another personal question that asked the pastor about the training he received during his education. Willmer was cited in Ronsvalle and Ronsvalle (1996) as mentioning that, historically, pastors were not trained; Mulder (1999) mentioned the lack of attention to financial matters in seminary curricula; and S.L. Miller (1999) mentioned that seminary leaders believed seminary was not the place to receive such training. These are two examples that demonstrate how questions were determined and the survey instrument built to gather the evangelically minded Missionary Church pastors’ perspectives on personal issues. A full review of supporting information for each personal question is found in Appendix D.

The same procedure was followed for institutional questions. For instance, question 30 on the survey asked the pastor to respond to a question related to "his church believed he talks too much about money.” The genesis for this question comes from Hoge et al. (1997), “you're always talking about money”; Ronsvalle and Ronsvalle (2006) mentioned that a pastor was allowed “one sermon per year” on a financial topic (typically giving); Ronsvalle and Ronsvalle’s (2006) example of a man walking out of the service whenever a pastor began a message on a financial issue; and Ronsvalle and Ronsvalle’s (1996) “we don’t talk about money in church.” Question 31 asked the pastor to respond to an increase in the church budget: Do they go toward outreach 
efforts? This question was based on Noll (2007) regarding the evangelical's desire to reach the lost, Ronsvalle and Ronsvalle (2006) noting the churches' failure to focus on others, Barna’s (2008) noting that evangelicals were more generous givers, and Ronsvalle and Ronsvalle’s (1999) finding that lack of vision affected giving. These are two examples of how questions were determined and the survey instrument built to glean the evangelically minded Missionary Church pastors' perspectives on institutional issues. A full review of supporting information for each personal question is found in Appendix D. Regarding the area of social issues, creating questions was handled in the same manner as the personal and institutional area. For example, survey question 41 asked the pastor if he believed consumer debt kept people from giving more generously. The basis for this question came from Ronsvalle and Ronsvalle (1996) who noted people were struggling financially, Russell (2002) who noted money was a god for many people, Wuthnow (1999) who mentioned pastors were aware of the pressures people felt to buy and purchase more, and stats on consumer debt provided by Woosley and Schulz (2011). Question 42 asked if the pastor believed clergy felt pressure to NOT speak on financially related topics. This question got its basis from Bagwell (1993) who noted people felt “whipped” and "guilty” and Wuthnow (1997) who mentioned families don’t even talk about money so why should the church? This process was used on most of the questions created in the survey. A full review of supporting information for each question is found in Appendix D.

Once the construction of the survey was completed, it was reviewed by my dissertation committee and by acquaintances familiar with both the Missionary Church and financial issues. It was then tested. 


\section{Pilot Study}

As suggested by Rudestam and Newton (2007), the survey instrument was

piloted. Three test cases were performed. The first took place on the campus of Bethel College. The second took place at The Chapel in Fort Wayne, Indiana. The pilot populations, in both cases, were students pursuing a Master of Ministry degree at Bethel College. These students came to the Bethel College campus once a month for 3 days of classes while pursuing their degree (or in the case of the Fort Wayne Group, they meet at The Chapel). In the pilot study, the group received instructions and then each student was given a survey packet including a consent form, survey, and a 9 x 12 envelope for their completed survey. The consent forms were collected once signed, and then participants took the survey. Once completed, the participants kept their survey until all were completed. A short discussion ensued to consider items that were unclear, confusing, or presented unforeseen questions or concerns. Following the discussion, participants placed their survey in the $9 \times 12$ envelope provided. Following these two sessions, feedback was shared with the dissertation committee with appropriate changes made to the survey instrument. A third and final pilot took place with eight members involved in leadership from the Missionary Church headquarters. Most of these participants had served as pastors earlier in their careers.

Rudestam and Newton (2007) noted that the reliability and validity of an instrument can be difficult to determine, and previous literature may be the only way to provide validation and reliability. As mentioned, a summary table of the variable and references is available in Appendix D showing the link to questions and literature. 


\section{Research Procedures}

A meeting with district superintendents from across the nation took place at the Missionary Church Headquarters in Fort Wayne, Indiana, in the summer of 2010. At this meeting I was given a chance to present the study and request permission for a few minutes at their annual district meetings to personally conduct the survey. They all agreed. Formal permission to perform the study was granted by the president of the Missionary Church, William “Bill” A. Hossler (see Appendix F).

Each district typically holds an annual meeting between October and June. I personally contacted each district superintendent to arrange to be on their meeting agenda sometime during their district conference meeting. It was determined that putting me on the agenda before a schedule break or meal would be best as those in attendance at the meetings could go right to break and those pastors participating in the survey could complete it at that time and then go to break. Once plans were finalized with the district superintendents, I made necessary travel arrangements.

Credentialed pastors of all churches in a given district were expected to attend these meetings but some were not able to for various reasons. This is often the case for bi-vocational pastors or those who have other job responsibilities. At these meetings, I was given an opportunity to talk to the whole assembly about the survey and promote the study prior to a scheduled break or meal. I shared with the pastors the purpose of the study, and I covered the instructions and the consent form and informed them of the time needed to complete the survey. Though not mandatory, I encouraged their participation because of the small size of the Missionary Church denomination and the potential population for the survey. Following my presentation, senior pastors where then given a 
chance to participate, at that moment, prior to taking their break. As the break began, pastors came forward and received a survey packet that contained either an English or Spanish version of the survey, an English or Spanish version of the consent form, and a 9 x 12 return envelope. Pastors signed the consent form and a designee from the conference collected those independent of me. Pastors then completed the survey, placed it in the $9 \mathrm{x}$ 12 envelope provided, sealed it, and returned it to me.

Once, the surveys were collected and I had left the district conference, I went through each survey and recorded the responses to match the operational definition I had set (see Appendix C).

Early in the data collection process, I worked to obtain participation from pastors who were unable to attend a given district conference. I worked with the district offices from the first five data gathering sites (Midwest, North/South Carolina, Florida, Puerto Rico, and the Eastern Region) to secure names and addresses of pastors who did not attend. To these pastors, I sent a cover letter, survey, consent form, a postage-paid, selfaddressed number 10 envelope for the consent form, and a self-addressed postage-paid 9 $\mathrm{x} 12$ envelope for the survey to be returned. The purpose behind the two separate envelopes was to protect a pastor's privacy. I received very few responses back. This helped confirm my original plan to do the survey at district meetings in person. I believe this decision helped to secure the highest level of participation.

\section{Data Analysis}

Three different types of analysis were performed on the data set entered in SPSS on the 315 respondents. These included descriptive statistics, exploratory factor analysis, and binary logistic regression. 


\section{Descriptive Statistics}

Frequency distributions for descriptive statistics were performed on the 14 demographic questions of the study. Descriptive statistics helped present the data in percentage categories to gain understanding of the study participants. Demographic variables included (a) district in which pastor was located, (b) pastor's age, (c) ethnicity, (d) marital status, (e) number of children at home, (f) years in ministry, (g) years as a preaching/teaching pastor, (h) currently full-time, part time, or bi-vocational, (i) years at current church, (j) current compensation package, (k) current church, average weekend attendance, (l) level of education, (m) degree from a Christian institution or seminary, (n) who handled finances in the pastor's home. Table 3 in Chapter 4 displays descriptive statistics for the demographic responses. Appendix E contains the frequency statistics of all other survey responses.

\section{Factor Analysis}

“Exploratory factor analysis is exploratory. It was designed and is still most appropriate for use in exploring a data set. It was not designed to test hypotheses or theories” (Costello \& Osborne, 2005, p. 8). “Factor analysis was a technique used to identify factors that statistically explained the variation and co-variation among measures” (Green \& Salkind, 2011, p. 313). In a nutshell, it is a data-reduction process. Rietveld and Van Hout (1993) noted factor analysis attempts to bring intercorrelated variables together under more general, underlying variables. More specifically, the goal of factor analysis was to reduce "the dimensionality of the original space and give an interpretation to the new space,” spanned by a reduced number of new dimensions which 
are supposed to underlie the old ones. In this process, factor extraction took place, meaning large numbers of variables were reduced to smaller numbers and regrouped.

\section{Sample Size}

Field (2005) reviewed many suggestions about the sample size necessary for a factor analysis study and concluded that it depends on many things. In general, over 300 cases is probably adequate but communalities after extraction should be above 0.5 . In SPSS a convenient option was offered to check whether the sample is big enough, the Kaiser-Meyer-Olkin measure of sampling adequacy (KMO-test). The sample was adequate if the value of KMO is greater than 0.5 (Field, 2000, p. 4). The sample size for this study was 315 and the KMO was .842, which is considered meritorious.

\section{Principal Component Analysis (PCA)}

The starting point of factor analysis is a correlation matrix, in which the intercorrelations between the studied variables were presented. The dimensionality of this matrix can be reduced by "looking for variables that correlate highly with a group of other variables, but correlated very badly with variables outside the group” (Field, 2000, p. 2). The process of producing this and other matrices typically hinges on using principle axis factoring (PAF) or principal components analysis (PCA), though there are other

options. SPSS offers six options including PAF, PCA, generalized least squares, maximum likelihood, alpha factoring, and image factoring.

According to Field (2000), strong feelings existed concerning the choice between PAF factor analysis and PCA. Costello and Osborne (2005) mentioned principal components analysis (PCA) became popular decades ago when computers were 
expensive and slow. Practically, however, the solutions generated in PCA differ little from those derived from other factor analysis techniques.

With the exploratory nature of the study, several tools were used with a variety of rotation methods producing several matrices. Three matrices were considered in a final analysis: (a) PCA with a pattern matrix using oblique rotation; (b) PAF with pattern matrix using oblique rotation; and (c) PCA with a rotated component matrix using varimax rotation. In the final analysis, option 1 provided two factors where the items meshed well and provided a coherent factor; thus, PCA with oblique rotation was used in this study.

\section{Rotation of Factors}

Field (2000) noted that after factor extraction it might be difficult to interpret and name the factors/components on the basis of their factor loadings. A solution for this difficulty was factor rotation. Factor rotation alters the pattern of the factor loadings, allowing for improved interpretation. Rotation can best be explained by imagining factors as axes in a graph, on which the original variables load. By rotating these axes, then, it is possible to make clusters of variables load optimally.

The two most common types of rotation methods are orthogonal and oblique. In orthogonal rotation there is no correlation between the extracted factors, whereas in oblique rotation there is. Orthogonal rotation is used when you believe your factors should be theoretically independent (unrelated to each other). Field (2005) suggested using oblique when you believe the factors should be related to each other. "In oblique rotation the results were a pattern matrix, structure matrix and a component correlation matrix. The pattern matrix represented the pattern loading (regression coefficients of the 
variable on each of the factors)" (as cited in Rietveld \& Van Hout, 1993, p. 281). Most

of the time pattern matrix is used to interpret factors. Bailey (1993) mentioned that "pattern matrix defined the simple structure configuration and was the basis for determining which factors represented which variables” (p. 92). Brauer (n.d.) noted that if rotation was oblique, the data were interpreted from the pattern matrix. The values in this matrix are partial correlations between the variables and the factors. Oblique rotation and pattern matrix were used in this exploratory study.

\section{Identifying Each Factor}

With respect to the correlation matrix, two things were important: The variables have to be intercorrelated, but they should not correlate too highly (Extreme multicollinearity and singularity) as this could cause difficulty in determining the unique contribution of the variables to the factor (Field, 2000, p. 444). Bartlett's test of sphericity was used to test for multicollinearity; in SPSS the determinant of greater than 0.00001 shows no multicollinearity (Field, 2000, p. 445).

Costello and Osborne (2005) mentioned that more common magnitudes in the social sciences were low to moderate communalities of .40 to .70 . If an item has a communality of less than .40 , it may either (a) not be related to the other items, or (b) suggest an additional factor that should be explored. Tabachnick and Fidell (2001) cite .32 as a good rule of thumb for the minimum loading of an item. Costello and Osborne (2005) note that a factor with fewer than three items was generally weak and unstable; five or more strongly loading items (.50 or better) were desirable and indicate a solid factor (p. 5). 


\section{Scree Plot}

Costello and Osborne (2005) found that the scree test involved examining the graph of the eigenvalues and looking for the natural bend or break in the data where the curve flattens out. The number of factors above the break (not including the point at which the break occurs) was usually the number of factors to retain (p. 3). Field (2005) mentioned the curve in the scree plot was difficult to interpret because the curve begins to tail off after three factors, but there is another drop-off after four factors before a stable plateau is reached. Therefore, we could probably justify retaining either two or four factors. Field (2005) notes the scree plot can be used when the sample size is large (around 300 or more cases). These criteria were applied to the data in this study.

\section{Naming and Defining Factors}

Once the analysis was run, communality level determined, and scree test reviewed, the factors were determined. Field (2005) voiced that once highly loading items have been grouped in the same factor, a process of identifying a theme for a factor must take place. He continued by saying that a factor with fewer than three items was generally weak and unstable and five or more strongly loaded items of .50 was desirable in indicating a solid factor. Two factors resulted and were labeled in this study using variables $\geq .50$. Factor 1 primary focus was on items related to the pastor and congregational financial training and church finances, and is thus given the theme:

Financial training and church finance. Factor 2 identified the pastor's beliefs on the tithe and stewardship as its theme and is thus the theme: Pastoral beliefs on giving and stewardship. 


\section{Reliability and Scale Scores}

Reliability comes to the forefront when variables developed from summated scales were used as predictor components in objective models. Since summated scales were an assembly of interrelated items designed to measure underlying constructs, it was very important to know whether the same set of items would elicit the same responses if re-administered (Santos, 1999). Tavakol and Dennick (2011) note that "internal consistency described the extent to which all the items in a test measure the same concept or construct and hence it was connected to the inter-relatedness of the items within the test” (p. 53). To accomplish this in EFA, Cronbach’s Alpha is used. Cronbach's Alpha is not a statistical test; it is a coefficient of reliability (or consistency).

Nunnaly (1978) has indicated 0.7 to be an acceptable reliability coefficient, but lower thresholds were sometimes used in literature. The following scales were observed: $\alpha \geq 0.9=$ Excellent; $0.8 \leq \alpha \geq 0.9=$ Good; $0.7 \leq \alpha \geq 0.8=$ Acceptable; $0.6 \leq \alpha \geq 0.7=$ Questionable; $0.5 \leq \alpha \geq 0.6=$ Poor; and $\alpha<0.5=$ Unacceptable. The Cronbach's Alpha for Factor I was .82, which was considered good. The Cronbach’s Alpha for Factor 2 was .63, which was considered acceptable.

\section{Binary Logistic Regression}

Binary logistic regression was performed using Factor 1 and Factor 2 and 11 of the 14 demographic variables. The three demographic variables excluded were the district, number of children, and who handles home finances. Because the demographic variables were categorical, it was appropriate to use logistic regression. Binary was 
chosen because the independent variables were compared to one of two dependent variable choices.

Three binary cases were explored: (a) pastor preached one or more times in a calendar year on a financially related topic or did not preach on financial topics at all; (b) pastor preached two or more times in a calendar year on a financially related topic or preached once or not at all; or (c) pastor preached three or more times in a calendar year on a financially related topic or preached twice or less. The second and third cases provided the most insightful results.

The Hosmer and Lemeshow Test was used to identify linear relationships between criterion and predictor variables. Since linear relations were being considered, Nagelkerke $R^{2}$ was used as the predictor of future outcomes. The regression models found Factor 1 (financial training and church finance), Factor 2 (pastor's beliefs on giving and stewardship), and years 10-19 of a pastor in ministry having significant partial effects in Case 2. These same variables appeared in Case 3 along with church attendance. When performing the restricted model in Case 3, the number of years in ministry variable was dropped from the model.

\section{Summary}

This chapter reviewed the methodology applied to this study. Presented were the research questions, research design, population and sample, research instrumentation (including its description, development, validity, and pilot study), research procedures, and data analysis procedures. The data analysis included descriptive statistics, exploratory factor analysis using PCA, and binary logistic regression. Results of the study are described in Chapter 4. 


\section{CHAPTER 4}

\section{RESULTS OF THE STUDY}

\section{Introduction}

The purpose of this exploratory study was to examine the extent to which pastors within the Missionary Church preach on financially related issues. Additionally, this study investigated the extent to which selected demographic characteristics, and personal, institutional (church), and social variables are related to the preaching of financially related issues. In this chapter, the demographic characteristics of the respondents are described, followed by analysis for the two research questions, and finally, a summary of the major findings.

The data were collected by using a survey instrument developed for this study to answer two research questions. First, in a year's time, how many weekend messages is a pastor inclined to completely dedicate to preaching or teaching on a financially related topic? Second, what are the demographic, personal, institutional, and social factors that influence pastors to preach and teach about financially related issues on a regular basis? The data were analyzed using descriptive statistics and exploratory factor analysis using principle component analysis (PCA) and binary logistic regression. 


\section{Demographic Characteristics of Respondents}

The demographic characteristics of the 315 respondents in this study are

displayed in Tables 2 and 3. Pastoral responses to the survey by Districts within the

Missionary Church are shown in Table 2. Of the total possible senior, preaching pastors in the denomination in $2012(N=464), 67.9 \%$ participated in the study. Discounting the Mid-Atlantic and El Paso Mission outlier, pastoral participation ranged from 14.3\% in the Kentucky/Tennessee District, to 100\% in the Georgia/Alabama District.

Table 2

Missionary Churches-Total District Pastors, Total Survey Participants by District, District Participation Percentage and District Survey Percentage

\begin{tabular}{|c|c|c|c|c|}
\hline District & $\begin{array}{l}\text { Total } \\
\text { District } \\
\text { Pastors }\end{array}$ & $\begin{array}{c}\text { Total } \\
\text { Survey } \\
\text { Participants }\end{array}$ & $\begin{array}{c}\% \\
\text { District } \\
\text { Participants }\end{array}$ & $\begin{array}{c}\% \\
\text { of Survey } \\
\text { Participants }\end{array}$ \\
\hline Central & 55 & 42 & 76.4 & 13.3 \\
\hline Central Texas & 20 & 5 & 25.0 & 1.6 \\
\hline East Central & 32 & 21 & 65.6 & 6.7 \\
\hline Eastern & 24 & 17 & 70.8 & 5.4 \\
\hline El Paso Mission & 1 & 0 & .0 & .0 \\
\hline Florida & 13 & 11 & 84.6 & 3.5 \\
\hline Georgia/Alabama & 13 & 13 & 100.0 & 4.1 \\
\hline Hawaii & 18 & 14 & 77.8 & 4.4 \\
\hline Houston & 10 & 7 & 70.0 & 2.2 \\
\hline Kentucky/Tenn & 7 & 1 & 14.3 & .3 \\
\hline Michigan & 52 & 43 & 82.7 & 13.7 \\
\hline Mid-Atlantic & 1 & 0 & .0 & .0 \\
\hline Midwest & 17 & 11 & 64.7 & 3.5 \\
\hline New England & 8 & 6 & 75.0 & 1.9 \\
\hline North Central & 69 & 49 & 71.0 & 15.6 \\
\hline North/South Carolina & 14 & 5 & 35.7 & 1.6 \\
\hline Northwest & 15 & 11 & 73.3 & 3.5 \\
\hline Puerto Rico & 41 & 28 & 68.3 & 8.9 \\
\hline Rio Grande Valley & 7 & 4 & 57.1 & 1.3 \\
\hline Western & 47 & 27 & 57.4 & 8.6 \\
\hline Totals & 464 & 315 & 67.9 & 100.0 \\
\hline
\end{tabular}


Table 3 displays the respondent’s demographics by age, race, marital status, children living at home, a pastor's total years in ministry, a pastor's total years as a preaching/teaching pastor, a pastor’s current work status, a pastor’s years preaching/teaching at his current church, pastor's compensation package, weekly church attendance at a pastor's church, pastor's level of education, pastor's college degree earned have a Christian emphasis or earned from a Christian college or seminary, and who handles the home finances.

Most of the respondents fell between the ages of 40 and 64 (71.8\%). Of the respondents, 64.1\% were White/Caucasian and 24.1\% were Hispanic/Latino. An overwhelming majority of the pastors are married (96.5\%) and 67\% have at least one child living at home.

Most of the participants surveyed have been in ministry in some capacity between 10 and 34 years (66.9\%) with slightly under $50 \%$ of pastors serving in a preaching/teaching capacity for less than 15 years. While there are part-time and bivocational pastors in the denomination, most pastors surveyed $(73.7 \%)$ work full-time in their churches with $63.5 \%$ of pastors serving at their current church for less than 10 years.

On compensation, 38\% of pastors indicated their total compensation package is under $\$ 30,000$, 36.2\% earn between $\$ 30,000$ - \$59,000, and $21.6 \%$ earn more than $\$ 60,000$ annually. With church attendance, 54.3\% of respondents noted they pastor churches with fewer than 100 people, while 32.3\% have weekly attendance between 
Table 3

Description of Respondents $(N=315)$

\begin{tabular}{|c|c|c|}
\hline Variable & $N$ & $\%$ \\
\hline \multicolumn{3}{|l|}{ Age } \\
\hline Less than 25 & 1 & .3 \\
\hline $25-29$ & 8 & 2.5 \\
\hline $30-34$ & 15 & 4.8 \\
\hline $35-39$ & 27 & 8.6 \\
\hline $40-44$ & 43 & 13.7 \\
\hline $45-49$ & 38 & 12.1 \\
\hline $50-54$ & 56 & 17.8 \\
\hline $55-59$ & 53 & 16.8 \\
\hline $60-64$ & 36 & 11.4 \\
\hline $65-69$ & 19 & 6.0 \\
\hline $70-74$ & 8 & 2.5 \\
\hline 75 and above & 4 & 1.3 \\
\hline Missing & 7 & \\
\hline \multicolumn{3}{|l|}{ Race } \\
\hline White/Caucasian & 202 & 64.1 \\
\hline Black/African American & 11 & 3.5 \\
\hline Asian/Pacific Islander & 14 & 4.4 \\
\hline Hispanic/Latino & 76 & 24.1 \\
\hline Other & 8 & 2.5 \\
\hline Missing & 4 & \\
\hline \multicolumn{3}{|l|}{ Marital Status } \\
\hline Married & 304 & 96.5 \\
\hline Widower & 1 & .3 \\
\hline Divorced & 3 & 1.0 \\
\hline Never Married & 5 & 1.6 \\
\hline Missing & 2 & \\
\hline \multicolumn{3}{|l|}{ Children Living at Home } \\
\hline None & 104 & 33.0 \\
\hline 1 child & 42 & 13.3 \\
\hline 2 children & 69 & 21.9 \\
\hline 3 children & 64 & 20.3 \\
\hline 4 children & 22 & 7.0 \\
\hline 5 or more & 11 & 3.5 \\
\hline Missing & 3 & \\
\hline
\end{tabular}


Table 3-Continued.

\begin{tabular}{|c|c|c|}
\hline Variable & $N$ & $\%$ \\
\hline \multicolumn{3}{|c|}{ Pastor's Total Years in Ministry } \\
\hline Less than 5 & 22 & 7.0 \\
\hline $5-9$ & 30 & 9.5 \\
\hline $10-14$ & 46 & 14.6 \\
\hline $15-19$ & 36 & 11.4 \\
\hline $20-24$ & 48 & 15.2 \\
\hline $25-29$ & 40 & 12.7 \\
\hline $30-34$ & 41 & 13.0 \\
\hline $35-39$ & 20 & 6.3 \\
\hline $40-44$ & 17 & 5.4 \\
\hline $45-49$ & 7 & 2.2 \\
\hline $50-54$ & 2 & .6 \\
\hline 55 and above & 1 & .3 \\
\hline Missing & 5 & \\
\hline \multicolumn{3}{|c|}{ Pastor's Total Years as a Preaching/Teaching Pastor } \\
\hline Less than 5 & 51 & 16.2 \\
\hline $5-9$ & 51 & 16.2 \\
\hline $10-14$ & 53 & 16.8 \\
\hline $15-19$ & 30 & 9.5 \\
\hline $20-24$ & 46 & 15.2 \\
\hline $25-29$ & 20 & 6.3 \\
\hline $30-34$ & 24 & 7.6 \\
\hline $35-39$ & 19 & 6.0 \\
\hline $40-44$ & 11 & 3.5 \\
\hline $45-49$ & 4 & 1.3 \\
\hline $50-54$ & 2 & .6 \\
\hline 55 and above & 0 & .0 \\
\hline Missing & 5 & \\
\hline \multicolumn{3}{|c|}{ Pastor's Current Status } \\
\hline Full-time & 232 & 73.7 \\
\hline Part-time & 18 & 5.7 \\
\hline Bi-vocational & 61 & 19.4 \\
\hline Missing & 4 & \\
\hline
\end{tabular}


Table 3-Continued.

\begin{tabular}{|c|c|c|}
\hline Variable & $N$ & $\%$ \\
\hline \multicolumn{3}{|c|}{ Pastor's Years Preaching/Teaching at Current Church } \\
\hline Less than 1 & 24 & 7.6 \\
\hline $1-2$ & 48 & 15.2 \\
\hline $3-5$ & 67 & 21.3 \\
\hline $6-9$ & 61 & 19.4 \\
\hline $10-14$ & 45 & 14.3 \\
\hline $15-19$ & 38 & 12.1 \\
\hline $20-24$ & 15 & 4.8 \\
\hline 25 and more & 16 & 5.1 \\
\hline Missing & 1 & \\
\hline \multicolumn{3}{|c|}{ Pastor's Compensation } \\
\hline Less than $10 \mathrm{~K}$ & 50 & 15.9 \\
\hline $10 \mathrm{~K}-19 \mathrm{~K}$ & 37 & 11.7 \\
\hline $20 \mathrm{~K}-29 \mathrm{~K}$ & 33 & 10.5 \\
\hline $30 \mathrm{~K}-39 \mathrm{~K}$ & 22 & 7.0 \\
\hline $40 \mathrm{~K}-49 \mathrm{~K}$ & 38 & 12.1 \\
\hline $50 \mathrm{~K}-59 \mathrm{~K}$ & 54 & 17.1 \\
\hline $60 \mathrm{~K}-69 \mathrm{~K}$ & 27 & 8.6 \\
\hline $70 \mathrm{~K}-79 \mathrm{~K}$ & 13 & 4.1 \\
\hline $80 \mathrm{~K}-89 \mathrm{~K}$ & 13 & 4.1 \\
\hline $90 K-99 K$ & 7 & 2.2 \\
\hline $100 \mathrm{~K}-109 \mathrm{~K}$ & 4 & 1.3 \\
\hline $110 \mathrm{~K}-119 \mathrm{~K}$ & 4 & .0 \\
\hline $120 \mathrm{~K}$ and above & 0 & 1.3 \\
\hline Missing & 13 & \\
\hline \multicolumn{3}{|c|}{ Weekly Attendance at a Pastor's Church } \\
\hline Less than 100 & 171 & 54.3 \\
\hline $100-149$ & 65 & 20.6 \\
\hline $150-249$ & 37 & 11.7 \\
\hline $250-499$ & 25 & 7.9 \\
\hline $500-749$ & 3 & 1.0 \\
\hline $750-999$ & 4 & 1.3 \\
\hline $1000-1499$ & 4 & 1.3 \\
\hline 1500 and above & 2 & .6 \\
\hline Missing & 4 & \\
\hline
\end{tabular}


Table 3-Continued.

\begin{tabular}{|c|c|c|}
\hline Variable & $N$ & $\%$ \\
\hline \multicolumn{3}{|c|}{ Pastor's Level of Education } \\
\hline High School & 39 & 12.4 \\
\hline 2 year/Assoc. & 41 & 13.0 \\
\hline 4 year Bach. & 109 & 34.6 \\
\hline Master’s & 103 & 32.7 \\
\hline $\mathrm{PhD}$ & 18 & 5.7 \\
\hline Missing & 5 & \\
\hline \multirow{2}{*}{\multicolumn{3}{|c|}{$\begin{array}{l}\text { Pastor's Degree Had a Christian Emphasis or Was } \\
\text { Earned from a Christian College or Seminary }\end{array}$}} \\
\hline & & \\
\hline Yes & 255 & 81.0 \\
\hline No & 53 & 16.8 \\
\hline Missing & 7 & \\
\hline \multicolumn{3}{|c|}{ Handles the Home Finances } \\
\hline Pastor & 124 & 39.4 \\
\hline Spouse & 84 & 26.7 \\
\hline Both share & 99 & 31.4 \\
\hline Someone else & 7 & 2.2 \\
\hline Missing & 1 & \\
\hline
\end{tabular}

$100-249$, and $12.1 \%$ have over 250 people weekly. In the area of education, $73 \%$ of pastors indicate their highest level of education is a bachelor's degree or above, noting $81 \%$ of pastors attended a college with a Christian emphasis or attained their degree from either a Christian college or seminary. Lastly, 39.4\% of pastors handle their home finances, whereas $31.4 \%$ of pastors and spouses share the responsibility. 


\section{Results by Research Questions}

\section{Research Question 1}

The first research question asked the pastor, How many weekend messages do you dedicate to preaching or teaching on a financial topic? Table 4 presents the results from this single survey question, showing few pastors in the Missionary Church do not preach on such topics (7.6\%). Many pastors preach and teach three or more times a year (43.5\%). Another 22.2\% preach twice a year, with $25.4 \%$ preaching or teaching one time annually. Overall, approximately $92 \%$ of pastors in the Missionary Church preach financially related topics at least once a year.

\section{Table 4}

Description of Respondents $(N=315)$ on How Many Weekend Messages a Pastor Completely Dedicates to Preaching/Teaching on a Financially Related Topic

\begin{tabular}{lcr}
\hline Number of Times & $N$ & $\%$ \\
\hline Never preach on a financial topic & 24 & 7.6 \\
1 time & 80 & 25.4 \\
2 times & 70 & 22.2 \\
3 times & 52 & 16.5 \\
4 times & 47 & 14.9 \\
5 times & 38 & 12.1 \\
Missing & 4 & \\
\end{tabular}




\section{Research Question 2}

The second research question asked, What are the demographic, personal, institutional, and social factors that influence pastors to preach and teach about financially related issues on a regular basis?

\section{Preliminary Analysis}

The survey instrument was designed to measure demographic, personal, institutional, and social variables that may influence the preaching and teaching on financially related issues. To determine if there is empirical support for these constructs, principle component analysis (PCA) was used. According to Field (2009), PCA is concerned with "establishing which linear components exist within the data and how a particular variable might contribute to that component” (p. 639). Once these linear components (called factors) were extracted, they were then rotated using both orthogonal and oblique procedures in order to derive more interpretable factor solutions. In orthogonal rotation, extracted factors are assumed to be uncorrelated. Orthogonal rotation is used when you believe your factors should be theoretically independent (unrelated to each other). Factors are assumed to be correlated when oblique rotations are used. Field (2005) suggested using oblique when you believe the factors should be related to each other. This was the case in this study and oblique rotations were used.

\section{Assumptions}

PCA requires that there are sufficient sample sizes and adequate item correlations in order for the data to be factorable. The sample size for this study was 315 respondents. In general, over 300 cases are usually considered adequate, but communalities after 
extraction should be above 0.5 (Field, 2005). In this study, the Kaiser-Meyer-Olkin (KMO) Measure of Sampling Adequacy was used, an inter-correlation matrix appropriate for factor analysis, and indicated a result of .842. Schwarz (2011) mentioned a desired 60 or higher is appropriate in order to proceed with factor analysis. In this sampling, 0.80 to 0.89 is considered meritorious, therefore, .842 was considered ideal for PCA and this study.

Bartlett's test of sphericity was used to test for multicollinearity. The results are displayed in Table 5. With respect to the correlation matrix, two things are important: The variables have to be intercorrelated, but they should not correlate too highly. Extreme multicollinearity and singularity could cause difficulty in determining the unique contribution of the variables to the factor (Field, 2000, p. 444). Bartlett's test in this study showed $\chi^{2}=915.73, d f=91, p=.000$, indicating that the original correlation matrix was not an identity matrix and, therefore, factor analysis was appropriate.

Table 5

Measure of Sample Adequacy Criterion

\begin{tabular}{lcccc}
\hline & & \multicolumn{3}{c}{ Bartlett's Test of Sphericity } \\
\cline { 3 - 5 } Analysis & Kaiser-Meyer-Olkin & Approx. Chi & $d f$ & Sig. \\
\hline Pattern & .842 & 915.73 & 91 & .000 \\
& & & & \\
\hline
\end{tabular}

Factor extraction and rotation

Several extraction methods were attempted to produce matrices that contained the most coherent data, but PCA produced the strongest loadings. Within this process, exploration included looking at as many as four factors using eigenvalue $>1$. A scree 
test was used to consider the "natural break" where the curve flattens out (Costello \& Osborne, 2005). Field (2005) mentions the scree plot can be used when the sample size was large (around 300 or more cases). The scree plot (see Figure 2) indicated two or three factors. In light of this, 3- and 2-factor solutions were then rotated using orthogonal (varimax) and oblique (oblinin) rotations. Factor rotation alters the pattern of the factor loadings allowing for improved interpretation. Field (2005) suggests using oblique when you believe the factors should be related to each other. This was the case in this study. The results of these procedures found that a 2-factor solution using oblique rotation resulted in the most interpretable and meaningful solution. Bailey (1993) mentions that "pattern matrix defines the simple structure configuration and is basic for determining which factors represent which variables” (p. 92).

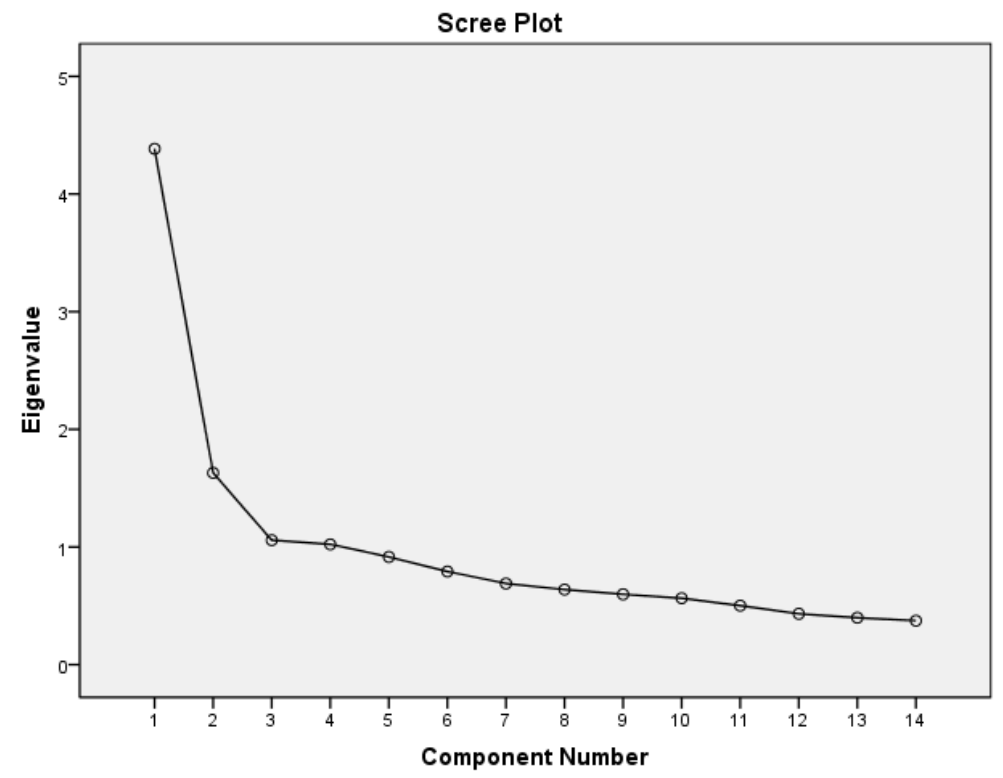

Figure 2. Scree plot for principle component analysis. 
Interpretation of the solutions

Costello and Osborne (2005) observed that low to moderate communalities of .40 to .70 are quite common in social sciences. If an item has a communality of less than .40, it may either (a) not be related to the other items, or (b) suggest an additional factor that should be explored. Tabachnick and Fidell (2001) suggest .32 as a good rule of thumb for the minimum loading of an item. Costello and Osborne (2005) note a factor with fewer than three items was generally weak and unstable; five or more strongly loading items (.50 or better) were desirable and indicate a solid factor (p. 5).

I examined a 2-factor solution. The 2-factor pattern matrix included 14 items with 13 items with loadings greater than .50. One item loaded in both Factor 1 and Factor 2 but the loading in each factor was less than .50. In examining the individual items, the cutoff of $>.50$ was determined for this study to result in the most interpretable factor solutions. Costello and Osborne (2005) suggested that items with loadings above .50 indicated a stronger and more solid factor. Because a sufficient number of items in Factor 1 and Factor 2 scored above .50, this determination provided for more robust factors. Factor 1 was comprised of 9 items with factor loadings $>.50$ defined by items related to pastoral financial training, church member financial training opportunities, and congregation financial areas. Factor 2 was comprised of four items with factor loadings $>$ .50 defined by items related to pastoral preaching and teaching beliefs about the tithe and Missionary Church doctrine. According to Costello and Osborne (2005), a factor is considered "solid" if there are at least five items loading above .50; less than three is considered weak. Factor 1 met this criterion with all nine items loading greater than .50 . 
Factor 2 had four strong items loading greater than .50. Table 6 represents the loadings for Factor 1 and Factor 2.

Table 6

Factor Model, Principle Component Analysis, and Pattern Matrix

\begin{tabular}{|c|c|c|c|}
\hline \multicolumn{4}{|c|}{ Survey } \\
\hline No. & Statement & 1 & 2 \\
\hline 26 & Being liked by congregation is important to pastor & .702 & \\
\hline 39 & Church offers financial training options other than & & \\
\hline & Crown Ministry or Financial Peace University & .696 & \\
\hline 31 & Annual increases in church budget address outreach efforts & .683 & \\
\hline 29 & Pastor knows giving records of congregation & .611 & \\
\hline 22 & $\begin{array}{l}\text { Received biblical financial training as part of } \\
\text { educational experience }\end{array}$ & .593 & \\
\hline 38 & Church offers Crown Financial Ministry study & .591 & \\
\hline 28 & Pastors should know giving records of their congregation & .574 & \\
\hline 23 & Received financial training since entering ministry & .519 & \\
\hline 24 & Pastor willing to attend future financial training & .508 & \\
\hline 32 & Annual increases in church budget address operations & $.367 \alpha$ & $.335 \alpha$ \\
\hline 20 & Pastor believes tithing still applicable for today’s Christian & & .806 \\
\hline 21 & Tithe is meant to come directly to the church & & .767 \\
\hline 36 & Pastor supports MC’s statement on stewardship & & .540 \\
\hline 19 & Pastor feels comfortable preaching on financial issues & & .534 \\
\hline
\end{tabular}

Note. Survey item $32(\alpha)$ meets Tabachnick and Fidell’s (2001) .32 minimum loading rule of thumb but missed the $\geq .50$ cutoff observed for this study. Because of the number of loadings $>.50$ a stronger, more robust factor was solidified by observing the stronger loading. Items with loadings less than 0.32 are not displayed in this table.

Field (2005) mentioned that once highly loading results have been grouped in the same factor, then a process of identifying a theme for a factor must take place. Factor 1's primary focus was on items related to the pastor's and congregation's financial training and church finances, and was thus given the theme: Financial training and church 
finance. Factor 2 identified the pastor's beliefs on the tithe and stewardship as its theme and was thus given the theme, Pastoral beliefs on giving and stewardship.

Reliability and scale scores

Tavakol and Dennick (2011) note that "internal consistency describes the extent to which all the items in a test measure the same concept or construct and hence it is connected to the inter-relatedness of the items within the test” (p. 53). To accomplish this, Cronbach’s Alpha was used. Cronbach’s Alpha is not a statistical test; it is a coefficient of reliability (or consistency). Nunnaly (1978) has indicated 0.7 to be an acceptable reliability coefficient, but lower thresholds were sometimes used in literature (as cited in Santos, 1999). The Cronbach’s Alpha for Factor 1 was .82, which was considered good. The Cronbach’s Alpha for Factor 2 was .63, which was considered acceptable.

See Table 7 for the Cronbach’s Alpha reliability estimates.

\section{Table 7}

Factor Analysis Descriptive Statistics and Cronbach's Alpha (CA) Reliability Statistics

\begin{tabular}{lrrrccc}
\hline Factor & $N$ & Mean & SD & Poss. Score & CA & CA Items \\
\hline 1 & 315 & 15.67 & 4.32 & $9-36$ & .816 & 9 \\
2 & 315 & 5.91 & 1.65 & $4-16$ & .629 & 4
\end{tabular}

Note. CA (Cronbach's Alpha) measures reliability. Factor 1, 10 items at .82 is considered good; Factor 2, 4 items at .63 is considered acceptable. 


\section{Research Question 2 Restated}

Based on work done with factor analysis (see preceding sections), question 2 was restated as follows: To what extent is preaching and teaching of financially related issues related to demographic characteristics, financial training/church finance, and pastoral beliefs on giving and stewardship?

To answer this question, three binary logistic regressions were employed. In Case 1 , the preaching and teaching of financially related issues were categorized as $0=$ never preach on financial topic, 1 = 1 or more times; in Case 2, preaching and teaching of financial issues were categorized as $0=0$ to 1 time, and $1=2$ or more times; and in Case 3 , preaching and teaching of financial issues were categorized as $0=0$ to 2 times, and $1=$ 3 or more times. Demographic characteristics, financial training/church finance, and pastoral beliefs on giving and stewardship were then regressed on to these categories of preaching and teaching of financially related issues.

Case 1: Preach once or more times annually vs. not at all

Table 8 shows the results of the binary logistic regression for Case 1. Regression coefficients, Wald statistics, $p$ value, and Odds-Ratio are shown. At $\alpha=0.05$, a test of the full model versus a model with intercept only was statistically significant, $\chi^{2}=$ 37.780, $d f=25, p=.049$. Thus, as a set, the demographic variables-financial training/church finance, and pastoral beliefs on giving and stewardship-were significantly related to the preaching and teaching of financially related issues. The model explained about 30\% (Nagelkerke $R^{2}=0.297$ ) of the variance in preaching/teaching of financially related topics. However, a closer examination of Table 
Table 8

Case 1: Full-Model, Variables in the Equation

\begin{tabular}{lrrrrrr}
\hline & B & \multicolumn{1}{c}{$S E$} & Wald & $d f$ & Sig. & Exp(B) \\
\hline ChristEd(1) & -.419 & .835 & .252 & 1 & .616 & .658 \\
Educationgroup & & & 4.531 & 2 & .104 & \\
Educationgroup(1) & -1.188 & .846 & 1.973 & 1 & .160 & .305 \\
Educationgroup(2) & .608 & .640 & .904 & 1 & .342 & 1.838 \\
Agegrp & & & 2.009 & 3 & .571 & \\
agegrp(1) & 1.329 & 1.145 & 1.348 & 1 & .246 & 3.779 \\
agegrp(2) & .121 & 1.134 & .014 & 1 & .907 & 1.129 \\
agegrp(3) & .395 & .852 & .215 & 1 & .643 & 1.484 \\
racegrp & & & 2.014 & 2 & .365 & \\
racegrp(1) & -1.045 & 1.398 & .559 & 1 & .455 & .352 \\
racegrp(2) & -1.912 & 1.467 & 1.699 & 1 & .192 & .148 \\
YrsMin & & & 5.670 & 3 & .129 & .170 \\
YrsMin(1) & -1.820 & 1.327 & 1.882 & 1 & .162 & .162 \\
YrsMin(2) & .419 & 1.275 & .108 & 1 & .742 & 1.521 \\
YrsMin(3) & -.226 & 1.208 & .035 & 1 & .851 & .797 \\
YrsPreach & & & 2.384 & 3 & .497 & \\
YrPreach(1) & .382 & 1.355 & .080 & 1 & .778 & 1.465 \\
YrsPreach(2) & 1.383 & 1.273 & 1.179 & 1 & .278 & 3.985 \\
YrsPreach(3) & 1.350 & 1.336 & 1.022 & 1 & .312 & 3.859 \\
yrsptpchurch & & & 2.456 & 2 & .293 & \\
yrsptpchurch(1) & .320 & .839 & .145 & 1 & .703 & 1.377 \\
yrsptpchurch(2) & 1.420 & .998 & 2.022 & 1 & .155 & 4.136 \\
ComperGrp & & & 1.502 & 3 & .682 & \\
CompenGrp(1) & .342 & 1.216 & .079 & 1 & .779 & 1.408 \\
CompenGrp(2) & .334 & 1.147 & .085 & 1 & .771 & 1.396 \\
CompenGrp(3) & -.651 & .803 & .656 & 1 & .418 & .522 \\
chattendgrp & & & .353 & 2 & .838 & \\
chattendgrp(1) & -.313 & 1.331 & .055 & 1 & .814 & .731 \\
chattendgrp(2) & -.590 & 1.268 & .216 & 1 & .642 & .555 \\
currstat_Rec(1) & .796 & .882 & .814 & 1 & .367 & 2.216 \\
marstat(1) & .741 & 1.525 & .236 & 1 & .627 & 2.097 \\
Fact1 & -.196 & .116 & 2.883 & 1 & .090 & .822 \\
Fact2 & -.195 & .165 & 1.403 & 1 & .236 & .823 \\
Constant & 6.705 & 2.801 & 5.731 & 1 & .017 & 816.354 \\
& & & & & & \\
\hline
\end{tabular}

Note. $\chi^{2}=37.780, d f=25, p=.049$, and Nagelkerke $R^{2}=0.297$. 
8 indicates that no single predictor variables are related to the preaching/teaching of financially related issues.

Case 2: Preach two or more times annually vs. once or not at all

The results of Case 2 in which the teaching/preaching of financially related topics is categorized as once/not at all and two or more times are shown in Table 9. The Hosmer and Lemeshow Test $\left(\chi^{2}=5.354, d f=8, p=.719\right)$ indicates a linear relationship between criterion and predictor variables. At $\alpha=0.05$, a test of the full model versus a model with intercept only was statistically significant, $\chi^{2}=71.348, d f=25, p<0.001$. The model explains about 31\% (Nagelkerke $R^{2}=0.307$ ) of the variance in teaching/preaching of financially related issues. Three variables appear to be significant predictors of teaching/preaching financially related topics: YrsMin(1), Factor 1, and Factor 2. To determine how well a model with only these three variables explains teaching/preaching of financially related topics, a second binary logistic regression was conducted. The result is reported in Table 10.

As expected, the model is statistically significant $\left(\chi^{2}=49.595, d f=5, p<0.001\right)$ and explains about 21\% (Nagelkerke $R^{2}=0.207$ ) of the variance in teaching/preaching of financially related topics. With negative regression coefficients, the result suggests that lower Factor 1 and Factor 2 scores are related to higher preaching/teaching scores. That is, those who had received financial training and believed in church finance ( $\mathrm{OR}=0.899)$ were 1.11 times more likely to preach/teach two or more times per year, and those who subscribe to church giving and stewardship $(\mathrm{OR}=0.739)$ are 1.36 times more likely to preach/teach financially related topics two or more times per year. The result also 
Table 9

Case 2: Full-Model, Variables in the Equation

\begin{tabular}{|c|c|c|c|c|c|c|}
\hline & B & $S E$ & Wald & $d f$ & Sig. & $\operatorname{Exp}(B)$ \\
\hline ChristEd(1) & .812 & .433 & 3.516 & 1 & .061 & 2.253 \\
\hline Educationgroup & & & .209 & 2 & .901 & \\
\hline Educationgroup(1) & .216 & .484 & .200 & 1 & .655 & 1.242 \\
\hline Educationgroup(2) & .100 & .352 & .081 & 1 & .776 & 1.105 \\
\hline Agegrp & & & 4.338 & 3 & .227 & \\
\hline agegrp(1) & 1.126 & .611 & 3.402 & 1 & .065 & 3.084 \\
\hline agegrp(2) & .525 & .523 & 1.009 & 1 & .315 & 1.691 \\
\hline agegrp(3) & .736 & .453 & 2.642 & 1 & .104 & 2.087 \\
\hline racegrp & & & .197 & 2 & .906 & \\
\hline racegrp(1) & -.167 & .600 & .078 & 1 & .781 & .846 \\
\hline racegrp(2) & -.295 & .666 & .196 & 1 & .658 & .745 \\
\hline YrsMin & & & 7.077 & 3 & .069 & \\
\hline YrsMin(1) & -1.648 & .725 & 5.162 & 1 & $.023 *$ & .192 \\
\hline $\operatorname{YrsMin}(2)$ & -.406 & .600 & .457 & 1 & .499 & .666 \\
\hline YrsMin(3) & -.250 & .544 & .212 & 1 & .645 & .779 \\
\hline YrsPreach & & & 1.992 & 3 & .574 & \\
\hline YrPreach(1) & .178 & .698 & .065 & 1 & .779 & 1.195 \\
\hline YrsPreach(2) & .694 & .659 & 1.111 & 1 & .292 & 2.002 \\
\hline YrsPreach(3) & .164 & .633 & .067 & 1 & .796 & 1.178 \\
\hline yrsptpchurch & & & .196 & 2 & .906 & \\
\hline yrsptpchurch(1) & -.016 & .467 & .001 & 1 & .972 & .984 \\
\hline yrsptpchurch(2) & .137 & .477 & .083 & 1 & .773 & 1.147 \\
\hline ComperGrp & & & 1.062 & 3 & .786 & \\
\hline CompenGrp(1) & .465 & .652 & .507 & 1 & .476 & 1.591 \\
\hline CompenGrp(2) & .586 & .616 & .905 & 1 & .342 & 1.796 \\
\hline CompenGrp(3) & .390 & .454 & .739 & 1 & .390 & 1.477 \\
\hline chattendgrp & & & 3.844 & 2 & .146 & \\
\hline chattendgrp(1) & -1.199 & .636 & 3.551 & 1 & .060 & .301 \\
\hline chattendgrp(2) & -1.108 & .595 & 3.471 & 1 & .062 & .330 \\
\hline currstat_Rec(1) & .370 & .451 & .675 & 1 & .411 & 1.448 \\
\hline marstat(1) & .002 & .986 & .000 & 1 & .998 & 1.002 \\
\hline Fact1 & -.139 & .060 & 5.367 & 1 & $.021^{*}$ & .871 \\
\hline Fact2 & -.347 & .104 & 11.403 & 1 & $.001^{*}$ & .707 \\
\hline Constant & 4.409 & 1.463 & 9.087 & 1 & .003 & 82.179 \\
\hline
\end{tabular}

* indicates a $p$ value $<.05$. 
Table 10

Case 2: Restricted Model, Variables in the Equation

\begin{tabular}{lrrrrlr}
\hline & B & SE & Wald & $d f$ & Sig. & Exp(B) \\
& & & & & & \\
YrsMin & & & 14.117 & 3 & $.003^{*}$ & \\
YrsMin(1) & -1.119 & .397 & 7.955 & 1 & $.005^{*}$ & .326 \\
YrsMin(2) & .280 & .361 & .601 & 1 & .438 & 1.323 \\
YrsMin(3) & .151 & .352 & .186 & 1 & .667 & 1.164 \\
Fact1 & -.107 & .037 & 8.235 & 1 & $.004^{*}$ & .899 \\
Fact2 & -.302 & .088 & 11.828 & 1 & $.001^{*}$ & .739 \\
Constant & 4.320 & .722 & 35.827 & 1 & .000 & 75.200 \\
& & & & & & \\
\hline
\end{tabular}

Note. $\chi^{2}=49.595, d f=5, p<0.001$, and Nagelkerke $R^{2}=0.207$.

$*$ indicates a $p$ value $<.05$.

Table 11

Case 2: Crosstabulation for Years in Ministry, Preaching Two or More Times

\begin{tabular}{|c|c|c|c|c|c|}
\hline & & & \multicolumn{2}{|c|}{ preach2 } & \multirow[b]{2}{*}{ Total } \\
\hline & & & $0-1$ & 2 or more & \\
\hline \multirow{8}{*}{$\begin{array}{l}\text { YrsMin: } \\
\text { Years in the } \\
\text { Ministry }\end{array}$} & $<10$ & Count & 29 & 22 & 51 \\
\hline & & \% w/in YrsMin & $56.9 \%$ & $43.1 \%$ & $100.0 \%$ \\
\hline & $10-19$ & Count & 22 & 60 & 82 \\
\hline & & \% w/in YrsMin & $26.8 \%$ & $73.2 \%$ & $100.0 \%$ \\
\hline & $20-29$ & Count & 26 & 62 & 88 \\
\hline & & \% w/in YrsMin & $29.5 \%$ & $70.5 \%$ & $100.0 \%$ \\
\hline & $30+$ & Count & 27 & 59 & 86 \\
\hline & & \% w/in YrsMin & $31.4 \%$ & $68.6 \%$ & $100.0 \%$ \\
\hline
\end{tabular}

Note. Pearson Chi-Square $=14.821 ; d f=3 ; p=.002$. 
indicates that, compared to those who had been in the ministry $30+$ years, those who had been in the ministry less than 10 years were more likely to preach/teach financially related issues only 0-1 times a year. Indeed, the cross-tabulation in Table 11 shows that when considered together with Factor 1 and Factor 2, 56.9\% of those who had been in the ministry less than 10 years preach/teach financially related topics 0-1 time per year, whereas only $31.4 \%$ of those who had been in the ministry $30+$ years preach/teach it $0-1$ time/year.

Case 3: Preach three or more times annually vs. two or less

The results of Case 3 in which the teaching/preaching of financially related topics is categorized as three or more times annually or two or less times annually are shown in Table 12. The Hosmer and Lemeshow Test $\left(\chi^{2}=2.611, d f=8, p=.956\right)$ indicates a linear relationship between criterion and predictor variables. At $\alpha=0.05$, a test of the full model versus a model with intercept only was statistically significant, $\chi^{2}=73.551, d f=$ 25, $p<0.001$. The model explains about 31\% (Nagelkerke $R^{2}=0.308$ ) of the variance in teaching/preaching of financially related issues. Six variables appear to be significant predictors of teaching/preaching financially related topics: YrsMin(1), chattendgrp, chattendgrp (1), chattendgrp (2), Factor 1, and Factor 2. To determine how well a model with only these six variables explains teaching/preaching of financially related topics, a second binary logistic regression was conducted. The result is reported in Table 13.

As expected, the model is statistically significant $\left(\chi^{2}=43.549, d f=4, p<0.001\right)$ and explains about $18 \%$ (Nagelkerke $R^{2}=0.183$ ) of the variance in teaching/preaching of financially related topics. With negative regression coefficients, the result suggests that 
Table 12

Case 3: Full-Model, Variables in the Equation

\begin{tabular}{|c|c|c|c|c|c|c|}
\hline & $\mathrm{B}$ & $S E$ & Wald & $d f$ & Sig. & $\operatorname{Exp}(B)$ \\
\hline ChristEd(1) & .728 & .428 & 2.886 & 1 & .089 & 2.070 \\
\hline Educationgroup & & & 3.162 & 2 & .206 & \\
\hline Educationgroup(1) & .037 & .452 & .007 & 1 & .935 & 1.038 \\
\hline Educationgroup(2) & -.542 & .346 & 2.453 & 1 & .117 & .582 \\
\hline Agegrp & & & 3.034 & 3 & .386 & \\
\hline agegrp(1) & 1.045 & .609 & 2.943 & 1 & .086 & 2.845 \\
\hline agegrp(2) & .636 & .514 & 1.529 & 1 & .216 & 1.889 \\
\hline agegrp(3) & .354 & .438 & .654 & 1 & .419 & 1.425 \\
\hline racegrp & & & .126 & 2 & .939 & \\
\hline racegrp(1) & -.159 & .545 & .085 & 1 & .771 & .853 \\
\hline racegrp(2) & -.016 & .626 & .001 & 1 & .979 & .984 \\
\hline YrsMin & & & 6.243 & 3 & .100 & \\
\hline YrsMin(1) & -1.494 & .706 & 4.472 & 1 & $.034^{*}$ & .225 \\
\hline $\operatorname{YrsMin}(2)$ & -.663 & .573 & 1.338 & 1 & .247 & .515 \\
\hline YrsMin(3) & .010 & .499 & .000 & 1 & .985 & 1.010 \\
\hline YrsPreach & & & 2.985 & 3 & .394 & \\
\hline YrPreach(1) & -.197 & .674 & .086 & 1 & .770 & .821 \\
\hline YrsPreach(2) & -.193 & .623 & .096 & 1 & .756 & .824 \\
\hline YrsPreach(3) & -.827 & .585 & 2.000 & 1 & .157 & .437 \\
\hline yrsptpchurch & & & 2.460 & 2 & .292 & \\
\hline yrsptpchurch(1) & .112 & .450 & .062 & 1 & .803 & 1.119 \\
\hline yrsptpchurch(2) & .575 & .448 & 1.646 & 1 & .200 & 1.778 \\
\hline ComperGrp & & & 3.769 & 3 & .288 & \\
\hline CompenGrp(1) & .943 & .644 & 2.144 & 1 & .143 & 2.568 \\
\hline CompenGrp(2) & 1.159 & .602 & 3.704 & 1 & .054 & 3.185 \\
\hline CompenGrp(3) & .473 & .465 & 1.034 & 1 & .309 & 1.605 \\
\hline chattendgrp & & & 8.428 & 2 & $.015^{*}$ & \\
\hline chattendgrp(1) & -1.649 & .570 & 8.363 & 1 & $.004^{*}$ & .192 \\
\hline chattendgrp(2) & -1.237 & .513 & 5.815 & 1 & $.016^{*}$ & .290 \\
\hline currstat_Rec(1) & .027 & .424 & .004 & 1 & .949 & 1.028 \\
\hline $\operatorname{marstat}(1)$ & .289 & 1.020 & .080 & 1 & .777 & 1.335 \\
\hline Fact1 & -.127 & .055 & 5.344 & 1 & $.021 *$ & .880 \\
\hline Fact2 & -.308 & .108 & 8.117 & 1 & $.004^{*}$ & .735 \\
\hline Constant & 3.507 & 1.406 & 6.218 & 1 & .013 & 33.350 \\
\hline
\end{tabular}

Note. $\chi^{2}=73.551, d f=25, p<0.001$, and Nagelkerke $R^{2}=0.308$.

$*$ indicates a $p$ value $<.05$. 
Table 13

Case 3: Restricted Model, Variables in the Equation

\begin{tabular}{lrrrrrr}
\hline & B & SE & Wald & $d f$ & Sig. & Exp(B) \\
\cline { 3 - 4 } & & & & & & \\
chattendgrp & & & 6.757 & 2 & $.034^{*}$ & \\
chattendgrp(1) & -1.275 & .491 & 6.741 & 1 & $.009^{*}$ & .279 \\
Fact1 & -1.072 & .507 & 4.473 & 1 & $.034^{*}$ & .342 \\
Fact2 & -.121 & .037 & 10.753 & 1 & $.001^{*}$ & .886 \\
Constant & -.276 & .087 & 10.111 & 1 & $.001^{*}$ & .759 \\
& 5.388 & .837 & 41.417 & 1 & .000 & 218.867 \\
\hline
\end{tabular}

Note. $\chi^{2}=43.549, d f=4, p<0.001$, and Nagelkerke $R^{2}=0.183$.

$*$ indicates a $p$ value $<.05$.

Table 14

Case 3: Crosstabulation for Church Attendance, Preaching Three or More Times

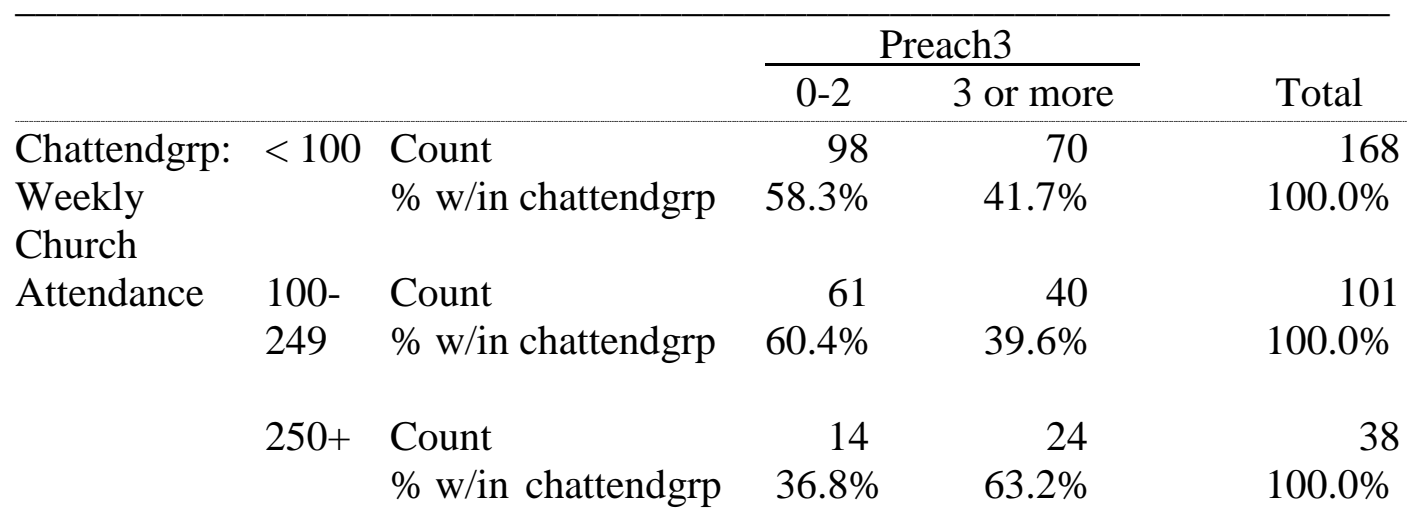

Note. Pearson Chi-Square $=6.820 ; d f=2 ; p=.033$.

lower Factor 1 and Factor 2 scores are related to higher preaching/teaching scores. That is, those who had received financial training and believed in church finance $(\mathrm{OR}=0.886)$ were 1.13 times more likely to preach/teach 3 or more times per year, and those who 
subscribe to church giving and stewardship $(\mathrm{OR}=0.759)$ are 1.36 times more likely to preach/teach financially related topics 3 or more times per year. Relative to larger churches (250+), pastors of smaller churches are more likely to preach 2 or less times a year on financially related topics. A cross tabulation (see Table 14) indicates that when considered with Factor 1 and Factor 2, about $60 \%$ of pastors in medium and smaller churches preach 2 or less times per year compared to about 37\% of pastors in large (250+) churches.

\section{Summary of Major Findings}

This exploratory survey study was designed to examine independent variables from demographic, personal, institutional (church), and social characteristics that influence pastors within the Missionary Church, Inc., to preach and teach on financially related issues. Though variables within their own category did not show correlation, there are significant findings in the study. The following are four major findings of this study:

First, over $92 \%$ of pastors in the Missionary Church preach about financially related topics at least once a year. Of those who do, $43.5 \%$ preach three or more times, $22.2 \%$ preach twice annually, and $25.4 \%$ preach one time annually.

Second, through factor analysis, two factors were identified and shown to be primary predictors of preaching/teaching on financially related topics. Factor 1 had a theme of financial training and church finance. Factor 2 had a theme of pastoral beliefs on giving and stewardship. The loadings of these factors are significant when compared to existing literature in this field of study.

Third, when considered together with Factor 1 (financial training/church finance) and Factor 2 (pastoral beliefs on giving and stewardship), pastors who have been in 
ministry over 10 years are more inclined to preach/teach on financially related topics two or more times annually (10-19 years/73.2\%) compared to pastors who have been in ministry for less than 10 years (43.1\%).

Fourth, when considered together with Factor 1 (financial training/church finance) and Factor 2 (pastoral beliefs on giving and stewardship), pastors in congregations of larger churches $(250+)$ were more inclined to preach on financially related topics three or more times a year as compared to those in congregations of smaller size.

These findings will be discussed in Chapter 5. 


\section{CHAPTER 5}

\section{SUMMARY, DISCUSSION, AND RECOMMENDATIONS}

\section{Introduction}

This chapter presents a summary of this study designed to explore preaching and teaching on financially related topics among pastors in the Missionary Church denomination. It reviews the study context, problem, purpose, research questions, and research design, and summarizes key findings. It also discusses the implications of the research for Missionary Church pastors, leaders, and future researchers.

\section{Context of the Study}

Smith et al. (2008) estimate an extra \$46 billion could be available if committed Christians gave $10 \%$ of their after-tax income instead of the current $1-3 \%$. That figure rises to $\$ 85$ billion when considering other offerings.

Tithing is just one example of a financial topic taught in the Bible. In fact, the Bible is full of instruction on a variety of financial matters. There are roughly 500 verses explicitly on prayer, less than 500 verses on faith, but more than 2,350 verses on money and possessions (Dayton, 1996). Fifteen percent of everything Christ said dealt with financial topics, more than his teachings on heaven and hell combined (Alcorn, 2001). Sixteen of the 38 parables Jesus presented centered on how to handle money and possessions. The Bible discusses many financial issues such as investing, wealth, taxes, 
debt, honesty, contentment, cosigning, inheritance, working, compensation, and giving. If the Bible speaks to financial areas as much or more than any other topic, and if Jesus Christ emphasized His teaching using financial illustrations, one would expect financial topics to be a major teaching area within Christian churches. According to Smith et al. (2008), this does not appear to be the case:

Prior research has shown that very many pastors and priests are uncomfortable in communicating with the members of their congregations about their responsibility to give money generously. Clergy discomfort with talking about and training for handling money is a well-established fact and a mere 7 percent were satisfied with the seminary training of financial issues. (p. 72)

Furthermore, John Ronsvalle and Sylvia Ronsvalle (as cited in Hoge et al., 1997) noted only $6 \%$ of pastors answered favorably the statement: Most pastors enjoy preaching about money.

Other studies (Hoge et al., 1997; S.L. Miller, 1999; Mulder, 1999; Ronsvalle \& Ronsvalle, 1996) suggested that one reason for the reluctance on the part of pastors could be their lack of training in addressing financial issues. However, minimal research has examined the factors predicting pastors' teaching on financial issues. Understanding these factors may help pastors learn how to improve biblical teaching on financial principles, which may help church members grow in personal knowledge and understanding of biblical financial concepts. This exploratory study attempted to fill this gap in research within a small, evangelical setting.

\section{Statement of the Problem}

Little is known about how much time and focus pastors in evangelical settings give to finances in their preaching and teaching ministry to parishioners. Even less is known about these issues in smaller evangelical denominations. Still, less is known about 
the pastoral factors that might influence or predict preaching and teaching on financial matters. The problem this study addressed was exploring demographic, personal, institutional, and/or social variables that influence pastors in the Missionary Church to speak on financial themes.

\section{Purpose}

The purpose of this exploratory study was to examine the extent to which pastors within the Missionary Church preached on financially related issues. Additionally, this study investigated the extent to which selected demographic characteristics, and personal, institutional (church), and social variables were related to the frequency of this preaching on financially related issues. The study examined factors in the context of the Missionary Church denomination using a survey design of senior, preaching/teaching pastors.

\section{Research Questions}

Two questions were considered as a part of this study:

1. How many weekend messages does a pastor dedicate to preaching or teaching on a financially related topic in a year's time?

2. To what extent is preaching and teaching of financially related issues related to demographic characteristics, financial training/church finance, and pastoral beliefs on giving and stewardship?

\section{Research Design and Procedures}

A survey design was chosen as the best way to explore variables identified to study in the research. A complete list of the variables and their source of validity can be found in Appendix C and Appendix D. 
The survey instrument consisted of 43 questions focused on perspectives gleaned from the literature review. Fourteen of the questions specifically gathered demographic information. Thirteen of the questions sought responses on a pastor's views of their own personal experience or given situation related to finances. Eleven of the questions sought a pastor's views related to their institution (church) and/or congregational matters. Four of the questions sought the pastor's views on social issues related to finances. Finally, one question asked a pastor to identify the number of weekends in a typical calendar year he dedicates completely to preaching or teaching on a financially related topic; the response to this question served as the dependent variable in the study. The survey questions provided quick response choices for demographic areas, and Likert-type responses and Yes/No options for all others.

Because 142 of the 464 potential pastors (30.6 \%) in the Missionary Church were Hispanic/Latino, it was important for the study to have a Spanish version of the survey instrument. A translator was hired to create that survey from the English version. Once completed, that Spanish translation was then translated back to be compared to the original created survey. This helped to improve the reliability between the two instruments. See Appendix A for the English version instrument of the survey and Appendix B for the Spanish version.

Because the Missionary Church is a small denomination with only 464 potential senior pastors in the United States and Puerto Rico, it was determined that the best way to have the highest potential response rate would be for me to attend the annual district meetings and survey the pastors in person. For oversight purposes, the Missionary Church was divided into districts across the United States and Puerto Rico. These 
districts hold annual meetings which require pastor participation. Fifteen sites were visited between October 2011 and June 2012 to collect data.

At each district meeting prior to a scheduled break or meal, I shared with the pastors the purpose of the study and covered the instructions for the survey and consent form. Though not mandatory, I encouraged their participation because of the small size of the Missionary Church denomination. As the scheduled break began, participating pastors came forward, received a survey packet that contained an English or Spanish survey, an English or Spanish consent form, and a 9 x 12 envelope. Once pastors signed the consent form, it was collected by a conference designee independent of the survey. Pastors then completed the survey, placed it in the $9 \times 12$ envelope, sealed it, and returned it to a designated place. Once, the surveys were collected and I had left the district conference, I went through each survey, scored the responses to match the operational definition established for the SPSS software, and then entered the data. (See Appendix C for operational definitions.)

The purpose for visiting each of these district meetings was to gather as high a participation rate as possible in an effort to negate non-response bias in the study. Three hundred and fifteen of the 464 pastors participated in the study (67.9\%). Field (2005) reviewed many suggestions about the sample size necessary for a factor analysis study and concluded, in general, that over 300 cases is an adequate number.

\section{Data Analysis}

The data were analyzed using three different methods. First, descriptive statistics was used to analyze the 14 demographic questions on the survey (see Table 3 in Chapter 4). Of the total possible senior, preaching pastors in the denomination in $2012(N=464)$, 
67.9\% participated in the study. Discounting the Mid-Atlantic and El Paso Mission outliers, pastoral participation ranged from $14.3 \%$ in the Kentucky/Tennessee District to $100 \%$ in the Georgia/Alabama District. Most of the respondents fell between the ages of 40 and 64 (71.8\%). Of the respondents, 64.1\% were White/Caucasian and 24.1\% were Hispanic/Latino. An overwhelming majority of the pastors were married (96.5\%) and $67 \%$ had at least one child living at home.

Most of the participants surveyed had been in ministry in some capacity between 10 and 34 years (66.9\%) with slightly under $50 \%$ of pastors serving in a preaching/teaching capacity for less than 15 years. While there were part-time and bivocational pastors in the denomination, most pastors (73.7\%) worked full-time in their churches with $63.5 \%$ of pastors serving at their current church for less than 10 years.

In the areas of compensation, church attendance, pastoral education, and pastoral home finances, the following data were recorded: Thirty-eight percent of pastors indicated their total compensation package is under $\$ 30,000$, 36.8\% earn between $\$ 30,000-\$ 59,000$, and $21.6 \%$ earn more than $\$ 60,000$ annually. Over half of the pastors surveyed have churches with fewer than 100 people (54.3\%), whereas 32.3\% have weekly attendance between $100-249$, and $12.1 \%$ have over 250 people weekly. In the area of education, 73\% of pastors indicate their highest level of education is a bachelor's degree or above, noting $81 \%$ of pastors attended a college with a Christian emphasis or attained their degree from either a Christian college or seminary. Lastly, 39.4\% of pastors handle their home finances, while $31.4 \%$ of pastors and spouses share the responsibility.

Second, to determine if there was empirical support for the personal, institutional, and social constructs of the study, exploratory factor analysis was performed on the 28 
independent variables. "Factor analysis was not designed to test hypotheses or theories" (Costello \& Osborne, 2005, p. 8). "Factor analysis is a technique used to identify factors that statistically explained the variation and co-variation among measures” (Green \& Salkind, 2011, p. 313). In a nutshell, it is a data-reduction process. Rietveld and Van Hout (1993) noted factor analysis attempts to bring intercorrelated variables together under more general, underlying variables.

Principal Component Analysis (PCA) was chosen as the extraction method using oblique rotation and pattern matrix. I examined a two-factor solution using a scree plot (see Figure 2) to analyze a breakpoint. The two-factor pattern matrix included 14 factors with 13 items of loadings greater than .50. One loading appeared in both Factor 1 and Factor 2 but the loading score of that variable on each factor was less than .50. In examining the individual items, a cutoff of $>.50$ was administered in this study to identify significant factor coefficients. Factor 1 was comprised of nine items $>.50$ with concentrations related to pastoral financial training, church member financial training opportunities, and congregation financial areas. It was given the theme Financial training and church finance. Factor 2 was comprised of four items $>.50$ relating to pastoral beliefs about the tithe and Missionary Church doctrine. The theme Pastoral beliefs on giving and stewardship was given to Factor 2.

According to Costello and Osborne (2005), a factor was considered "solid” if there are at least five items loading above .50; less than three is considered weak. Factor 1 met this criteria with all nine items loading greater than .50. Factor 2 has four strong items loading greater than .50. The Kaiser-Meyer-Olkin (KMO) Measure of Sampling Adequacy indicated an inter-correlation matrix appropriate for factor analysis $(\mathrm{KMO}=$ 
$.842>.50)$. Bartlett's test of sphericity was used to test for multicollinearity $\left(X^{2}=\right.$ 915.73, $d f=91, p=.000$ ). The Cronbach's Alpha (not a statistical test but a coefficient of reliability/consistency) for Factor 1 was .82, which is considered good. The Cronbach’s Alpha for Factor 2 was .63, which is considered acceptable. The descriptive statistics for Factors 1 and 2 in the study were as follows: In both cases, $N=315$. Mean for Factor I = 15.67 with a $S D$ of 4.32. Possible score range for Factor 1 was 9-36. Mean for Factor $2=5.91$ with a $S D$ of 1.65. Possible score range for Factor 2 was 4-16. Scoring on the survey instrument ranged from Strongly Agree $=1$ to Strongly Disagree $=$ 4. Given the way these responses were coded, low to high, a lower score (toward Strongly Agree) corresponded to a higher likelihood of preaching more on financially related topics, which will be seen in the logistic regression model summary to follow. Inversely the same is true, a pastor higher on the scoring scale (toward strongly disagree) is less likely to preach on financially related topics. Understanding this, pastors who scored low on areas of training and church finance (Factor 1) were more likely to preach on financially related topics. Also, pastors who scored low on beliefs toward giving and the Missionary Churches Statement on stewardship (Factor 2) were more likely to preach on financially related issues.

The third method used to analyze the data was binary logistic regression analysis using .05 criterion for statistical significance. Three cases were explored using the following as dependent variables: (a) pastor preached one or more times in a calendar year on a financially related topic or did not preach on financial topics at all (Case 1); (b) pastor preached two or more times in a calendar year on a financially related topic or preached once or not at all (Case 2); or (c) pastor preached three or more times in a 
calendar year on a financially related topic or preached twice or less (Case 3). The first case showed no significant variables likely because there was too small a sample of those pastors who never preach on financially related issues in a calendar year's time. The second and third cases provided insightful results.

In Case 2, a full model was constructed identifying (a) a pastor in years 10-19 of ministry $/ p=.023$; (b) Factor $1 / p=.021$, and (c) Factor $2 / p=.001$ as significant variables. A restricted model of significant variables and crosstabulations with years in ministry and the dependent variable were conducted. The Omnibus Test of Model Coefficients showed $X^{2}=49.595 ; d f=5 ; p=.000$ and The Nagelkerke $R^{2}$ of .207 indicates $21 \%$ of the variance in preaching and teaching on a financially related topic can be explained by the regression model. The Hosmer and Lemeshow Test $\left(X^{2}=9.774 ; d f=8 ; p=.281\right)$ indicated a linear relationship between criterion and predictor variables. The crosstabulations $\left(X^{2}=14.821 ; d f=3 ; p=.002\right)$ indicated $73 \%$ of the pastors in years $10-19$ of ministry preached on financially related topics two or more times; $71 \%$ of the pastors in years 20-29 of ministry preached on financially related topics two or more times; and $69 \%$ of the pastors in at least their $30^{\text {th }}$ year of ministry preached on financially related topics two or more times. This compared to $43 \%$ of those with less than 10 years of ministry experience were likely to preach on financially related issues two or more times annually.

In Case 3, a full model was constructed identifying (a) a pastor in years 10-19 of ministry $/ p=.034$; (b) Factor $1 / p=.021$, and (c) Factor $2 / p=.004$ as significant variables but also added church attendance groups: chattendgrp $(<100) / p=.015$; chattendgrp(1)(100-249) $p=.004$; chattendgrp(2)(250+)/p $=.016$. A restricted model of 
significant variables was conducted. The Omnibus Test of Model Coefficients showed $X^{2}=43.549 ; d f=4 ; p=.000$ and The Nagelkerke $R^{2}$ of .183 indicated $18 \%$ of the variance in preaching and teaching on a financially related topic can be explained by the regression model. The Hosmer and Lemeshow Test $\left(X^{2}=2.220 ; d f=8 ; p=.974\right)$ indicated a linear relationship between criterion and predictor variables. Of importance, the restricted model dropped the years in ministry as a variable in the restricted model, implying a more experienced pastor in terms of years in ministry was likely preaching in churches of $250+$ people.

\section{Major Findings}

The following represent the four major findings of this exploratory study of pastors in the Missionary Church denomination:

1. Over $92 \%$ of pastors in the Missionary Church preach about financially related topics at least once a year; $43.5 \%$ preach three or more times, $22.2 \%$ preach twice annually, and $25.4 \%$ preach one time annually.

2. Through factor analysis, two factors were identified and shown to be primary predictors of preaching/teaching on financially related topics. Factor 1 had a theme of financial training and church finance. Factor 2 had a theme of pastoral beliefs on giving and stewardship. The loadings of these factors are significant when compared to existing literature in this field of study.

3. When considered together with Factor 1 (financial training/church finance) and Factor 2 (pastoral beliefs on giving and stewardship), pastors who have been in ministry over 10 years are more inclined to preach/teach on financially related topics two or more 
times annually (10-19 years/73.2\%) compared to pastors who have been in ministry for less than 10 years $(43.1 \%)$.

4. When considered together with Factor 1 (financial training/church finance) and Factor 2 (pastoral beliefs on giving and stewardship), pastors in congregations of larger churches $(250+)$ were more inclined to preach on financially related topics three or more times a year as compared to those in congregations of smaller size.

\section{Discussion}

This section interprets each of the findings, relating them to the research questions and also to applicable literature.

\section{Finding One}

The majority of pastors (92.4\%) dedicated at least one weekend message a year to a financially related topic with $43.5 \%$ preaching three or more times, $22.2 \%$ preaching twice annually, and $25.4 \%$ preaching one weekend message annually. I considered it a surprising finding that two thirds of Missionary Church pastors preached at least twice a year on a financially related topic. I think this is significant given previous studies would have led me to believe most pastors would spend a maximum of only one weekend preaching on such issues. It is further surprising given that previous studies report parishioners’ limited approval to hear such messages.

Mead (1998) noted pastors were excoriated for preaching too much about money because people want to avoid the subject and its hold on them. S.L. Miller (1999) noted that pastors in her study were permitted only one standard message per year. My experience as a lifelong church attender would interpret this one standard message as the 
annual sermon on tithing or message about giving. Ronsvalle and Ronsvalle (1996) told of one pastor being counseled in his first interview with the congregational leadership board that the congregation expected one money sermon per year. Another story mentioned by Ronsvalle and Ronsvalle (1996) tells of a congregational leader who made a special effort to inform the pastor that he had given a fine sermon—except that it belonged in September, not in the spring. In other words, in this church we talk about money only one time a year and that is in the fall. Mead (1998) argued that clergy seem to be told to restrict their talking about finances to "a little" when it comes to talking about church budgets and contributions to the church, but when it came to talking about people’s personal budgets, this was off limits. "Something has to give! Both in talking with clergy about what they say and from examining the transcripts of their sermons, we must say that clergy often tiptoed around the topic of money as if they were taking a walk through a mine field” (Wuthnow, 1999, p. 147). Additionally, Mead (1998) spoke of pastors feeling uncomfortable with a fall stewardship campaign, and Bagwell (1993) mentioned the body language and posture of a pastor exhibited how uncomfortable it was to preach on these topics.

Because of the five theological traditions that undergird the Missionary Church value personal faith commitment including stewardship, I had reason to believe that the Missionary Church pastor would preach at least one weekend message annually and probably in the area of giving. I was surprised to see how many addressed financial issues twice and three times annually. Knowing the literature on this sensitive issue, I anticipated much less than the findings showed. Once or less would have been more in line with Mead (1998), Ronsvalle and Ronsvalle (1996), and Wuthnow (1999). Even 
more surprising than the number of times a pastor dedicated weekend messages was their attitude. Eighty-eight percent of Missionary Church pastors responded Strongly Agree or Agree to the question, I feel comfortable preaching/teaching on financially related topics.

This finding differed from many researchers. For example, Hoge et al. (1997) mentioned one fear felt by nearly every pastor was fear of criticism, “You’re always talking about money.” Hoge et al. (1997) further commented that for the vast majority of pastors, this criticism was unfair as most pastors go to great lengths to avoid talking about money because they know how sensitive and potentially alienating it is. Stowell (1987) wrote of a situation many pastors would welcome: Instead of allowing their pastor to apologize for preaching on money, two members reproved a pastor's apology after the service saying, “Giving is a privilege and act of worship.” There was no need to apologize (p. 23).

As noted above, the Missionary Church’s more conservative, literal biblical perspective may help explain this finding and why it differs on this topic from prior studies. Other studies were predominantly performed in large, mainline denominations. The Missionary Church’s conservative, evangelical teachings and emphasis often focus on personal stewardship, on the benefits of stewardship, and the joy that can come from biblically handling one’s finances. Noll (2007) mentioned that the evangelical religion was a religion of the person engaged with the Bible and "to lose that engagement would be to lose something essential” (p. 25). Given the amount of financially related content in the Bible, it would be appropriate for a pastor who is trained and pastoring within the Missionary Church to be educated and challenged to understand such topics or issues and 
feel called and obligated to teach them to others. Willmer (1995) also contributed important insights into the evangelical mind-set in noting:

Four main reasons help provide an understanding of the theological underpinnings of the evangelical faith. The first is the distinct tie to the Gospel and the desire to reach people who do not know Jesus Christ; second, is the desire to preserve the nation; third, is a moral and spiritual responsibility to avoid the material and maintain a Godcentered worldview and fourth, is a response to biblical stewardship. (pp. 107-108)

The high response of pastors to biblical themes of financial stewardship may also be linked to Willmer's first suggestion of reaching people with the gospel. As the name implies, the Missionary Church has a strong culture of missionary activity, which is funded through financial contributions. Being receptive to biblical stewardship creates an openness to personal involvement in remembering and actively participating in reaching the world with the gospel. While the world often considers evangelicals extremists, Noll (2007), again, described evangelicals as people engaged in the Bible. It seemed logical that regular preaching and teaching on financially related topics such as generous giving would go hand in hand for people "engaged in the Bible."

Finally, a possible connection may exist between preaching more often on financial topics and more generous giving. Barna's (2008) and Smith et al.’s (2008) studies show evangelicals to be among the most generous of givers. I suggest that one of the reasons evangelicals are documented as being more generous contributors may be that sermons are being presented in a more regular manner in evangelical church settings. Because of this, people are challenged on a more regular basis to consider stewardship in their daily lives. This notion would support recent work by Starks and Smith (2013) who report on their work with American Catholics. They note:

In our analysis, we find that the single most important factor explaining giving gaps is a lack of "spiritual engagement with money" on the part of most American Catholics. 
Rather than seeing their use of money and possessions as a part of their spiritual life-as a part of Christian formation and faithfulness-American Catholics tend to compartmentalize: they tend to separate money from matters of faith and to think that money and material possessions have little to do with spiritual or religious issues. Catholics who do engage with money as a spiritual matter and who see their money as ultimately God's, however, are much more financially generous, reducing the Catholic giving gap almost entirely. (p. 3)

The idea of preaching regularly on such topics is one way of integrating the spiritual life and keeping people from compartmentalizing finances. If my findings here about the regularity of preaching in the Missionary Church have been true for decades, it could be that this might give some explanation for the higher giving rates within the Missionary Church. Table 15 shows five decades of per-capita giving among many denominations. The Missionary Church has regularly been among the top percentage givers, which could be a result of parishioners regularly seeing a connection between their personal spiritual walk and their finances. Starks and Smith (2013) found that "spiritually engaging with money, recognizing that how one uses money and possessions is an important part of one's spiritual journey, was associated with much more generous giving” (p. 22).

\section{Finding Two}

Through factor analysis, two factors were identified and shown to be primary predictors of preaching/teaching on financially related topics. Factor 1 had a theme of financial training and church finance. Factor 2 had a theme of pastoral beliefs on giving and stewardship. These factors, and the loadings represented, were also surprising for as in the first finding, the results of these respondents were quite different from existing literature. 
Table 15

Missionary Church Historical Giving

\begin{tabular}{lcccc}
\hline Year & $\begin{array}{c}\text { \# Denom. } \\
\text { Reporting }\end{array}$ & $\begin{array}{l}\text { MC } \\
\text { Rank }\end{array}$ & $\begin{array}{c}\text { \$ Per } \\
\text { Capita }\end{array}$ & Top Per Capita Denomination \\
\hline 1973 & 42 & 3 & 340.09 & Berean Fund. Church -429.19 \\
1983 & 45 & 1 & 783.59 & Missionary Church -783.59 \\
1993 & 35 & 3 & 1291.66 & Allegheny Wes. Meth -1846.94 \\
2003 & 62 & 3 & 2011.09 & Allegheny Wes. Meth -2687.10 \\
2012 & 63 & 7 & 2309.42 & Allegheny Wes. Meth -3662.12
\end{tabular}

Note. Data in line 1 are from Yearbook of American and Canadian Churches 1973 (pp. 242-243), by C. H. Jacquet, Jr., 1973, Nashville, TN: Abingdon Press. Data in line 2 are from Yearbook of American and Canadian Churches 1983 (pp. 244-245), by C. H. Jacquet, Jr., 1983, Nashville, TN: Abingdon Press. Data in line 3 are from Yearbook of American and Canadian Churches 1993 (pp. 257-258), by K. Bedell, 1993, Nashville, TN: Abingdon Press. Data in line 4 are from Yearbook of American and Canadian Churches 2003 (pp. 382-387), by E. W. Lindner, 2003, Nashville, TN: Abingdon Press. Data in line 5 are from Yearbook of American and Canadian Churches 2012 (pp. 382387), by E. W. Lindner, 2003, Nashville, TN: Abingdon Press.

First, one finding in this study revealed $88 \%$ of the pastors responded Strongly agree or Agree to "I am comfortable preaching/teaching on financially related topics.” This was in contrast to Smith et al. (2008) who noted prior research has shown that very many pastors and priests were uncomfortable in communicating with the members of their congregations about their responsibility to give money generously. Clergy discomfort with talking about and training for handling money is a well-established fact. Furthermore, John Ronsvalle and Sylvia Ronsvalle (as cited in Hoge et al., 1997) stated that only $6 \%$ of pastors answered favorably the statement: Most pastors enjoy preaching about money. This was a significant difference. 
Second, 53\% of the pastors surveyed responded Strongly agree or Agree to "I received biblical financial training as a part of my educational experience.” Smith et al. (2008) mentioned that a number of clergy talked about having relatively little to no training or education about money in their pastoral preparation. One pastor explained, “It’s not something you do in seminary, at least we didn't” (p. 106). This was also a significant difference. The data analysis noted $81 \%$ of Missionary Church pastors attained their degree in a field with Christian emphasis or attended a Christian College. It could be that attending Christian colleges may have given them more exposure to training in the Missionary Church than was reported in other studies where clergy came from more varied denominations with more diverse educational backgrounds.

Third, only $11 \%$ of pastors responded Strongly agree or Agree to "I feel pressure in my church to not talk about money." Smith et al. (2008) noted pastors also spoke frequently and unhappily about the pressure they feel from the congregations to not talk too much about money (p. 103). Missionary Church pastors did not respond as feeling this pressure. This was another significant difference between my study and other studies and could be attributed to the evangelical pastor in the Missionary Church denomination. If the pastor values a personal faith commitment including stewardship, then he would not exclude what might be considered sensitive topics just because he might "step on someone's toes." If topics or biblical principles of any nature were important for the overall spiritual growth of the church member, then it would be worthy of addressing. Financial principles would be such topics since they are so prevalent in the biblical text. Fourth, $60 \%$ of pastors mentioned their church offers Crown Financial Study, Financial Peace University, or some other form of financial study, and $26 \%$ of churches 
offer two options. The Alban Institute and Lake Institute on Faith \& Giving study (2009) showed $27.7 \%$ of their surveyed churches $(N=1,517)$ offered classes or events on personal finance or giving. The concern for individuals' and families’ financial wellbeing and the emphasis on missions may provide a social context that supports and encourages pastors in my study to speak more about financial training as a part of church ministry.

Fifth, Kluth (1998) mentioned 90\% of churches have no active plan for teaching biblical financial principles to their congregations (CSA seminar research). This study showed $60 \%$ reported offering financial training opportunities to their congregation. However, the last two decades since Kluth’s study have seen a rise in financial training opportunities within churches. The Alban Institute and Lake Institute on Faith and Giving (2009) reported $27.7 \%$ of churches engaging in such opportunities. That being said, the Missionary Church appears to be more actively promoting financial training for congregational members than do other denominations studied to date.

Sixth, 79\% of pastors responded Strongly agree or Agree to "I received biblical financial training since entering the ministry.” Furthermore, in a separate survey question, 90\% of pastors responded Strongly agree or Agree to "I am willing to attend biblical financial training in the future.” These two responses identify another difference from previous research. Consider the following: Willmer noted "pastors were not trained, so they seldom knew what to say and (when they do know) were afraid to say it” (as cited in Ronsvalle \& Ronsvalle, 1996, p. 129). Kluth (1998) mentioned 85\% of pastors felt unequipped and uncomfortable teaching on finances and giving (Lilly Foundation Studies). In a survey conducted by S.L. Miller (1999), less than 15\% said they were 
satisfied or very satisfied with the administrative and financial training they received. S.L. Miller (1999) also noted that only 15\% of Protestants and 14\% of Catholic clergy said they were interested in future financial resource management training. These numbers identify two extremes in pastoral views. The large, mainline denomination pastor appears frustrated, uninterested, and simply unwilling to engage this area. The Missionary Church pastor, however, seems open to future learning. I believe this suggests a further link to a willingness to speak to and address financial issues and aligns well to the evangelical's personal faith journey, which is supported by the theological practices of the Missionary Church and may be true of other evangelical denominations.

Factor 2, with the theme of pastoral beliefs on giving and stewardship, also provided some new findings which lend support to the Smith et al. (2008) work. In Smith et al.'s (2008) second condition they noted that

if Christian congregations confidently taught the normative instructions of their faith tradition regarding generous financial giving, generous giving would also be increased by Christian leaders' strongly encouraging believers to make theologically informed, principled decisions about and commitments to generous financial giving. (p. 97)

Consider the following three responses from my survey: (a) 97\% of pastors responded Strongly agree or Agree to “I believe tithing is still applicable for today’s Christian”; (b) 93\% responded Strongly agree or Agree to "I believe the tithe is meant to come directly to the church," and (c) 99\% of pastors responded Strongly agree or Agree to "I support the Missionary Church’s statement on stewardship.”

These types of responses, along with the other differences shared, could be along the lines of what Smith et al. (2008) were encouraging when they suggest Christian congregations confidently teach their faith traditions. Again, Noll (2007) described the 
evangelical as engaged in the Bible. If the Bible is held in such high regard, then so would preaching on all of its contents regardless of the subject matter. Biblical stewardship and topics of finances are often mentioned within the Bible and appear to be addressed by the Missionary Church pastor.

These responses from my results were quite different from the literature and were explained, I believe, by the difference of the evangelical mind-set of the Missionary Church. Erdel (1997) mentioned there were five theological traditions that have guided the Missionary Church (Anabaptism, pietism, Wesleyan-holiness movement, Keswickian-holiness movement, evangelicalism). These strong traditions emphasized personal commitment and sacrifice, which often were exhibited through personal giving. That belief included a commitment to honor God with one's finances as a steward of one’s possessions, recognizing God as the true owner.

Pastors in the Missionary Church set the tone in the denomination by the fact that $95 \%$ of senior pastors tithe or give above and beyond the $10 \%$ level. The example of pastoral tithing commitment supports the Smith et al. (2008) notion of congregations maintaining high expectations by honoring generous giving and the importance of building accountability and congregational trust. The pastor "practicing what he preaches” helps build this trust. It may also provide the platform to be able to preach about such topics on a regular basis as he knows he is not asking others to do that which he is not already doing as well.

As an expert in this field, Hoge (1994) suggested "three factors were foremost as reasons” why evangelicals may contribute at a higher level than other Christian groups. First, evangelicals were involved in their churches, and church involvement is the 
strongest, single predictor of giving. Second, evangelicals hold to strong beliefs in biblical truths, which is another strong predictor of giving. Third, evangelicals disproportionately considered religion important in their lives; again, a predictor of giving. The second and third examples from Hoge (1994) strongly attest to the focus of a life lived by biblical principles. It would be my conviction that effectively teaching biblical principles would be a top priority of a Missionary Church pastor. Hoge (1994, 1995) further mentioned all studies indicated that strong personal faith was associated with higher contributions. The evangelical's faith also included belief in God's promise that God will take care of the faithful, and it gives higher priority to a spiritual life than the material life (as cited in Noll, 2007, p. 12).

In a final thought, Noll’s (2007) work noted that generous funding of para-church organizations was the jewel in the crown of evangelical philanthropy. With sacrificial fund-raising efforts for evangelical para-church agencies, evangelical gospel proclamation and evangelical good works have displayed a flexibility, urgency, adaptability, and mobility that have accomplished marvels. He continued by saying that evangelicals were faithful funders of missionaries.

\section{Finding Three}

When considered together with Factor 1 (financial training/church finance) and Factor 2 (pastoral beliefs on giving and stewardship), pastors who have been in ministry over 10 years are more inclined to preach/teach on financially related topics two or more times annually (10-19 years/73.2\%) compared to pastors who have been in ministry for less than 10 years (43.1\%). 
Hoge et al. (1997) called this subject "sensitive and potentially alienating.” So, why would someone in their early years of ministry be less inclined to preach multiple times annually on financially related issues as compared to someone with at least 10 years' experience? There are several potential explanations for these data. One of those reasons, as Hoge mentioned, is alienating oneself. Hoge et al. (1997) noted many pastors want to be liked by their church members, and they feel they would be alienating members if they pushed too hard on money issues. The top loading item of Factor 1 in my study was "Being liked by my congregation is important to me.” This supports Hoge et al.’s (1997) research although nearly 15 years separate the two studies. Moreover, Hoge et al. (1997) further wrote that most pastors are loved and respected, but they all hoped to avoid situations in which they risk losing the love and respect of their parishioners. This need to be loved is probably all the more sensitive for someone in their early years when they were establishing their ministry. As a person who has attended church his whole life, I can see how a pastor, a young or less expereinced pastor, would be more concerned about building and securing relationships as a part of building his personal ministry. It is hard to build those if one feels he will actually separate people by addressing certain topics.

Smith et al. (2008) pointed to a second common consideration. Many pastors stated that they were personally uncomfortable talking with parishioners about giving money because of the direct implications of their own income. "It is like I am raising my own salary” (p. 105). Fifty-five percent of respondents in my survey led churches of less than 100 people and another 33\% of pastors led churches between 100-249 people. A young or inexperienced pastor would likely be serving in a smaller church, making valid 
this concept that their salary and benefits amounted to a good portion of the overall budget. Speaking too often about finances could appear self-serving.

Another real consideration centers around the pastor's own ability to handle personal finances. Ronsvalle and Ronsvalle (1996) noted a national denomination executive believed that many pastors have never been trained to handle money, so they have trouble handling their personal finances. That thought grows in significance when considering ministerial staff often try to survive on marginal incomes. Given this combination of factors, a pastor might find it difficult to speak about financial responsibility to his congregation when he cannot balance his own checkbook. This could be further intensified by the fact that $38 \%$ of pastors in the Missionary Church were compensated at less than $\$ 29 \mathrm{~K}$ annually with another 7\% earning between $\$ 30-39 \mathrm{~K}$. Depending on the size of the pastor's family and other income sources, some of these pastors' families would be only a few thousand dollars above the poverty line. A young pastor would likely fall into one of these salary categories providing tight financial margins. If they found they were struggling financially, this could place a barrier in preaching on financially related topics from an "integrity” standpoint. In other words, “How can I preach on that which I cannot do myself?”

A fourth potential reason why a younger or inexperienced pastor may be less inclined to preach as often on financial issues is his own struggle with personal giving. One could understand, for instance, why a pastor would not want to preach or teach on giving if he was not giving. Hoge et al. (1997) also expressed concern about how their family’s financial circumstances, including their own giving to the church, impacted their ability to talk about money, as well as how their message was received by church 
members. It would appear hypocritical to implore the congregation to do that which the pastor is not. It would probably even be convicting. Allen (2005) said several people in his survey noted that sermons on stewardship were more credible when worshippers could perceive that the preacher lived with integrity. Though this option was a real possibility, my survey revealed 95\% of pastors in the Missionary Church personally tithe or give above the $10 \%$ level, leaving this potential reason as unlikely. Nonetheless, it is still a possibility.

Lastly, Wilhelm et al. (2007) affirmed less giving and less attendance by baby boomers were indicators of declining generosity. Their study further expressed that results provided evidence that generational change was at the foundation of recent changes in American religious giving and religious involvement. Ronsvalle and Ronsvalle (1996) referred to a report going back as far 1972 that concluded, “As people see it, the main thing blocking church support simply was a surprising urge for more affluent living. . . . Rival attractions seemed to be gaining more of the religious dollar” (p. 35). "Pastors were also keenly aware of the pressures that encourage church members to spend money on material possessions even to the point of going heavily into debt. They were overwhelmed by these issues” (Wuthnow, 1999, p. 71).

My study disclosed 11\% of my survey respondents were under the age of 35 . These pastors may be learning how to do effective ministry while at the same time learning life's many lessons. They would have always dealt with the issue of materialism, consumer debt, and the accumulation of "things." It certainly could be intimidating to speak often about financial matters or even giving. It appeared safer to speak the traditional one-time-a-year sermon or not at all and avoid the charge that all the church 
cares about is money (Schulz, 2001). That being said, the young pastor needs to

understand the importance of teaching on these issues. Wuthnow (1999) recorded that

one third of those who heard a sermon in the last year said they also thought a great deal in the past year about what the Bible teaches concerning money and about the relationship between religious values and their personal finances. Ninety-two percent of those who had thought a great deal about the relationship between religious values and their finances agreed that the Bible contains valuable teaching about money. And the Bible is the guide for the evangelical. (p. 74)

While all of these are valid attempts to understand why a younger or inexperienced pastor would be less likely to preach on financial issues than an older pastor, my experience tells me that experience matters. Money is an intimidating topic, especially for young or inexperienced pastors. They know, however, the subject matter must be addressed so they give the traditional one message a year. But with age comes confidence and also stronger conviction, in many cases, which leads to more messages in a year's time. Also with age comes a higher salary, which increases the church budget and the need to likely challenge the congregation in their giving.

\section{Finding Four}

The fourth finding of this study revealed a relationship with the size of churches. When considered together with Factor 1 (financial training/church finance) and Factor 2 (pastoral beliefs on giving and stewardship), pastors in congregations of larger churches $(250+)$ were more inclined to preach on financially related topics three or more times a year as compared to those in congregations of smaller size.

While only $12.1 \%$ of the pastors surveyed recorded they were in churches with weekly attendance over 250 people, larger churches do face unique issues in the financial area. A church of $250+$ is likely located in an area with growth potential and a more 
diverse population. The church likely has a larger budget, larger facility, more staff, and more potential opportunities for ministry. More staff, more space, and more ministry opportunities would likely present a backdrop to stress financial issues more often. A small church in a rural area with fewer than 100 people has little opportunity for growth and may not have those same opportunities.

One potential challenge larger churches face is free-riding. A free-rider is a church attendee or member who gives no or very little money yet still enjoys all of the benefits associated with being a part of a church body. Zaleski and Zech (1992) noted that congregational size and attitude toward the importance of church and religion are two critical considerations determining support for a church's mission and, thus, the extent of free ridership. To help understand the effect of free-riding, Ronsvalle and Ronsvalle (2000) noted the estimate elasticity was suggested that if a congregation grew by $10 \%$, contributions per member would fall by about $25 \%$. Evidence supported broad estimates that $30-50 \%$ of resident members gave little or nothing of record to their congregation. While these are intriguing figures, Ronsvalle and Ronsvalle (2000) note this was not necessarily the case for a church with an evangelical bent. Ronsvalle and Ronsvalle (2000) mentioned free-riding had been offered by some researchers as a major explanation in denominational differences in church giving. The theory stated that giving was higher in evangelical denominations because they have a stronger motive of reciprocity with God and more obligatory visible indicators of commitment.

Olson and Perl (2005) noted that compared to other congregations, strict, theologically conservative congregations have less skewed giving distributions and thus appeared to have fewer free- and cheap-riding participants, just as Iannaccone (1997) 
predicted. Though studying free-riders was not a part of my study, it is possible this could be less of an issue for larger Missionary Churches because (a) pastors in larger churches appear to be preaching at least three times annually; (b) the Missionary Church's value on faith commitment includes stewardship; and (c) the historical giving record of those in the Missionary Church is always at the top of reporting denominations (Table 15).

Second, overlooked among all the comments about how pastors disliked preaching on money or how they tiptoed around the subject matter is the simple fact that many pastors enjoy preaching financially centered sermons linked to Scripture and have found it enjoyable even if the subject matter was seemingly difficult (Wuthnow, 1998). One such difficult issue is materialism. Willmer (1995) noted, "The materialism of our culture is the dominant issue and the church had not combated materialism with its own set of values. People in the church often feel that if they take the biblical teaching on stewardship to heart, they would have to give up a lot that they don't want to do without" (as cited in Ronsvalle \& Ronsvalle, 1996). Yet, the Bible mentions you cannot serve two masters. "You can’t serve both God and money" (Matt 6:24). It is possible that pastors of larger Missionary Churches feel compelled to address this issue of materialism. In my survey, $83 \%$ of pastors believed materialism/consumerism affects those in their congregation; 78\% believed credit card debt is an issue in their church; 95\% of pastors believed consumerism affected people's ability to give more generously; and 99\% of pastors in my survey believed credit card debt is an issue in our society. Debt, for instance, would be an issue the Bible addresses and offers guidance and warning. Messages on financial issues and offering other financial training options (Crown 
Ministries, Financial Peace University, etc.) within the church serve as ways to keep congregational members on track with their personal faith commitment.

Wuthnow (1999) presented a third issue when he said people in his congregation simply don't think carefully enough about their money. They have not maintained budgets or records of their expenses. The Bible mentions being a steward of that which God has entrusted to His people. Alcorn (2001) wrote that because there is a fundamental connection between our spiritual lives and how we think about and handle money, we have tried to divorce faith from personal finances, but God sees them as inseparable. Recent work by Starks and Smith (2013) would support these thoughts as they note,

Most important of all, however, seems to be fostering parish cultures in which the use of money is not seen as a mere secular or profane matter but, as the Bible teaches, a spiritual concern that God cares about, that shapes one's personal spiritual life profoundly, and that can genuinely help transform the world along Christian values and purposes. That is the kind of belief, vision and culture that fosters generous Christian financial giving. (p. 27)

If the evangelical is engaged in the Bible, then indeed, the spiritual life and one's finances would be inseparable.

Fourth, the very name, Missionary Church, suggests an emphasis on outreach efforts. The denomination is active in a variety of mission works through individual church efforts and other outreach efforts in the U.S. and abroad. One way this emphasis is kept at the forefront of congregational minds is to preach on missions, which requires sacrificial giving. It also puts an emphasis on work done outside of the church. Sociologist Reginald Bibby noted, "Observers have drawn attention to the reality of routinization, whereby groups tended to turn inward, focused upon themselves as organizations, rather than on the original purpose that brought them into being (as cited in 
Ronsvalle \& Ronsvalle, 1996, p. 100). R.D. Roth (1987) mentioned that it is no small wonder that the people claim: All the church was interested in is money, or the church is always asking for money. It is a perception that is real and is backed by the limited outreach that occurs within today's church. This does not appear be the case in the Missionary Church, as 55\% of pastors in my survey responded that any annual increases in their budgets also address outreach efforts. In a Presbyterian Church study, Lunn et al. (2001) noted conservative theological beliefs were associated with greater total giving and greater giving for normal congregational uses; and for non-Presbyterian religious organizations, liberal theological beliefs were associated with greater giving for denominational purposes and for nonreligious charities. These conservative findings meshed with Missionary Church practice.

Lastly, the Alban Institute in conjunction with the Lake Institute on Faith \& Giving (2009) reported that almost $40 \%$ of the pastors $(N=1,496)$ in their study preached or talked about charitable giving either slightly more or significantly more than they did in the previous year. There was evidence that delivering financially based messages seemed to impact people’s lives. Wuthnow (1999) mentioned that among church members nationally, 65\% say the Bible contained valuable teachings about money. Allen (2005) shared that most interviewees who commented on stewardship sermons said that such preaching has played a positive role in helping them become better stewards. Several pointed out that sermons have been important in persuading them to tithe. Allen (2005) further recorded the testimony of interviewees who expressed the opinion that preachers should talk about stewardship more than they do: "I'd like to see us do a little bit more about stewardship and I'd like to see that addressed a little bit more directly. I 
want to know my purpose, my being and how I live out that purpose and that being. How do I become a better steward of God?” (pp. 2-3) Mulligan (2007) confirmed that the preacher's anxiety was not completely without foundation, but most laity are interested in Christian ideas about money. It would suggest that preaching routinely about financial topics as a part of our lives provides a more accepting climate. The research notes people are interested and it is probably a much more appealing approach then apologizing up and down before delivering the "annual once a year giving sermon."

\section{Conclusions}

While most previous research suggested pastors and congregations did not favor preaching on financially related issues, this study found widespread support and practice for preaching on financial issues by pastors in the Missionary Church. Factors that most predict preaching on financial issues are

1. Supportive personal beliefs on giving and stewardship

2. Education and training and a willingness to attend future training on financial issues

3. Personal commitment to giving/tithing

4. Openness of the congregation to address such topics from the pulpit in church

5. More years of ministry experience

6. Larger size of congregation.

This research also supports prior findings that link commitment to faith traditions and more preaching on financial matters as leading to more generous giving. 


\section{Recommendations}

The following are recommendations to (a) pastors and leaders of the Missionary Church for future considerations and (b) other researchers.

Pastors

1. Continue to challenge church attendees with messages on financial matters. Research suggests they are interested and want to know more so their life can be impacted and they can make a difference. Preaching on financial matters also aligns with the Missionary Church’s faith traditions, encouraging a stronger faith commitment and stewardship.

2. With younger or less experienced pastors less likely to preach on financially related topics two or more times annually, consider a mentoring program for newer pastors where they can share sermon thoughts, seek guidance, and receive encouragement from seasoned pastors.

3. Involve church members who have experience in specific financial areas as a part of an overall church plan to teach financial principles a pastor may feel inadequate addressing (such as investing, estate planning, debt, etc.)

\section{Leaders}

1. With a high percentage of pastors willing to attend future biblical financial training, consideration should be given to breakout session(s) on such topics at the biennial General Conference. 
2. Since Bethel College is the Missionary Church's denominational college and a producer of future pastors, work with Bethel to ensure all ministry students take a course or receive training on biblical financial principles and church finance.

3. Encourage all churches to engage in offering the Crown Ministries study, Financial Peace University, or other financial studies available for teaching financial principles in an effort to encourage all churches to have a carefully planned stewardship experience for their attendees.

\section{Recommendations for Further Research}

This study has been able to gather information about pastors in the Missionary Church and the efforts they give toward preaching on financially related topics. There do appear to be differences between results of my study and other previous research. The following recommendations for future research can add to this work.

1. Most other studies focus on the donor and donor trends. Because of the findings related to the number of times Missionary Church pastors preach on financially related topics, a study should be done on Missionary Church congregations to (a) gather congregational perspectives, and (b) see how giving statistics of Missionary Church attendees compare to other evangelical contribution figures and other mainline denominations.

2. In a further study, consider distinguishing between how often a pastor preaches on tithing/giving versus other financial topics such as debt, cosigning, investing, inheritance, etc.

3. Perform this same study in other conservative, evangelical denominations to see how those findings would compare to the results of this study. 
4. Consider further study, in general, on pastors and the role they may play in increased giving in a congregation and elsewhere.

5. Perform this same study in other mainline denominations to consider comparative results.

6. At the start of the study, I knew that the survey would have to be translated into Spanish to serve the large Hispanic/Latino community within the Missionary Church denomination. Whereas previous studies on socioeconomic behavior often look for differences by ethnicity, I had not found ethnicity to be a central variable in the research and scholarship on Christian stewardship and giving. However, given the large percentage of Spanish-speaking churches and pastors, I felt I should test for variability of ethnicity in this study. In the data analysis, I did not find any pattern that was significant or worth reporting, but continue to see more need for research in this area as economic variability in the general Hispanic/Latino population in the U.S., and also within the Missionary Church, is a contextual variable needing more exploration.

\section{Summary}

This study of pastors in the evangelical denomination of the Missionary Church has provided new information regarding pastors and their perspective of preaching on financially related topics. The data revealed $92 \%$ of pastors in the denomination preach on a financially related topic at least once a year, $66 \%$ of pastors who have been in ministry over 10 years preach two or more times annually on such topics, and pastors in churches of $250+$ in their congregation are likely to preach three or more times annually on financially related issues. 
This study also revealed considerable differences between Missionary Church pastors and those from prior research. Factors that most predict preaching on financial issues within the Missionary Church include (a) supportive personal beliefs on giving and stewardship; (b) education and training and a willingness to attend future training on financial issues; (c) personal commitment to giving/tithing; (d) openness of the congregation to address such topics from the pulpit in church; (e) more years of ministry experience; and (f) larger size of congregation. This research also supports prior findings that link commitment to faith traditions and more preaching on financial matters as leading to more generous giving. This commitment to preach regularly about financial topics may also contribute to research, which indicates evangelicals are more consistent tithers and more generous donors. 


\section{APPENDIX A}

\section{ENGLISH SURVEY QUESTIONNAIRE \\ Missionary Church, Inc. Preaching/Teaching Pastor Questionnaire}

Thank you for taking a few minutes to answer the questions on this survey. Your responses will help provide feedback for a doctoral dissertation that is seeking to measure comfort levels of pastors on preaching and teaching on financially related topics including giving. Be assured that your responses are strictly confidential. To insure anonymity once the survey is completed, it is requested that you place your survey in the envelope provided for you, seal it and return it to the designated individual identified during the verbal instructions. Do not put your name on this survey.

Directions: Answer each of the following questions by placing an $(\mathrm{X})$ in the box to the left of the choice that best represents your opinion. Mark only one choice per item. Thank you for your honest responses and participation.

\section{QUESTION 1}

In which Missionary Church District do you serve?

\begin{tabular}{|c|c|c|c|}
\hline$\square$ Central & $\square$ Central Texas & $\square$ El Paso Mission & $\square$ East Central \\
\hline$\square$ Florida & $\square$ Georgia/Alabama & $\square$ Hawaii & $\square$ Houston \\
\hline$\square$ Kentucky/Tenn. & $\square$ Michigan & $\square$ Mid-Atlantic & $\square$ Midwest \\
\hline$\square$ New England & $\square$ North Central & $\square$ North/South Car. & $\square$ Northwest \\
\hline$\square$ Puerto Rico & $\square$ Rio Grande Valley & $\square$ Western & $\square$ Eastern \\
\hline
\end{tabular}

\section{QUESTION 2}

Your age?

$\begin{array}{lll}\square \text { less than 25 } & \square 4044 & \square 6064 \\ \square 25-29 & \square 45-49 & \square 65-69 \\ \square 3034 & \square 5054 & \square 7074 \\ \square 35-39 & \square 55-59 & \square 75 \text { or more }\end{array}$




\section{QUESTION 3}

Your race/ethnicity?

$\square$ White/Caucasian $\square$ Asian/Pacific Islander $\square$ Hispanic/Latino

$\square$ Black/African American $\square$ Other

\section{QUESTION 4}

Your marital status?
Married
$\square$ Widower
$\square$ Divorced

$\square$ Never Married $\quad \square$ Separated

\section{QUESTION 5}

How many children do you have living at home?
$\square 0$
$\square 1$
$\square 2$
$\square 3$
$\square 4$
$\square 5$ or more

\section{QUESTION 6}

Your total years in ministry?

$\begin{array}{lll}\square \text { lessthan } 5 & \square 2024 & \square 4044 \\ \square \text {-5 } & \square 25-29 & \square 45-49 \\ \square 1014 & \square 3034 & \square 5054 \\ \square 15-19 & \square 35-39 & \square 55 \text { or more }\end{array}$

\section{QUESTION 7}

Your years as a preaching/teaching pastor?

$\begin{array}{lll}\square \text { lessthan } 5 & \square 2024 & \square 40-44 \\ \square 5-9 & \square 25-29 & \square 45-49 \\ \square 1014 & \square 3034 & \square 5054 \\ \square 15-19 & \square 35-39 & \square 55 \text { or more }\end{array}$




\section{QUESTION 8}

Current Ministry Status

$\square$ Fulltime

Partime

Bivocational

\section{QUESTION 9}

Number of years as the preaching/teaching pastor at your current church?

$\square$ less than $1 \quad \square 1014$

$\square 1-2 \quad \square 15-19$

$\square 3-5 \square 2024$

$\square 99 \quad \square 25$ or more

\section{QUESTION 10}

What is your total annual compensation package (Salary, housing, medical, education, etc...)?
$\square$ less than $\$ 10,000$
$\$ 50,000-59,000$
$\$ 90,000-99,000$
$\$ 10,000-19,000$
$\$ 60,000-69,000$
$\$ 100,000-109,000$
$\$ 20,000-29,000$
$\$ 70,000-79,000$
$\$ 110,000-119,000$
$\$ 30,000-39,000$
$\$ 80,000-89,000$
$\$ 120,000$ or mare

$\$ 40,000-49,000$

\section{QUESTION 11}

What is the current average weekend attendance at the church you serve?

$\begin{array}{ll}\square \text { less than } 100 & \square 500749 \\ \square 100149 & \square 750999 \\ \square 150-249 & \square 1,000-1,499 \\ \square 250499 & \square 1,500 \text { or more }\end{array}$




\section{QUESTION 12}

Your highest earned level of education

\section{$\square$ High School}

$\square 2$ year Associates Degree

4 year Bachelors Degree

Masters Degree

$\square$ Ph.D.

\section{QUESTION 13}

One of my educational degrees has a Christian emphasis or was earned from a Christian College or seminary?

$\square$ Yes

$\square$ No

\section{QUESTION 14}

Do you, your spouse or someone else handle the finances (writing bills, balancing checkbook, etc...) in your home?

$\square$ I handle these tasks

My spouse handles these tasks

Both my spouse and I share this responsibility

Someone else handles these tasks

\section{QUESTION 15}

Which best describes your personal giving level on an annual basis?

$\square$ Less than $10 \%$ of my household after tax income

An amount equal to $10 \%$ of my household after tax income

More than $10 \%$ of my household after tax income 


\section{QUESTION 16}

Which best describes your overall personal debt situation (Refers to all debt including mortgage, credit card, education loan(s), vehicle loan(s), etc...)?

I have no debt

$\square$ I have minimal debt and it does not provide stress in my life

I have moderate debtand it provides stress from time to time

I have considerable debt and it is always in the back of my head

$\square$ I have substantial debt, enough to provide significant personal stress in my life

\section{QUESTION 17}

In a typical calendar year, how many weekend messages do you completely dedicate to preaching or teaching on a financial topic?

$\begin{array}{ll}\square 0 & \square 3 \\ \square 1 & \square 4 \\ \square 2 & \square 5 \text { or more }\end{array}$

\section{QUESTION 18}

Which of the following best describes your churches financial position?

$\square$ The church rarely, if ever, meets our budget

The church meets our annual budget but typically do not go above and beyond the set budget.

$\square$ The church generally exceeds our annual budget

\section{QUESTION 19}

I am very comfortable preaching/teaching on financially related topics

$\square$ Strongly Agree $\square$ Agree $\square$ Disagree $\square$ Strongly Disagree

\section{QUESTION 20}

I believe tithing is still applicable for today's Christian

$\square$ Strongly Agree $\square$ Agree $\square$ Disagree $\square$ Strongly Disagree 


\section{QUESTION 21}

I believe the tithe is meant to come directly to the church

Strongly Agree $\square$ Agree $\square$ Disagree $\square$ Strongly Disagree

\section{QUESTION 22}

I received biblical financial training as a part of my educational experience

Strongly Agree $\square$ Agree $\square$ Disagree $\square$ Strongly Disagree

\section{QUESTION 23}

I received biblical financial training since entering the ministry

$\square$ Strongly Agree $\square$ Agree $\square$ Disagree $\square$ Strongly Disagree

\section{QUESTION 24}

I am willing to attend biblical financial training in the future
$\square$ Strongly Agree
$\square$ Agree
Disagree
$\square$ Strongly Disagree

\section{QUESTION 25}

I am comfortable with my current compensation package

$\square$ Strongly Agree $\square$ Agree $\square$ Disagree $\square$ Strongly Disagree

\section{QUESTION 26}

Being liked by my congregation is important to me

$\square$ Strongly Agree $\square$ Agree $\square$ Disagree $\square$ Strongly Disagree

\section{QUESTION 27}

My church is supportive of me

$\square$ Strongly Agree $\square$ Agree $\square$ Disagree $\square$ Strongly Disagree




\section{QUESTION 28}

I believe the pastor should know the giving records of those who attend their church

$\square$ Strongly Agree $\square$ Agree $\square$ Disagree $\square$ Strongly Disagree

\section{QUESTION 29}

I am aware of the individual giving records of those in my congregation
Yes
$\square$ No
I know some but not all

\section{QUESTION 30}

I feel pressure in my church to not talk about money/finances

$\square$ Strongly Agree $\square$ Agree $\square$ Disagree $\square$ Strongly Disagree

\section{QUESTION 31}

Annual increases in our church budget mostly address outreach efforts

Strongly Agree $\square$ Agree $\square$ Disagree $\square$ Strongly Disagree

\section{QUESTION 32}

Annual increases in our church budget mostly address operational expenses
Strongly Agree
$\square$ Agree
Disagree
Strongly Disagree

\section{QUESTION 33}

I believe materialism/consumerism affects those in my congregation

$\square$ Strongly Agree $\square$ Agree $\square$ Disagree $\square$ Strongly Disagree

\section{QUESTION 34}

Credit card debt is an issue in my church

$\square$ Strongly Agree $\square$ Agree $\square$ Disagree $\square$ Strongly Disagree

\section{QUESTION 35}

Those in my congregation who are the most generous are the most happy
Strongly Agree
Agree
Disagree
Strongly Disagree 


\section{QUESTION 36}

I support the Missionary Church’s statement of stewardship (see page 9 for full statement)

$\square$ Strongly Agree $\quad \square$ Agree $\quad \square$ Disagree $\quad \square$ Strongly Disagree

\section{QUESTION 37}

My church offers Financial Peace University (Dave Ramsey) as an option of study for our congregation

Yes

$\square$ No

\section{QUESTION 38}

My church offers Crown Financial Ministry as an option of study for our congregation

$\square$ Yes

$\square$ No

\section{QUESTION 39}

My church offers another form of financial training to our congregation

$\square$ Yes (if yes, please identify here

$\square$ No

\section{QUESTION 40}

Society believes "all pastors do is talk for money"

$\square$ Strongly Agree $\square$ Agree $\quad \square$ Disagree $\square$ StronglyDisagree

\section{QUESTION 41}

I believe consumer debt affects people's ability to give more generously

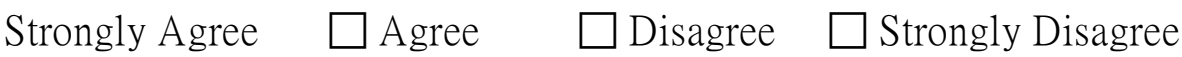




\section{QUESTION 42}

Society believes "all pastors do is ask for money"
Strongly Agree
Agree
$\square$ Disagree
Strongly Disagree

\section{QUESTION 43}

Credit card debt is an issue in our country
Strongly Agree
$\square$ Agree
$\square$ Disagree
Strongly Disagree

\section{Thank you for your participation in this survey.}

Please place your survey in the envelope provided for you, seal it and turn it in to the designated individual identified during the verbal instructions. Do not put your name on this sheet.

Missionary Church Statement on Stewardship:

a) God's owner of all things creatively and redemptively is unquestioned in the scriptures. Since we are saved by grace and the death of Christ provided our ransom, our whole being, body, soul, and spirit should be freely given to God, which is our reasonable service. b) Not only does God claim our love and devotion, but He has made us stewards of what we have in time, talent, and temporal goods. Since giving of our means to support the Lord's work is a scriptural injunction and an act of worship received and memorialized by our Lord, and since tithing antedates the Mosaic Law, was confirmed in the Law, and was approved by our Lord Jesus Christ, and since the New Testament clearly indicates that our giving is to be proportionate, believers are encouraged to adopt the system of tithing their income as a minimum expression of their stewardship. Our stewardship in material things is to be motivated by the spirit and example of our Lord who freely gave Himself for us all. Gen. 14:20, Mal. 3:8, 10; Matt. 23:23; Acts 4:32; 1 Cor 16:2; 2 Cor. 8:9, 9:6-7 (www.mcusa.org). 


\section{APPENDIX B}

\section{SPANISH SURVEY QUESTIONNAIRE}

\section{Iglesia Misionera Cuestionario de Pastoreo y Enseñanza}

Gracias por responder a las preguntas de esta encuesta. Sus respuestas serán usadas como parte de una investigación para una tesis doctoral que propone medir niveles de confortabilidad de pastores en el acto de predicar y enseñar sobre temas financieras. Todas sus respuestas serán confidenciales. Para asegurar que su encuesta sea completada en una forma anónima, por favor póngalo en el sobre que lo acompaña, ciérralo, y retórnalo a la persona indicada. Por favor no escriba su nombre en esta encuesta.

Direcciones: Indique sus respuestas poniendo (X) en la caja a la izquierda de la opción que mejor describe su opinión. Indique solo una respuesta por pregunta. Gracias por su honestidad y participación.

\section{PREGUNTA 1}

¿En qué distrito de la Iglesia Misionera sirve?

\begin{tabular}{|c|c|c|c|}
\hline$\square$ Central & $\square$ Texas Central & $\square$ Misión de El Paso & $\square$ Este Centra \\
\hline Florida & $\square$ Georgia/Alabama & $\square$ Hawai & $\square$ Houston \\
\hline Kentucky/Tenn. & $\square$ Michigan & $\square$ MedioAtlántico & $\square$ Midwest \\
\hline New England & $\square$ Norte Central & $\square$ Carolina. & $\square$ Noreste \\
\hline Puerto Rico & $\square$ Valle Río Grande & $\square$ Oeste & $\square$ Este \\
\hline
\end{tabular}

\section{PREGUNTA 2}

¿Qué edad tiene?

$\begin{array}{lll}\square \text { menor que 25 } & \square 40-44 & \square 6064 \\ \square 25-29 & \square 45-49 & \square 65-69 \\ \square 3034 & \square 5054 & \square 7074 \\ \square 35-39 & \square 55-59 & \square \text { mayor de 75 }\end{array}$




\section{PREGUNTA 3}

¿Cuál es su raza/etnicidad?

$\square$ Americano/Blanco $\square$ Asiático $\square$ Hispánico/Latino

Africano Americano $\square$ Otro

\section{PREGUNTA 4}

¿Cuál es su estado civil?

$\begin{array}{ll}\square \text { Casado } & \square \text { Viudo } \quad \square \text { Divorciado } \\ \square \text { Nunca casado } & \square \text { Separado sin divorcio }\end{array}$

\section{PREGUNTA 5}

¿Cuántos hijos tiene viviendo en casa?
$\square 0$
$\square 1$
$\square 2$
$\square 3$
$\square 4$
$\square 50$ más

\section{PREGUNTA 6}

¿Cuántos años a trabajado en el ministerio?

$\begin{array}{lll}\square \text { menos de } 5 & \square 2024 & \square 40-44 \\ \square 5-9 & \square 25-29 & \square 45-49 \\ \square 1014 & \square 3034 & \square 5054 \\ \square 15-19 & \square 35-39 & \square 55 \text { o mas }\end{array}$

\section{PREGUNTA 7}

¿Cuántos años a trabajado como pastor?

$\begin{array}{lll}\square \text { menos de } 5 & \square 2024 & \square 40-44 \\ \square 5-9 & \square 25-29 & \square 45-49 \\ \square 1014 & \square 3034 & \square 5054 \\ \square 15-19 & \square 35-39 & \square 55 \text { o mas }\end{array}$




\section{PREGUNTA 8}

Estado ministerial

$\square$ Tiempo completo

$\square$ Tiempo parcial

Bivocacional

\section{PREGUNTA 9}

¿Cuántos años a trabajado como pastor de su presente iglesia?

$\begin{array}{ll}\square \text { menos de } 1 & \square 1014 \\ \square 1-2 & \square 15-19 \\ \square 3-5 & \square 2024 \\ \square 69 & \square 25 \text { o mas }\end{array}$

\section{PREGUNTA 10}

¿Qué valor tiene su combinada compensación anual (Salario, vivienda, medicinal, educación, etc....)?

$\begin{array}{lll}\square \text { menos de } \$ 10,000 & \square \$ 50,000-59,000 & \square \$ 90,000-99,000 \\ \square \$ 10,000-19,000 & \square \$ 60,000-69,000 & \square \$ 100,000-109,000 \\ \square \$ 20,000-29,000 & \square \$ 70,000-79,000 & \square \$ 110,000-119,000 \\ \square \$ 30,000-39,000 & \square \$ 80,000-89,000 & \square \$ 120,000 \text { o mas }\end{array}$

$\$ 40,000-49,000$

\section{PREGUNTA 11}

¿Qué promedio de asistencia tiene su presente iglesia?
$\square$ menos de 100
500749
100149
750999
$\square$ 150- 249
$1,000-1,499$
250499
1,500 o más 


\section{PREGUNTA 12}

¿Cuál es su nivel mas alto de educación?

$\square$ Escuela Secundaria

$\square$ Tł́ulo de Asociados (2 años)

$\square$ Título de Licenciatura (4 años)

$\square$ Título de Maestría

Doctorado

PREGUNTA 13

¿Adquirió algún titulo educativo en una universidad cristiana o en un seminario?

$\square \mathrm{Si}$

$\square$ No

\section{PREGUNTA 14}

En su hogar, ¿quién se encarga de la contabilidad financiera?

\section{Usted}

Su esposo o esposa

Usted y su esposo o esposa juntos

$\square$ Otra persona

\section{PREGUNTA 15}

¿Cómo describiría la cantidad que ofrenda cada año?

Menos de $10 \%$ del ingreso anual de mi hogar

Aproximadamente $10 \%$ del ingreso anual de mi hogar

$\square$ Más de 10\% del ingreso anual de mi hogar 


\section{PREGUNTA 16}

¿Cómo describiría la situación de sus deudas financieras (por ejemplo: hipotética, tarjetas de crédito, o deudas de educación o vehiculo)?

$\square$ No tengo deuda

Tengo poca deuda que no me causa estrés

$\square$ Tengo una cantidad de deuda moderada que me causa estrés de vez en cuando

$\square$ Tengo una cantidad de deuda considerable que me causa estrés casi constantemente

Tengo tanta deuda que casi no pienso en otras cosas

\section{PREGUNTA 17}

En un año típico, ¿cuántos mensajes dedica a temas financieras?

$\begin{array}{ll}\square 0 & \square 3 \\ \square 1 & \square 4 \\ \square 2 & \square 5 \text { о ḿ }\end{array}$

\section{PREGUNTA 18}

¿Cómo describiría la posición financiero de su iglesia?

La iglesia casi nunca se sale del presupuesto

La iglesia generalmente llega al nivel del presupuesto, pero no lo sobrepasa

La iglesia casi siempre se sale del presupuesto

\section{PREGUNTA 19}

¿Se siente cómodo predicando y enseñando sobre temas financieras?

Si, estoy muy cómodo $\square$ Estoy cómodo

$\square$ No estoy cómodo $\quad \square$ Me opongo firmemente a predicar sobre estas temas

\section{PREGUNTA 20}

¿Está de acuerdo que la práctica del diezmo sigue siendo aplicable a la iglesia de hoy?

$\square \mathrm{Si}$, estoyfirmemente de acuerdo $\square$ Estoy de acuerdo

$\square$ No estoy de acuerdo $\quad \square$ Me opongo firmemente 


\section{PREGUNTA 21}

Diezmos deben pasar directamente a la iglesia.

Si, estoyfirmemente de acuerdo $\square$ Estoy de acuerdo

$\square$ No estoy de acuerdo

$\square$ Me opongo firmemente

\section{PREGUNTA 22}

Recibí instrucción financiera bíblica como parte de mi experiencia educacional.

$\square$ Si, estoyfirmemente de acuerdo $\square$ Estoy de acuerdo

$\square$ No estoy de acuerdo $\quad \square$ Me opongo firmemente

\section{PREGUNTA 23}

He recibido instrucción financiera bíblica después de entrar al ministerio.

$\square$ Si, estoyfirmemente de acuerdo $\square$ Estoy de acuerdo

$\square$ No estoy de acuerdo $\quad \square$ Me opongo firmemente

\section{PREGUNTA 24}

No me opondría a recibir instrucción financiera bíblica en el futuro.

$\square$ Si, estoyfirmemente de acuerdo $\square$ Estoy de acuerdo

No estoy de acuerdo $\square$ Me opongo firmemente

\section{PREGUNTA 25}

Estoy cómodo con mi compensación anual.

$\square$ Si, estoyfirmemente de acuerdo $\square$ Estoy de acuerdo

$\square$ No estoy de acuerdo $\quad \square$ Me opongo firmemente

\section{PREGUNTA 26}

Es importante para mi llevarme bien con mi congregación.

$\mathrm{Si}$, estoy firmemente de acuerdo $\square$ Estoy de acuerdo

$\square$ No estoy de acuerdo $\quad \square$ Me opongo firmemente 


\section{PREGUNTA 27}

Mi iglesia me apoya.

$\square$ Si, estoy firmemente de acuerdo $\square$ Estoy de acuerdo

$\square$ No estoy de acuerdo $\square$ Meopongo firmemente

\section{PREGUNTA 28}

Yo creo que el pastor debe tener registros de los diezmos y ofrendas de los que atienden a su iglesia.

$\square$ Si, estoy firmemente de acuerdo $\square$ Estoy de acuerdo

No estoy de acuerdo

$\square$ Me opongo firmemente

\section{PREGUNTA 29}

Yo tengo una buena idea de las cantidades de los diezmos y ofrendas de los que atienden a mi iglesia.

$\square$ Si $\quad \square$ No $\quad \square$ Se las cantidades de algunas pero no todas

\section{PREGUNTA 30}

Siento que mi iglesia me presiona a no hablar sobre dinero u otras temas financieras.

$\square$ Si, esta es mi experiencia $\square$ Estoy de acuerdo

$\square$ No estoy de acuerdo $\quad \square$ No, de ninguna manera

\section{PREGUNTA 31}

Aumentos anuales en el presupuesto de mi iglesia generalmente se usan para trabajos sociales o misiones.

Si, estoy firmemente de acuerdo $\square$ Estoy deacuerdo

$\square$ No estoy de acuerdo $\quad \square$ Me opongo firmemente

\section{PREGUNTA 32}

Aumentos anuales en el presupuesto de mi iglesia generalmente se usan para operaciones locales de la iglesia.

$\square$ Si, estoy firmemente de acuerdo $\square$ Estoy de acuerdo

$\square$ No estoy de acuerdo $\quad \square$ Me opongo firmemente 


\section{PREGUNTA 33}

Yo creo que el materialismo afecta a mi congregación.

$\square$ Si, estoy firmemente de acuerdo $\square$ Estoy de acuerdo

No estoy de acuerdo $\square$ Me opongo firmemente

\section{PREGUNTA 34}

Deuda de tarjeta de crédito es un problema serio para miembros de mi congregación.

$\square$ Si, estoy firmemente de acuerdo $\square$ Estoy de acuerdo

$\square$ No estoy de acuerdo $\square$ Me opongo firmemente

\section{PREGUNTA 35}

Los miembros más generosos de mi congregación son los mas felices.

$\square$ Si, estoy firmemente de acuerdo $\square$ Estoy de acuerdo

$\square$ No estoy de acuerdo $\square$ Me opongo firmemente

\section{PREGUNTA 36}

Yo estoy de acuerdo con la Declaración de Mayordomía de la Iglesia Misionera (la declaración está reproducida en el final de esta encuesta).

$\square$ Si, estoy firmemente de acuerdo $\square$ Estoy de acuerdo

No estoy de acuerdo $\square$ Me opongo firmemente

\section{PREGUNTA 37}

En mi iglesia se puede obtener Financial Peace University (Dave Ramsey) como una opción de estudio para la congregación.

\section{$\square \mathrm{Si}$}

$\square$ No

\section{PREGUNTA 38}

En mi iglesia se puede obtener Crown Financial Ministry como una opción de estudio financiero para la congregación.

$\square \mathrm{Si}$

$\square$ No 


\section{PREGUNTA 39}

En mi iglesia se puede obtener otra forma de estudio financiero para la congregación.

$\square \mathrm{Si}$

$\square$ No

\section{PREGUNTA 40}

La sociedad cree que todo lo que hacen los pastores es hablar de dinero.

$\square$ Si, estoy firmemente de acuerdo $\square$ Estoy de acuerdo

$\square$ No estoy de acuerdo $\square$ Me opongo firmemente

\section{PREGUNTA 41}

Yo creo que deuda afecta nuestra habilidad para ofrendar.

$\mathrm{Si}$, estoy firmemente deacuerdo $\square$ Estoy de acuerdo

$\square$ No estoy de acuerdo $\quad \square$ Me opongo firmemente

\section{PREGUNTA 42}

La sociedad cree que todo lo que hacen los pastores es pedir dinero.

$\square$ Si, estoy firmemente de acuerdo $\square$ Estoy de acuerdo

$\square$ No estoy de acuerdo $\quad \square$ Me opongo firmemente

\section{PREGUNTA 43}

Deuda de tarjeta de crédito es un problema serio en nuestro país.

$\mathrm{Si}$, estoy firmemente de acuerdo $\square$ Estoy de acuerdo

$\square$ No estoy de acuerdo

$\square$ Me opongo firmemente 


\section{Gracias por su participación.}

\section{Por favor ponga su encuesta en el sobre, ciérralo, y retórnalo a la persona indicada. No escriba su nombre sobre este documento.}

Declaración de Mayordomía de la Iglesia Misionera:

a) Las escrituras dicen que Dios es dueño absoluta de todo lo que existe. Como somos salvados por la gracia de Dios y por el sacrificio de la muerte de su hijo Jesucristo, todo lo que somos debe ser dado gratuitamente a El.

b) Dios no quiere solamente nuestro amor y devoción, pero también nuestro tiempo, talento, y bienes temporales. Como dando de lo que tenemos para apoyar el trabajo de nuestro Señor es un requerimiento bíblico y acto de adoración recibida de y reconocida por nuestro Señor, y como nuestros diezmos anteceden la ley de Moisés y fue aprobado por nuestro Señor Jesucristo, y como el Nuevo Testamento indica claramente que ofrendas deben ser mínimamente proporcionales a diezmos, se les anima a los creyentes que adopten un sistema de diezmo como expresión de su mayordomía. Nuestra mayordomía en cosas materiales debe ser motivada por el espíritu y ejemplo de nuestro Señor, quien dio gratuitamente de el mismo para nosotros. Gen. 14:20, Mal. 3:8, 10; Mat. 23:23; Hechos 4:32; 1 Cor 16:2; 2 Cor. 8:9, 9:6-7 (www.mcusa.org). 
APPENDIX C

OPERATIONAL VARIABLES

\begin{tabular}{|c|c|c|c|}
\hline $\begin{array}{c}\text { Variable and } \\
\text { Survey Question }\end{array}$ & Conceptual Definition & $\begin{array}{l}\text { Instrumental } \\
\text { Definition }\end{array}$ & $\begin{array}{l}\text { Operational } \\
\text { Definition }\end{array}$ \\
\hline $\begin{array}{l}\text { District (Dem) } \\
\text { (Survey Question } \\
\# 1 \text { ) }\end{array}$ & $\begin{array}{l}\text { Refers to one of the } 20 \\
\text { districts The } \\
\text { Missionary Church is } \\
\text { divided into. }\end{array}$ & $\begin{array}{l}\text { Check MC District } \\
\text { served in on survey }\end{array}$ & $\begin{array}{l}\text { Central = } 1 \\
\text { Central TX = } 2 \\
\text { El Paso = } 3 \\
\text { East Central = } 4 \\
\text { Florida = 5 } \\
\text { Geo/Ala = } 6 \\
\text { Hawaii = } 7 \\
\text { Houston = } 8 \\
\text { Ken/Tenn = 9 } \\
\text { Michigan = 10 } \\
\text { Mid-Atlan = 11 } \\
\text { Midwest = 12 } \\
\text { New Eng = 13 } \\
\text { N. Central = 14 } \\
\text { N/S Carol = 15 } \\
\text { Norhwest = 16 } \\
\text { Puerto Rico }-17 \\
\text { Rio Grande = 18 } \\
\text { Western = 19 } \\
\text { Eastern = 20 }\end{array}$ \\
\hline $\begin{array}{l}\text { Age (Dem) } \\
\text { (Survey Question } \\
\text { \# 2) }\end{array}$ & $\begin{array}{l}\text { Refers to the pastor's } \\
\text { age as identified in one } \\
\text { of twelve age groups } \\
\text { provided. }\end{array}$ & $\begin{array}{l}\text { Defined by age } \\
\text { range }\end{array}$ & $\begin{array}{l}\text { Less than } 25=1 \\
25-29=2 \\
30-34=3 \\
35-39=4 \\
40-44=5 \\
45-49=6 \\
50-54=7 \\
55-59=8 \\
60=64=9 \\
65-69=10 \\
70-74=11 \\
75+=12\end{array}$ \\
\hline $\begin{array}{l}\text { Race/Ethnicity } \\
\text { (Dem) } \\
\text { (Survey Question } \\
\text { \# 3) }\end{array}$ & $\begin{array}{l}\text { Refers to the pastor's } \\
\text { race/ethnicity. }\end{array}$ & $\begin{array}{l}\text { A.White/Cauca } \\
\text { B. Black/African. } \\
\text { American } \\
\text { C. Hispanic/Latino } \\
\text { D. Asian/Pacific } \\
\quad \text { Islander } \\
\text { E. Bi-racial, Bi- } \\
\text { Cultural }\end{array}$ & $\begin{array}{l}\text { White/Cauca }=1 \\
\text { Black/African. } \\
\text { American = } 2 \\
\text { Hispanic/Latino } \\
=3 \text { Asian/Pacific } \\
\text { Islander }=4 \\
\text { Other }=5\end{array}$ \\
\hline
\end{tabular}




\begin{tabular}{|c|c|c|c|}
\hline $\begin{array}{l}\text { Marital Status } \\
\text { (Dem) } \\
\text { (Survey Question } \\
\text { \# 4) }\end{array}$ & $\begin{array}{l}\text { Refers to the pastors } \\
\text { marital status }\end{array}$ & $\begin{array}{l}\text { A. Married } \\
\text { B. Widower } \\
\text { C. Divorced } \\
\text { D. Never } \\
\text { married } \\
\text { E. Separated }\end{array}$ & $\begin{array}{l}\text { Married = } 1 \\
\text { Widower }=2 \\
\text { Divorced }=3 \\
\text { Never married = } \\
4 \\
\text { Separated }=5\end{array}$ \\
\hline $\begin{array}{l}\text { Children (Dem) } \\
\text { (Survey Question } \\
\text { \# 5) }\end{array}$ & $\begin{array}{l}\text { Refers to the number of } \\
\text { children living under } \\
\text { the pastors roof }\end{array}$ & $\begin{array}{l}\text { A. } 0 \\
\text { B. } 1 \\
\text { C. } 2 \\
\text { D. } 3 \\
\text { E. } 4 \\
\text { F. } 5 \text { or more } \\
\end{array}$ & $\begin{array}{l}0=0 \\
1=1 \\
2=2 \\
3=3 \\
4=4 \\
5 \text { or more }=5\end{array}$ \\
\hline $\begin{array}{l}\text { Total Years } \\
\text { (TotYrs) } \\
\text { (Dem) } \\
\text { (Survey Question } \\
\text { \# 6) }\end{array}$ & $\begin{array}{l}\text { Refers to the pastor's } \\
\text { total number of years } \\
\text { he has been involved in } \\
\text { ministry. }\end{array}$ & $\begin{array}{l}\text { Defined by } 5 \text { year } \\
\text { ranges }\end{array}$ & $\begin{array}{l}\text { Less than } 5=1 \\
5-9=2 \\
10-14=3 \\
15-19=4 \\
20-24=5 \\
25-29=6 \\
30-34=7 \\
35-39=8 \\
40-44=9 \\
45-49=10 \\
50-54=11 \\
\text { More than } 55= \\
12\end{array}$ \\
\hline $\begin{array}{l}\text { Years as } \\
\text { Preaching/Teachi } \\
\text { ng Pastor } \\
\text { (YrsPTP) (Dem) } \\
\text { (Survey Question } \\
\text { \# 7) }\end{array}$ & $\begin{array}{l}\text { Refers to the number of } \\
\text { years a pastor has } \\
\text { served as a } \\
\text { preaching/teaching } \\
\text { pastor. }\end{array}$ & $\begin{array}{l}\text { Defined by } 5 \text { year } \\
\text { ranges }\end{array}$ & $\begin{array}{l}\text { Less than } 5=1 \\
5-9=2 \\
10-14=3 \\
15-19=4 \\
20-24=5 \\
25-29=6 \\
30-34=7 \\
35-39=8 \\
40-44=9 \\
45-49=10 \\
50-54=11 \\
<55=12\end{array}$ \\
\hline $\begin{array}{l}\text { Current Status } \\
\text { (CurrStat) (Dem) } \\
\text { (Survey Question } \\
\text { \# 8) }\end{array}$ & $\begin{array}{l}\text { Refers to whether a } \\
\text { pastor is currently full- } \\
\text { time or part-time, or } \\
\text { Bi-vocational }\end{array}$ & $\begin{array}{l}\mathrm{A}=\text { full time } \\
\mathrm{B}=\text { part time } \\
\mathrm{C}=\mathrm{Bi} \text {-vocational }\end{array}$ & $\begin{array}{l}\text { full time }=1 \\
\text { part time }=2 \\
\text { Bi-vocational }= \\
3\end{array}$ \\
\hline $\begin{array}{l}\text { Years } \\
\text { Preaching/Teachi } \\
\text { ng Pastor at }\end{array}$ & $\begin{array}{l}\text { Refers to the number of } \\
\text { years a pastor has } \\
\text { served as the }\end{array}$ & $\begin{array}{l}\text { Defined by year } \\
\text { ranges }\end{array}$ & $\begin{array}{l}\text { Less than } 1=1 \\
1-2=2 \\
3-5=3\end{array}$ \\
\hline
\end{tabular}




\begin{tabular}{|c|c|c|c|}
\hline $\begin{array}{l}\text { Current Church } \\
\text { (PTPChu) (Dem) } \\
\text { (Survey Question } \\
\text { \# 9) }\end{array}$ & $\begin{array}{l}\text { preaching/teaching } \\
\text { pastor at his current } \\
\text { church. }\end{array}$ & & $\begin{array}{l}6-9=4 \\
10-14=5 \\
15-19=6 \\
20-24=7 \\
25 \text { or more }=8\end{array}$ \\
\hline $\begin{array}{l}\text { Compensation } \\
\text { (Dem) } \\
\text { (Survey Question } \\
\text { \# 10) }\end{array}$ & $\begin{array}{l}\text { Refers to a pastors total } \\
\text { compensation package. }\end{array}$ & $\begin{array}{l}\text { Defined in } \$ 10 \mathrm{~K} \\
\text { ranges }\end{array}$ & $\begin{array}{l}\text { Less than } 10 \mathrm{~K}= \\
1 \\
10 \mathrm{~K}-19 \mathrm{~K}=2 \\
20 \mathrm{~K}-29 \mathrm{~K}=3 \\
30 \mathrm{~K}-39 \mathrm{~K}=4 \\
40 \mathrm{~K}-49 \mathrm{~K}=5 \\
50 \mathrm{~K}-59 \mathrm{~K}=6 \\
60 \mathrm{~K}-69 \mathrm{~K}=7 \\
70 \mathrm{~K}-79 \mathrm{~K}=8 \\
80 \mathrm{~K}-89 \mathrm{~K}=9 \\
90 \mathrm{~K}-99 \mathrm{~K}=10 \\
100-110 \mathrm{~K}=11 \\
120 \mathrm{~K}+=12\end{array}$ \\
\hline $\begin{array}{l}\text { Church } \\
\text { Attendance } \\
\text { (ChAttend) (Dem) } \\
\text { (Survey Question } \\
\text { \# 11) }\end{array}$ & $\begin{array}{l}\text { Refers to the average } \\
\text { weekend attendance at } \\
\text { the pastors church. }\end{array}$ & Defined by ranges & $\begin{array}{l}\text { Less than } 100= \\
1 \\
100-149=2 \\
150-249=3 \\
250-499=4 \\
500-749=5 \\
750-999=6 \\
1000-1499=7 \\
1500+=8\end{array}$ \\
\hline $\begin{array}{l}\text { Education } \\
\text { (Educate) (Dem) } \\
\text { (Survey Question } \\
\text { \# 12) }\end{array}$ & $\begin{array}{l}\text { Refers to the pastors } \\
\text { highest earned level of } \\
\text { education. }\end{array}$ & $\begin{array}{l}\text { a. High School } \\
\text { b. } 2 \text { year assoc } \\
\text { c. } 4 \text { year bachlors } \\
\text { d. Masters } \\
\text { e. Ph.D }\end{array}$ & $\begin{array}{l}\text { High School }=1 \\
2 \text { year assoc }=2 \\
4 \text { year bach }=3 \\
\text { Masters }=4 \\
\text { Ph.D }=5\end{array}$ \\
\hline $\begin{array}{l}\text { Christian } \\
\text { Education } \\
\text { (ChristEd) (Dem) } \\
\text { (Survey Question } \\
\text { \# 13) }\end{array}$ & $\begin{array}{l}\text { Refers to whether one } \\
\text { of the pastors degrees } \\
\text { has a Christian } \\
\text { emphasis or was earned } \\
\text { at a Christian College. }\end{array}$ & $\begin{array}{l}\text { Degree or College } \\
\text { had a Christian } \\
\text { emphasis } \\
\text { A.Yes } \\
\text { B. No }\end{array}$ & $\begin{array}{l}\text { Yes }=0 \\
\text { No }=1\end{array}$ \\
\hline $\begin{array}{l}\text { Home finances } \\
\text { (Dem) } \\
\text { (Survey Question } \\
\text { \# 14) }\end{array}$ & $\begin{array}{l}\text { Refers to who handles } \\
\text { the home finances }\end{array}$ & $\begin{array}{ll}\text { a. } & \text { Pastor does } \\
\text { b. } & \text { Spouse does } \\
\text { c. } & \text { Both do } \\
\text { d. } & \text { Someone } \\
& \text { else does } \\
\end{array}$ & $\begin{array}{l}\text { Pastor }=1 \\
\text { Spouse }=2 \\
\text { Both }=3 \\
\text { Someone else }= \\
4 \\
\end{array}$ \\
\hline $\begin{array}{l}\text { Giving (Personal) } \\
\text { (Survey Question }\end{array}$ & $\begin{array}{l}\text { Refers to the pastors } \\
\text { personal giving level. }\end{array}$ & $\begin{array}{l}\text { Defined by } \\
\text { Percentage } \\
<10 \%\end{array}$ & $\begin{array}{l}<10 \%=1 \\
=10 \%=2 \\
>10 \%=3\end{array}$ \\
\hline
\end{tabular}




\begin{tabular}{|c|c|c|c|}
\hline \# 15) & & $\begin{array}{l}=10 \% \\
>10 \%\end{array}$ & \\
\hline $\begin{array}{l}\text { Debt (Personal) } \\
\text { (Survey Question } \\
\# 16 \text { ) }\end{array}$ & $\begin{array}{l}\text { Refers to the pastors } \\
\text { personal debt situation. }\end{array}$ & $\begin{array}{l}\text { a. None } \\
\text { b. minimal and no } \\
\text { stress } \\
\text { c. moderate and } \\
\text { occasional stress } \\
\text { d. considerable debt } \\
\text { and always feel } \\
\text { stress } \\
\text { e. substantial debt } \\
\text { and significant } \\
\text { stress }\end{array}$ & $\begin{array}{l}\text { None }=1 \\
\text { minimal and no } \\
\text { stress }=2 \\
\text { moderate and } \\
\text { occasional stress } \\
=3 \\
\text { considerable } \\
\text { debt and always } \\
\text { feel stress = } 4 \\
\text { substantial debt } \\
\text { and significant } \\
\text { stress = 5 }\end{array}$ \\
\hline $\begin{array}{l}\text { Churches } \\
\text { financial position } \\
\text { (Church) } \\
\text { (Survey Question } \\
\text { \# 18) }\end{array}$ & $\begin{array}{l}\text { Refers to the churches } \\
\text { ability to meet its } \\
\text { annual budget }\end{array}$ & $\begin{array}{l}\text { Personal view of } \\
\text { annual performance }\end{array}$ & $\begin{array}{l}\text { Church rarely } \\
\text { meets budget = } 1 \\
\text { Church typically } \\
\text { meets right at } \\
\text { budget = } 2 \\
\text { Church generally } \\
\text { exceeds budget = } \\
3\end{array}$ \\
\hline $\begin{array}{l}\text { Comfort } \\
\text { (Personal) } \\
\text { (Survey Question } \\
\text { \# 19) }\end{array}$ & $\begin{array}{l}\text { refers to the pastors } \\
\text { comfort level when } \\
\text { preaching/teaching on a } \\
\text { financially related } \\
\text { topic. }\end{array}$ & $\begin{array}{l}\text { Personal attitude on } \\
\text { comfort }\end{array}$ & $\begin{array}{l}\text { Strongly Agree = } \\
1 \\
\text { Agree }=2 \\
\text { Disagree }=3 \\
\text { Strongly } \\
\text { Disagree }=4\end{array}$ \\
\hline $\begin{array}{l}\text { Tithing (Personal) } \\
\text { (Survey Question } \\
\text { \# 20) }\end{array}$ & $\begin{array}{l}\text { Refers to the pastors } \\
\text { attitude related to } \\
\text { tithing for today’s } \\
\text { Christian. }\end{array}$ & $\begin{array}{l}\text { Personal attitude of } \\
\text { tithing }\end{array}$ & $\begin{array}{l}\text { Strongly Agree = } \\
1 \\
\text { Agree }=2 \\
\text { Disagree = } 3 \\
\text { Strongly } \\
\text { Disagree }=4\end{array}$ \\
\hline $\begin{array}{l}\text { Tithe comes to the } \\
\text { church (Personal) } \\
\text { (Survey Question } \\
\text { \# 21) }\end{array}$ & $\begin{array}{l}\text { Refers to the pastors } \\
\text { personal belief that the } \\
\text { whole tithe should } \\
\text { come to the church }\end{array}$ & $\begin{array}{l}\text { Personal attitude on } \\
\text { whether the whole } \\
\text { tithe should come } \\
\text { to the church }\end{array}$ & $\begin{array}{l}\text { Strongly Agree = } \\
1 \\
\text { Agree }=2 \\
\text { Disagree }=3 \\
\text { Strongly } \\
\text { Disagree }=4\end{array}$ \\
\hline $\begin{array}{l}\text { Biblical Financial } \\
\text { Education (FinEd) } \\
\text { (Personal) } \\
\text { (Survey Question } \\
\text { \# 22) }\end{array}$ & $\begin{array}{l}\text { Refers to a pastor } \\
\text { receiving biblical } \\
\text { financial training as a } \\
\text { part of his education. }\end{array}$ & $\begin{array}{l}\text { Pastor either } \\
\text { received some level } \\
\text { of training or he did } \\
\text { not }\end{array}$ & $\begin{array}{l}\text { Strongly Agree = } \\
1 \\
\text { Agree }=2 \\
\text { Disagree }=3 \\
\text { Strongly } \\
\text { Disagree }=4\end{array}$ \\
\hline
\end{tabular}




\begin{tabular}{|c|c|c|c|}
\hline $\begin{array}{l}\text { Biblical Financial } \\
\text { Training Since } \\
\text { Entering Ministry } \\
\text { (FinTrM) } \\
\text { (Personal) } \\
\text { (Survey Question } \\
\text { \# 23) }\end{array}$ & $\begin{array}{l}\text { Refers to a pastor } \\
\text { having received } \\
\text { biblical financial } \\
\text { training since entering } \\
\text { the ministry. }\end{array}$ & $\begin{array}{l}\text { Pastor has received } \\
\text { financial training } \\
\text { since entering the } \\
\text { ministry }\end{array}$ & $\begin{array}{l}\text { Strongly Agree = } \\
1 \\
\text { Agree }=2 \\
\text { Disagree }=3 \\
\text { Strongly } \\
\text { Disagree }=4\end{array}$ \\
\hline $\begin{array}{l}\text { Willing to attend } \\
\text { Biblical Financial } \\
\text { Training in the } \\
\text { Future (FinTrF) } \\
\text { (Personal) } \\
\text { (Survey Question } \\
\text { \# 24) }\end{array}$ & $\begin{array}{l}\text { Refers to the pastors } \\
\text { willingness to attend } \\
\text { biblical financial } \\
\text { training in the future. }\end{array}$ & $\begin{array}{l}\text { Pastor would be } \\
\text { willing to attend } \\
\text { future training }\end{array}$ & $\begin{array}{l}\text { Strongly Agree = } \\
1 \\
\text { Agree }=2 \\
\text { Disagree = } 3 \\
\text { Strongly } \\
\text { Disagree }=4\end{array}$ \\
\hline $\begin{array}{l}\text { Comfort with } \\
\text { Compensation } \\
\text { Package } \\
\text { (Compack) } \\
\text { (Personal) } \\
\text { (Survey Question } \\
\text { \# 25) }\end{array}$ & $\begin{array}{l}\text { Refers to a pastors } \\
\text { comfort level with their } \\
\text { current salary. }\end{array}$ & $\begin{array}{l}\text { Pastors attitude } \\
\text { toward what he is } \\
\text { paid }\end{array}$ & $\begin{array}{l}\text { Strongly Agree = } \\
1 \\
\text { Agree }=2 \\
\text { Disagree = } 3 \\
\text { Strongly } \\
\text { Disagree }=4\end{array}$ \\
\hline $\begin{array}{l}\text { Liked (Personal) } \\
\text { (Survey Question } \\
\text { \# 26) }\end{array}$ & $\begin{array}{l}\text { Refers to a pastors } \\
\text { desire to be liked by his } \\
\text { congregation }\end{array}$ & $\begin{array}{l}\text { Pastors on if it is } \\
\text { important to be } \\
\text { liked? }\end{array}$ & $\begin{array}{l}\text { Strongly Agree = } \\
1 \\
\text { Agree }=2 \\
\text { Disagree }=3 \\
\text { Strongly } \\
\text { Disagree }=4\end{array}$ \\
\hline $\begin{array}{l}\text { Support } \\
\text { (Personal) } \\
\text { (Survey Question } \\
\text { \# 27) }\end{array}$ & $\begin{array}{l}\text { Refers to a pastor } \\
\text { feeling the support of } \\
\text { his congregation. }\end{array}$ & $\begin{array}{l}\text { Attitude that Pastor } \\
\text { feels the overall } \\
\text { support of his } \\
\text { congregation }\end{array}$ & $\begin{array}{l}\text { Strongly Agree = } \\
1 \\
\text { Agree }=2 \\
\text { Disagree }=3 \\
\text { Strongly } \\
\text { Disagree }=4\end{array}$ \\
\hline $\begin{array}{l}\text { Pastor Should } \\
\text { Know } \\
\text { Congregations } \\
\text { Giving } \\
\text { (ShldKnow) } \\
\text { (Personal) } \\
\text { (Survey Question } \\
\text { \# 28) }\end{array}$ & $\begin{array}{l}\text { Refers to whether a } \\
\text { pastor believes the } \\
\text { pastor should know the } \\
\text { giving levels of people } \\
\text { in his congregation. }\end{array}$ & $\begin{array}{l}\text { Attitude of a pastor } \\
\text { on whether he feels } \\
\text { the pastor should } \\
\text { know the giving of } \\
\text { people in his } \\
\text { congregation }\end{array}$ & $\begin{array}{l}\text { Strongly Agree = } \\
1 \\
\text { Agree }=2 \\
\text { Disagree = } 3 \\
\text { Strongly } \\
\text { Disagree }=4\end{array}$ \\
\hline Knows (Personal) & refers to whether a & Does the pastor & Yes $=1$ \\
\hline
\end{tabular}




\begin{tabular}{|c|c|c|c|}
\hline $\begin{array}{l}\text { (Survey Question } \\
\text { \# 29) }\end{array}$ & $\begin{array}{l}\text { pastor knows the giving } \\
\text { levels of those who } \\
\text { attend his church. }\end{array}$ & $\begin{array}{l}\text { know giving } \\
\text { records of those in } \\
\text { his congregation }\end{array}$ & $\begin{array}{l}\text { No }=2 \\
\text { Know some but } \\
\text { not all = } 3\end{array}$ \\
\hline $\begin{array}{l}\text { Pressure (Inst) } \\
\text { (Survey Question } \\
\text { \# 30) }\end{array}$ & $\begin{array}{l}\text { Refers to pressure a } \\
\text { pastor feels in his } \\
\text { church to not talk about } \\
\text { money/finances. }\end{array}$ & $\begin{array}{l}\text { Does pastor feel } \\
\text { pressure that he } \\
\text { should not discuss } \\
\text { money in church }\end{array}$ & $\begin{array}{l}\text { Strongly Agree = } \\
1 \\
\text { Agree }=2 \\
\text { Disagree }=3 \\
\text { Strongly } \\
\text { Disagree }=4\end{array}$ \\
\hline $\begin{array}{l}\text { Outreach (Inst) } \\
\text { (Survey Question } \\
\text { \# 31) }\end{array}$ & $\begin{array}{l}\text { Refers to annual } \\
\text { increase in church } \\
\text { budget mostly goes to } \\
\text { support outreach. }\end{array}$ & $\begin{array}{l}\text { Pastors knowledge } \\
\text { of whether } \\
\text { increases in the } \\
\text { budget are outreach } \\
\text { oriented }\end{array}$ & $\begin{array}{l}\text { Strongly Agree = } \\
1 \\
\text { Agree }=2 \\
\text { Disagree = } 3 \\
\text { Strongly } \\
\text { Disagree }=4\end{array}$ \\
\hline $\begin{array}{l}\text { Operational } \\
\text { (Operate) (Inst) } \\
\text { (Survey Question } \\
\text { \# 32) }\end{array}$ & $\begin{array}{l}\text { Refers to annual } \\
\text { increases in church } \\
\text { budget mostly going to } \\
\text { support operational } \\
\text { increases in the budget. }\end{array}$ & $\begin{array}{l}\text { Pastors knowledge } \\
\text { of whether } \\
\text { increases in the } \\
\text { budget are } \\
\text { operations oriented }\end{array}$ & $\begin{array}{l}\text { Strongly Agree = } \\
1 \\
\text { Agree }=2 \\
\text { Disagree = } 3 \\
\text { Strongly } \\
\text { Disagree }=4\end{array}$ \\
\hline $\begin{array}{l}\text { Materialism/Cons } \\
\text { umerism Affects } \\
\text { His } \\
\text { Congregational } \\
\text { (M/CCong) (Inst) } \\
\text { (Survey Question } \\
\text { \# 33) }\end{array}$ & $\begin{array}{l}\text { Refers to whether or } \\
\text { not a pastor believes } \\
\text { materialism/consumeris } \\
\text { m affects those in his } \\
\text { congregation }\end{array}$ & $\begin{array}{l}\text { Pastors attitude } \\
\text { toward } \\
\text { materialism/consu } \\
\text { merism of thos in } \\
\text { his congregation }\end{array}$ & $\begin{array}{l}\text { Strongly Agree = } \\
1 \\
\text { Agree }=2 \\
\text { Disagree }=3 \\
\text { Strongly } \\
\text { Disagree }=4\end{array}$ \\
\hline $\begin{array}{l}\text { Credit Card Debt } \\
\text { an Issue in } \\
\text { Pastor's Church } \\
\text { (CCCou) (Inst) } \\
\text { (Survey Question } \\
\text { \# 34) }\end{array}$ & $\begin{array}{l}\text { Refers to a pastors } \\
\text { attitude on credit card } \\
\text { debt being an issue in } \\
\text { the country. }\end{array}$ & $\begin{array}{l}\text { Pastors attitude on } \\
\text { credit card debt in } \\
\text { our country }\end{array}$ & $\begin{array}{l}\text { Strongly Agree = } \\
1 \\
\text { Agree }=2 \\
\text { Disagree = } 3 \\
\text { Strongly } \\
\text { Disagree }=4\end{array}$ \\
\hline $\begin{array}{l}\text { Happy (Inst) } \\
\text { (Survey Question } \\
\text { \# 35) }\end{array}$ & $\begin{array}{l}\text { Refers to a pastors } \\
\text { opinion on whether } \\
\text { those he knows to be } \\
\text { the most generous in } \\
\text { his congregation are } \\
\text { also the most happy. }\end{array}$ & $\begin{array}{l}\text { Pastors attitude and } \\
\text { outlook toward } \\
\text { people who give } \\
\text { generously verses } \\
\text { those who do not }\end{array}$ & $\begin{array}{l}\text { Strongly Agree = } \\
1 \\
\text { Agree }=2 \\
\text { Disagree = } 3 \\
\text { Strongly } \\
\text { Disagree }=4\end{array}$ \\
\hline $\begin{array}{l}\text { Missionary } \\
\text { Church }\end{array}$ & $\begin{array}{l}\text { Refers to a pastors } \\
\text { support of the }\end{array}$ & $\begin{array}{l}\text { Pastor supports the } \\
\text { MC stance }\end{array}$ & $\begin{array}{l}\text { Strongly Agree = } \\
1\end{array}$ \\
\hline
\end{tabular}




\begin{tabular}{|c|c|c|c|}
\hline $\begin{array}{l}\text { Stewardship } \\
\text { Statement } \\
\text { (MCStew) (Inst) } \\
\text { (Survey Question } \\
\text { \# 36) }\end{array}$ & $\begin{array}{l}\text { Missionary Churches } \\
\text { statement on } \\
\text { stewardship. }\end{array}$ & & $\begin{array}{l}\text { Agree }=2 \\
\text { Disagree }=3 \\
\text { Strongly } \\
\text { Disagree }=4\end{array}$ \\
\hline $\begin{array}{l}\text { Financial Peace } \\
\text { University (FPU) } \\
\text { (Inst) } \\
\text { (Survey Question } \\
\text { \# 37) }\end{array}$ & $\begin{array}{l}\text { Refers to a pastor’s } \\
\text { church offering } \\
\text { Financial Peace } \\
\text { University. }\end{array}$ & Church offers FPU & $\begin{array}{l}\text { Yes }=0 \\
\text { No }=1\end{array}$ \\
\hline $\begin{array}{l}\text { Crown Financial } \\
\text { Ministry (CrMin) } \\
\text { (inst) } \\
\text { (Survey Question } \\
\text { \# 38) }\end{array}$ & $\begin{array}{l}\text { Refers to a pastors } \\
\text { church offering Crown } \\
\text { Financial Ministry } \\
\text { Study. }\end{array}$ & $\begin{array}{l}\text { Church offers } \\
\text { Crown Financial } \\
\text { Ministry }\end{array}$ & $\begin{array}{l}\text { Yes }=0 \\
\text { No }=1\end{array}$ \\
\hline $\begin{array}{l}\text { Other Financial } \\
\text { Study (OtherFS) } \\
\text { (inst) } \\
\text { (Survey Question } \\
\text { \# 39) }\end{array}$ & $\begin{array}{l}\text { Refers to a pastors } \\
\text { church offering a } \\
\text { financial study other } \\
\text { that Financial Peace } \\
\text { University or Crown } \\
\text { Ministry Financial } \\
\text { Study to his } \\
\text { congregation. }\end{array}$ & $\begin{array}{l}\text { Church offers some } \\
\text { other form of } \\
\text { financial education } \\
\text { for congregation }\end{array}$ & $\begin{array}{l}\text { Yes }=0 \\
\text { No }=1\end{array}$ \\
\hline $\begin{array}{l}\text { Society Believes } \\
\text { Pastor Just Talks } \\
\text { About Money } \\
\text { (SocTalk) (Social) } \\
\text { (Survey Question } \\
\text { \# 40) }\end{array}$ & $\begin{array}{l}\text { Refers to a pastors } \\
\text { opinion on society } \\
\text { believes all a pastor } \\
\text { does is talk about } \\
\text { money. }\end{array}$ & $\begin{array}{l}\text { Does pastor feel or } \\
\text { hear all pastors do } \\
\text { is talk about money }\end{array}$ & $\begin{array}{l}\text { Strongly Agree = } \\
1 \\
\text { Agree }=2 \\
\text { Disagree = } 3 \\
\text { Strongly } \\
\text { Disagree }=4\end{array}$ \\
\hline $\begin{array}{l}\text { Materialism/Cons } \\
\text { umerism affects } \\
\text { giving (M/CGive) } \\
\text { (Social) } \\
\text { (Survey Question } \\
\text { \# 41) }\end{array}$ & $\begin{array}{l}\text { Refers to whether a } \\
\text { pastor believes } \\
\text { mater./consumerism } \\
\text { affects people's ability } \\
\text { to give more } \\
\text { generously }\end{array}$ & $\begin{array}{l}\text { Does pastor believe } \\
\text { giving is affected }\end{array}$ & $\begin{array}{l}\text { Strongly Agree = } \\
1 \\
\text { Agree }=2 \\
\text { Disagree }=3 \\
\text { Strongly } \\
\text { Disagree }=4\end{array}$ \\
\hline $\begin{array}{l}\text { Society and } \\
\text { Pastor Asking } \\
\text { (SocAsk) (Social) } \\
\text { (Survey Question }\end{array}$ & $\begin{array}{l}\text { Refers to a pastors } \\
\text { opinion on Society } \\
\text { believes all a pastor } \\
\text { does is ask for money }\end{array}$ & $\begin{array}{l}\text { Does pastor feel or } \\
\text { hear all pastors do } \\
\text { is ask for money }\end{array}$ & $\begin{array}{l}\text { Strongly Agree = } \\
1 \\
\text { Agree }=2 \\
\text { Disagree }=3 \\
\text { Strongly }\end{array}$ \\
\hline
\end{tabular}




\begin{tabular}{|l|l|l|l|}
\hline $\begin{array}{l}\text { \# 42) } \\
\begin{array}{l}\text { Credit Card Debt } \\
\text { country (CCC) } \\
\text { (Social) }\end{array}\end{array}$ & $\begin{array}{l}\text { Refers to pastors } \\
\text { opinion if Credit Card } \\
\text { debt is an issue in our } \\
\text { country }\end{array}$ & $\begin{array}{l}\text { Does Pastor feel } \\
\text { this is an issue }\end{array}$ & $\begin{array}{l}\text { Strongly Agree } \\
1 \\
\text { Agree }=2 \\
\text { Disagree }=3 \\
\text { Survey Question }\end{array}$ \\
$\begin{array}{l}\text { \# 43) } \\
\text { Number of times } \\
\text { per year } \\
\text { preach/teach on a } \\
\text { financial topic } \\
\text { (Preachit) (Dep. } \\
\text { Var) }\end{array}$ & $\begin{array}{l}\text { Refers to the number } \\
\text { of times in a calendar } \\
\text { year a pastor dedicates } \\
\text { the entire } \\
\text { message/sermon to } \\
\text { preaching or teaching } \\
\text { on a financially related } \\
\text { topic. }\end{array}$ & $\begin{array}{l}\text { Number identifying } \\
\text { how many times a } \\
\text { pastor } \\
\text { preaches/teaches } \\
\text { annually on a } \\
\text { financially related } \\
\text { topic }\end{array}$ & $\begin{array}{l}0=0 \\
1 \text { time=1 } \\
2 \text { times=2 } \\
3 \text { times=3 } \\
4 \text { times=4 } \\
5 \text { or more times } \\
=5\end{array}$ \\
\hline
\end{tabular}




\section{APPENDIX D}

VARIABLES WORKSHEET WITH CITED REFERENCES

\begin{tabular}{|c|c|c|c|c|}
\hline Variable Type & Ind. Variables & $\begin{array}{l}\text { Survey } \\
\text { Number }\end{array}$ & Source & Source Application, Concept \\
\hline Demographic & District & 1 & & \\
\hline Demographic & Age & 2 & & \\
\hline Demographic & Race/Ethnicity & 3 & & \\
\hline Demographic & Marital Status & 4 & & \\
\hline Demographic & Number of Children & 5 & & \\
\hline Demographic & Years in Ministry & 6 & & \\
\hline Demographic & $\begin{array}{l}\text { Years as Preaching / } \\
\text { Teaching Pastor }\end{array}$ & 7 & & \\
\hline Demographic & $\begin{array}{l}\text { Full-time / Part-time / } \\
\text { Bi-Vocational }\end{array}$ & 8 & & \\
\hline Demographic & $\begin{array}{l}\text { Years at current } \\
\text { church }\end{array}$ & 9 & & \\
\hline Demographic & $\begin{array}{l}\text { Current compensation } \\
\text { package }\end{array}$ & 10 & & \\
\hline Demographic & $\begin{array}{l}\text { Current church ave. } \\
\text { weekend attendance }\end{array}$ & 11 & & \\
\hline Demographic & Level of education & 12 & & \\
\hline Demographic & $\begin{array}{l}\text { Degree from Christian } \\
\text { Instit. Or Seminary }\end{array}$ & 13 & & \\
\hline Demographic & $\begin{array}{l}\text { Who handles home } \\
\text { finances }\end{array}$ & 14 & & \\
\hline \multirow[t]{3}{*}{ Personal } & \multirow[t]{3}{*}{$\begin{array}{l}\text { Personal Giving } \\
\text { Practice }\end{array}$} & \multirow[t]{3}{*}{15} & Mulder (1999) & $\begin{array}{l}\text { Giving money is giving away } \\
\text { one's self }\end{array}$ \\
\hline & & & Allen (2005) & $\begin{array}{l}\text { issue of integrity is big with } \\
\text { parishioners }\end{array}$ \\
\hline & & & Wheeler & Pastor must lead by example \\
\hline \multirow[t]{2}{*}{ Personal } & \multirow[t]{2}{*}{$\begin{array}{l}\text { Personal Financial } \\
\text { Situation }\end{array}$} & \multirow[t]{2}{*}{16} & $\begin{array}{l}\text { Ronsvalle and } \\
\text { Ronsvalle (1996) }\end{array}$ & $\begin{array}{l}\text { lack of training affects personal } \\
\text { finances }\end{array}$ \\
\hline & & & $\begin{array}{l}\text { Hoge, McNamara, } \\
\text { and Zech (1997) }\end{array}$ & $\begin{array}{l}\text { can't handle my own, how can I } \\
\text { teach others }\end{array}$ \\
\hline \multirow[t]{2}{*}{ Institutional } & \multirow[t]{2}{*}{$\begin{array}{l}\text { Churches Financial } \\
\text { Condition }\end{array}$} & \multirow[t]{2}{*}{18} & $\begin{array}{l}\text { Ronsvalle and } \\
\text { Ronsvalle (1999) }\end{array}$ & $\begin{array}{l}\text { Depression and WWII giving vs } \\
\text { today }\end{array}$ \\
\hline & & & $\begin{array}{l}\text { Robinson in } \\
\text { Stowell (1987) }\end{array}$ & $\begin{array}{l}\text { Spirituality defined by } \\
\text { checkbook }\end{array}$ \\
\hline
\end{tabular}




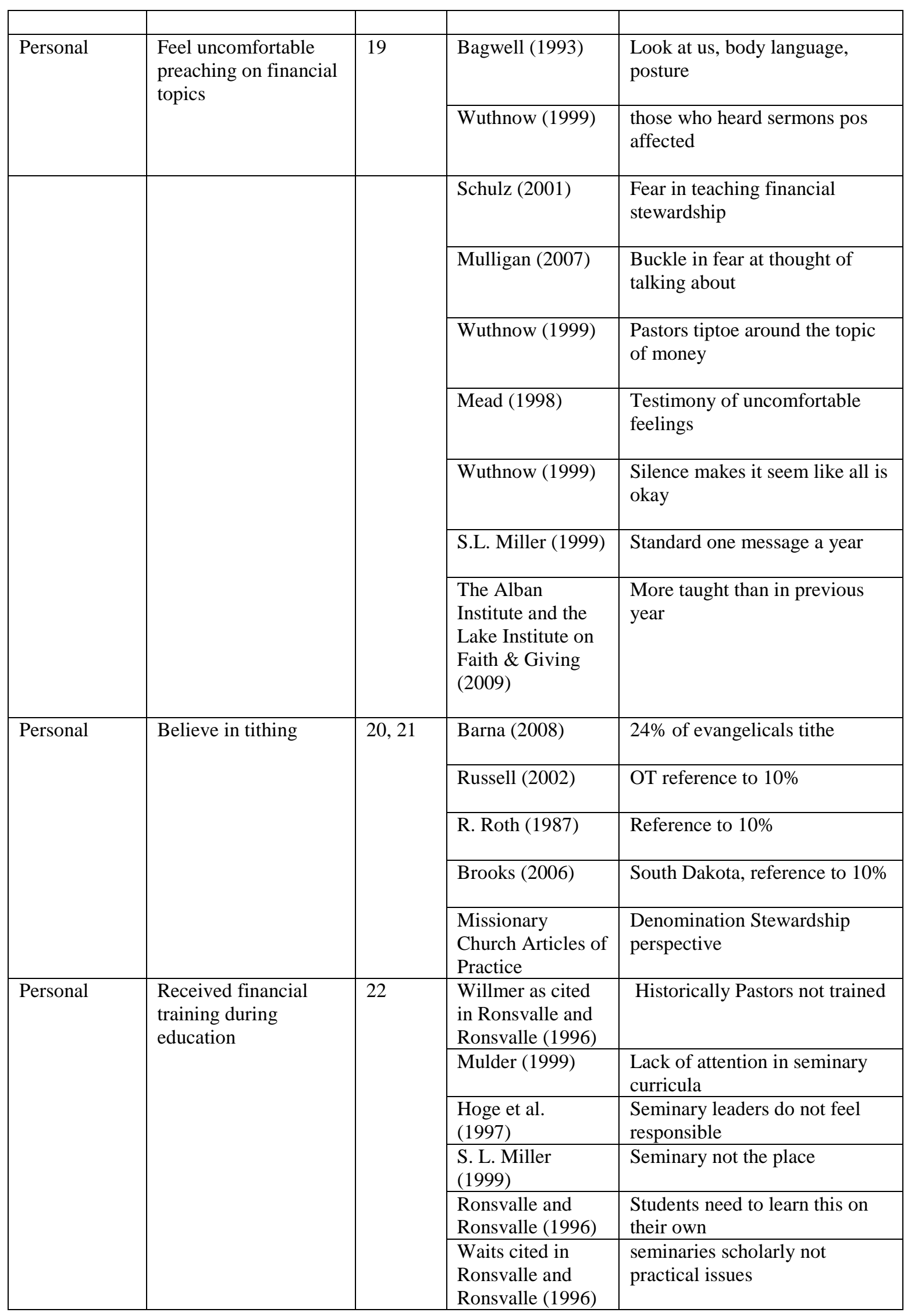




\begin{tabular}{|c|c|c|c|c|}
\hline & & & $\begin{array}{l}\text { Taylor cited in } \\
\text { Ronsvalle and } \\
\text { Ronsvalle (1996) }\end{array}$ & $\begin{array}{l}\text { But first problem pastors face is } \\
\text { financial }\end{array}$ \\
\hline & & & Hoge et al. (1997) & $\begin{array}{l}\text { Seminary faculty lack practical } \\
\text { church experience. }\end{array}$ \\
\hline & & & $\begin{array}{l}\text { S. L. Miller } \\
\text { (1999) }\end{array}$ & $\begin{array}{l}<15 \% \text { of pastors satisfied with } \\
\text { financial training }\end{array}$ \\
\hline & & & $\begin{array}{l}\text { S. L. Miller } \\
\text { (1999) }\end{array}$ & not required in seminary \\
\hline Personal & $\begin{array}{l}\text { Received financial } \\
\text { training since entering } \\
\text { the ministry }\end{array}$ & 23 & & \\
\hline Personal & $\begin{array}{l}\text { Willingness to attend } \\
\text { future financial } \\
\text { training }\end{array}$ & 24 & $\begin{array}{l}\text { S. L. Miller } \\
\text { (1999) }\end{array}$ & $\begin{array}{l}\text { 15\% Protestant/14\% Catholic } \\
\text { clergy willing }\end{array}$ \\
\hline & & & $\begin{array}{l}\text { Ronsvalle and } \\
\text { Ronsvalle (1996) }\end{array}$ & $\begin{array}{l}\text { want to concentrate of } \\
\text { theological/liturgical }\end{array}$ \\
\hline Personal & $\begin{array}{l}\text { Personal view of } \\
\text { compensation }\end{array}$ & 25 & $\begin{array}{l}\text { Ronsvalle and } \\
\text { Ronsvalle (1996) }\end{array}$ & $\begin{array}{l}\text { Pastors feel like preaching is } \\
\text { raising salary }\end{array}$ \\
\hline & & & Mead (1998) & $\begin{array}{l}\text { "I felt guilty about our own } \\
\text { family situation }\end{array}$ \\
\hline & & & Wuthnow (1997) & $\begin{array}{l}\text { Clergy middle class though } \\
\text { many are really not }\end{array}$ \\
\hline Personal & Desire to be likes & 26 & Hoge et al. (1997) & $\begin{array}{l}\text { Fear of criticism for preaching } \\
\text { the topic }\end{array}$ \\
\hline & & & Hoge et al. (1997) & Most pastors are loved \\
\hline & & & Stowell (1987) & $\begin{array}{l}\text { Don't apologize for preaching } \\
\text { on money }\end{array}$ \\
\hline Personal & $\begin{array}{l}\text { Pastor feels supported } \\
\text { by church }\end{array}$ & 27 & Hoge et al. (1997) & $\begin{array}{l}\text { Fear of criticism for preaching } \\
\text { this topic }\end{array}$ \\
\hline & & & Hoge et al. (1997) & Most pastors are loved \\
\hline Personal & $\begin{array}{l}\text { Pastor knows giving } \\
\text { amounts of }\end{array}$ & 28,29 & Brooks (2006) & 225 Mill give/75 Mill do not \\
\hline & congregation & & $\begin{array}{l}\text { Zaleski and Zech } \\
\text { (1992) }\end{array}$ & Protestant women give more \\
\hline & & & $\begin{array}{l}\text { Luidens and } \\
\text { Nemeth (1994) }\end{array}$ & $\begin{array}{l}\text { Education correlates to slightly } \\
\text { higher giving }\end{array}$ \\
\hline & & & $\begin{array}{l}\text { Luidens and } \\
\text { Nemeth (1994) }\end{array}$ & $\begin{array}{l}\text { Higher income, higher gifts; } \\
\text { lower income, greater \% of } \\
\text { income given }\end{array}$ \\
\hline & & & Zaleski and & Free riders \\
\hline
\end{tabular}




\begin{tabular}{|c|c|c|c|c|}
\hline & & & Zech(1992) & \\
\hline & & & $\begin{array}{l}\text { Olsen and Perl } \\
\text { (2005) }\end{array}$ & Cheap riders \\
\hline & & & Hoge (1995) & Easy riders \\
\hline & & & $\begin{array}{l}\text { Miller, Parfet, and } \\
\text { Zech (2001) }\end{array}$ & Speak of free riding \\
\hline & & & $\begin{array}{l}\text { Ronsvalle and } \\
\text { Ronsvalle (2000) }\end{array}$ & Speak of free riding \\
\hline & & & $\begin{array}{l}\text { Luidens and } \\
\text { Nemeth (1994) }\end{array}$ & Importance of involvement \\
\hline & & & Donahue (1994) & Importance of involvement \\
\hline & & & $\begin{array}{l}\text { Hoge } \\
(1994)(1995)\end{array}$ & Importance of involvement \\
\hline & & & Iannaccone (1997) & Importance of involvement \\
\hline & & & $\begin{array}{l}\text { Lunn, Klay, and } \\
\text { Douglass (2001) }\end{array}$ & Importance of involvement \\
\hline & & & Inskeep (1994) & $\begin{array}{l}\text { Giving systems increase levels } \\
\text { of giving }\end{array}$ \\
\hline & & & $\begin{array}{l}\text { Miller et al. } \\
\text { (2001) }\end{array}$ & Tithing effort increased giving \\
\hline & & & White (1989) & Fervency of faith and giving \\
\hline & & & $\begin{array}{l}\text { Ronsvalle and } \\
\text { Ronsvalle (1996) }\end{array}$ & Controversial issue \\
\hline & & & $\begin{array}{l}\text { Ronsvalle and } \\
\text { Ronsvalle (1996) }\end{array}$ & $\begin{array}{l}\text { Conference statistics of feelings } \\
\text { of this. rather talk about sex } \\
\text { than money }\end{array}$ \\
\hline Institutional & $\begin{array}{l}\text { Pastor believes church } \\
\text { feels he talks too much }\end{array}$ & 30 & Hoge et al. (1997) & $\begin{array}{l}\text { You're always talking about } \\
\text { money }\end{array}$ \\
\hline & about money & & $\begin{array}{l}\text { Ronsvalle and } \\
\text { Ronsvalle (1996) }\end{array}$ & $\begin{array}{l}\text { Example of "one sermon per } \\
\text { year" }\end{array}$ \\
\hline & & & $\begin{array}{l}\text { Ronsvalle and } \\
\text { Ronsvalle (1996) }\end{array}$ & Example of "time of the year" \\
\hline & & & $\begin{array}{l}\text { Ronsvalle and } \\
\text { Ronsvalle (1996) }\end{array}$ & $\begin{array}{l}\text { Example of "man walking out } \\
\text { the center isle }\end{array}$ \\
\hline & & & Mead (1998) & $\begin{array}{l}\text { Pastors excoriated for preaching } \\
\text { to much }\end{array}$ \\
\hline & & & $\begin{array}{l}\text { Ronsvalle and } \\
\text { Ronsvalle (1996) }\end{array}$ & $\begin{array}{l}\text { "We don't discuss money in } \\
\text { this church" }\end{array}$ \\
\hline Institutional & $\begin{array}{l}\text { Increases in church } \\
\text { budget focus on }\end{array}$ & 31 & $\begin{array}{l}\text { Ronsvalle and } \\
\text { Ronsvalle (1996) }\end{array}$ & $\begin{array}{l}\text { Churches failure to focus on } \\
\text { others }\end{array}$ \\
\hline & & & Noll (2007) & $\begin{array}{l}\text { Evangelical desire to reach the } \\
\text { lost }\end{array}$ \\
\hline & & & Mulder (1999) & Impact of Christology \\
\hline & & & Barna (2008) & $\begin{array}{l}\text { Evangelical are more generous } \\
\text { givers }\end{array}$ \\
\hline & & & Noll (2007) & $\begin{array}{l}\text { Evang. Greatest supporters of } \\
\text { Para-Church }\end{array}$ \\
\hline & & & Willmer (1995) & $\begin{array}{l}\text { Appox } 15-40 \% \text { of evangelical } \\
\text { giving to para church }\end{array}$ \\
\hline
\end{tabular}




\begin{tabular}{|c|c|c|c|c|}
\hline & & & Jeyaraj (2004) & $\begin{array}{l}\text { loose everything for the sake of } \\
\text { the needy }\end{array}$ \\
\hline & & & Foster (1995) & lack of concern for others \\
\hline & & & $\begin{array}{l}\text { Ronsvalle and } \\
\text { Ronsvalle (2000) }\end{array}$ & Lack of vision affects giving. \\
\hline Institutional & $\begin{array}{l}\text { Increases in church } \\
\text { budget focus on } \\
\text { operational growth }\end{array}$ & 32 & $\begin{array}{l}\text { Ronsvalle and } \\
\text { Ronsvalle (1999) }\end{array}$ & $\begin{array}{l}\text { Churches focus on } \\
\text { self }\end{array}$ \\
\hline & & & $\begin{array}{l}\text { Luidens and } \\
\text { Nemeth (1994) }\end{array}$ & Giving toward internal purposes \\
\hline & & & Mead (1998) & Churches have turned inward \\
\hline & & & $\begin{array}{l}\text { Bibby cited in } \\
\text { Ronsvalle and } \\
\text { Ronsvalle (1996) }\end{array}$ & Become routine, grown inward \\
\hline Institutional & $\begin{array}{l}\text { Pastor feels } \\
\text { parishioners are } \\
\text { affected by } \\
\text { materialism and/or } \\
\text { consumerism } \\
\end{array}$ & 33 & Hubbard (2001) & 79\% say, I'd give more but.... \\
\hline & & & Webster (1984) & $\begin{array}{l}\text { Definitions of } \\
\text { materialism/Consumerism }\end{array}$ \\
\hline & & & Platt (2011) & likens materialism to war \\
\hline & & & Hubbard (2001) & Culture driven by "wants" \\
\hline & & & Wuthnow (1999) & $\begin{array}{l}\text { People don't think, they do not } \\
\text { budget }\end{array}$ \\
\hline & & & $\begin{array}{l}\text { Wilmer in } \\
\text { Ronsvalle and } \\
\text { Ronsvalle (1996) }\end{array}$ & $\begin{array}{l}\text { Church has not combated } \\
\text { materialism }\end{array}$ \\
\hline & & & $\begin{array}{l}\text { Ronsvalle and } \\
\text { Ronsvalle (1996) }\end{array}$ & $\begin{array}{l}\text { Discretionary income available } \\
\text { today }\end{array}$ \\
\hline & & & Wuthnow (1999) & $\begin{array}{l}\text { Faith should play a part in less } \\
\text { materialism }\end{array}$ \\
\hline & & & Russell (2002) & $\begin{array}{l}\text { toward possessions a spiritual } \\
\text { matter }\end{array}$ \\
\hline Institutional & $\begin{array}{l}\text { Pastor believes credit } \\
\text { card use is an issue for } \\
\text { members in his } \\
\text { congregation }\end{array}$ & 34 & $\begin{array}{l}\text { Woosley and } \\
\text { Schulz (2011) }\end{array}$ & statistics \\
\hline Institutional & $\begin{array}{l}\text { Pastor believes those } \\
\text { he perceives to be } \\
\text { generous people in his }\end{array}$ & 35 & Brooks (2006) & $\begin{array}{l}\text { Charity increases happiness, } \\
\text { health }\end{array}$ \\
\hline
\end{tabular}




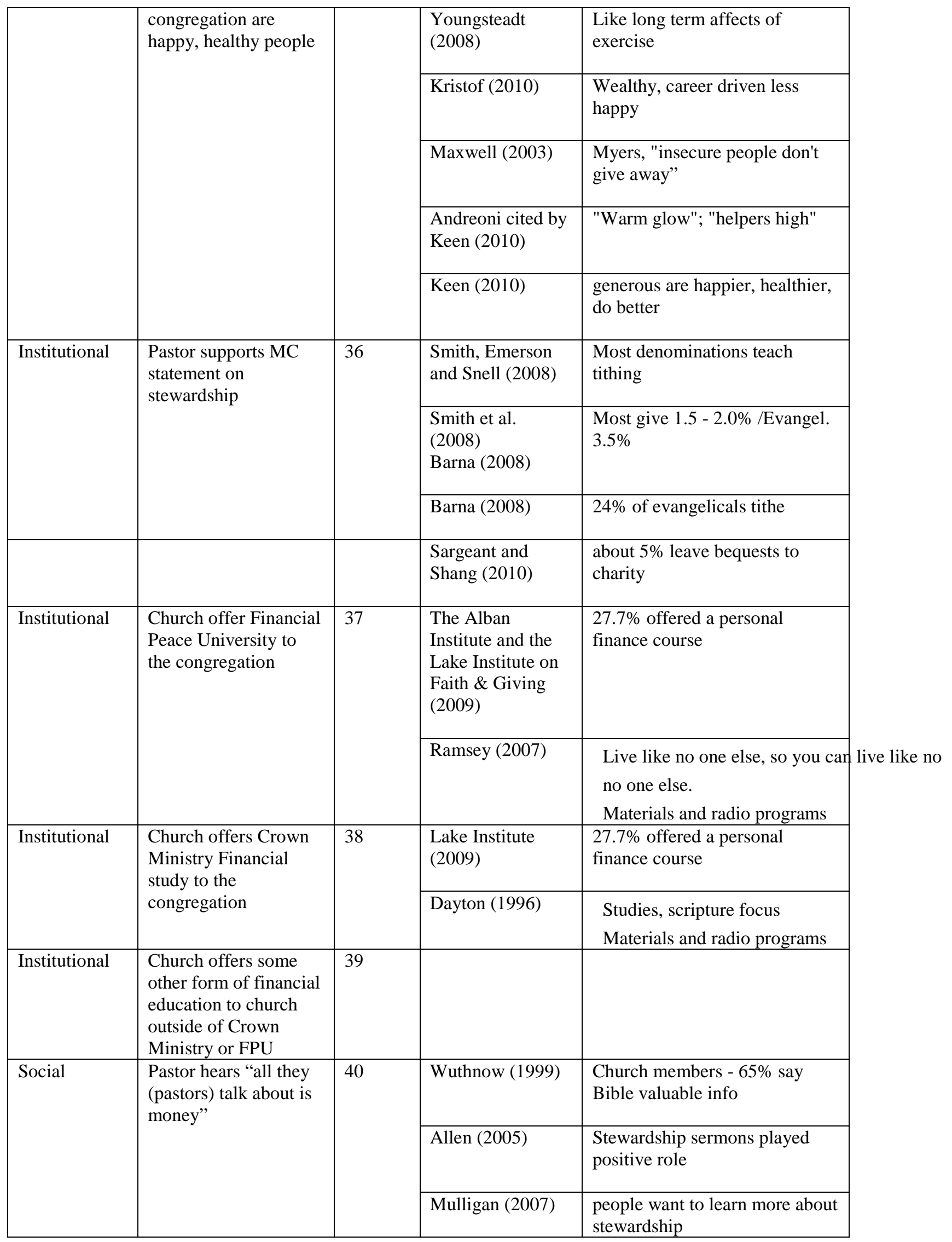




\begin{tabular}{|c|c|c|c|c|}
\hline & & & Alcorn (2001) & $\begin{array}{l}\text { connection between spirituality } \\
\text { and money }\end{array}$ \\
\hline & & & Roth (1987) & $\begin{array}{l}\text { All the church is interested in is } \\
\text { money }\end{array}$ \\
\hline \multirow[t]{5}{*}{ Social } & \multirow{5}{*}{$\begin{array}{l}\text { Pastor believes } \\
\text { consumer debt keeps } \\
\text { people from giving } \\
\text { more generously }\end{array}$} & \multirow[t]{5}{*}{41} & $\begin{array}{l}\text { Woosley and } \\
\text { Schulz (2011) }\end{array}$ & stats \\
\hline & & & $\begin{array}{l}\text { Ronsvalle and } \\
\text { Ronsvalle (1996) }\end{array}$ & $\begin{array}{l}\text { People are struggling } \\
\text { financially }\end{array}$ \\
\hline & & & Russell (2002) & $\begin{array}{l}\text { Money is a god for many } \\
\text { people }\end{array}$ \\
\hline & & & $\begin{array}{l}\text { Ronsvalle and } \\
\text { Ronsvalle (1996) }\end{array}$ & $\begin{array}{l}\text { The desire for more affluent } \\
\text { living }\end{array}$ \\
\hline & & & Wuthnow (1999) & $\begin{array}{l}\text { Pastors keenly aware of } \\
\text { pressures to buy }\end{array}$ \\
\hline \multirow[t]{3}{*}{ Social } & \multirow{2}{*}{$\begin{array}{l}\text { Pastor believes clergy } \\
\text { feel pressure to NOT } \\
\text { speak on financially } \\
\text { related topics }\end{array}$} & \multirow[t]{2}{*}{42} & Bagwell (1993) & people feel whipped, guilty \\
\hline & & & $\begin{array}{l}\text { Woosley and } \\
\text { Schulz(2011) }\end{array}$ & discussing debt is highly taboo \\
\hline & & & Wuthnow (1998) & $\begin{array}{l}\text { Family don't even discuss } \\
\text { money }\end{array}$ \\
\hline Social & $\begin{array}{l}\text { Pastor believes credit } \\
\text { card use is an issue for } \\
\text { members in his } \\
\text { congregation }\end{array}$ & 43 & $\begin{array}{l}\text { Woosley and } \\
\text { Schulz(2011) }\end{array}$ & stats \\
\hline & & & & \\
\hline
\end{tabular}




\section{APPENDIX E}

\section{FREQUENCY STATISTICS—INDEPENDENT VARIABLES}

Q19 - I am very comfortable preaching/teaching on financially related topics

\begin{tabular}{lrrcccc}
\hline & Freq. & \% & Valid \% & Cumul. \% & Mean & SD \\
\hline Str. Agree & 116 & 36.8 & 37.1 & 37.1 & 1.76 & .674 \\
Agree & 159 & 50.5 & 50.8 & 87.9 & & \\
Disagree & 36 & 11.4 & 11.5 & 99.4 & & \\
Str. Disagree & 2 & .6 & .6 & 100.0 & & \\
Total & 313 & 99.4 & 100.0 & & & \\
Missing & 2 & .6 & & & & \\
Total & 315 & 100.0 & & & & \\
& & & & & & \\
\hline
\end{tabular}

Q20 - I believe tithing is still applicable for today’s Christian

\begin{tabular}{lrrcccc}
\hline & Freq. & \% & Valid \% & Cumul. \% & Mean & SD \\
\hline Str. Agree & 242 & 76.8 & 77.8 & 77.8 & 1.27 & .553 \\
Agree & 58 & 18.4 & 18.6 & 96.5 & & \\
Disagree & 8 & 2.5 & 2.6 & 99.0 & & \\
Str. Disagree & 3 & 1.0 & 1.0 & 100.0 & & \\
Total & 311 & 98.7 & 100.0 & & & \\
Missing & 4 & 1.3 & & & & \\
Total & 315 & 100.0 & & & & \\
\hline
\end{tabular}

Q21 - I believe the tithe is meant to come directly to the church

\begin{tabular}{lrrcccc}
\hline & Freq. & \% & Valid \% & Cumul. \% & Mean & SD \\
\hline Str. Agree & 191 & 60.6 & 61.6 & 61.6 & 1.46 & .641 \\
Agree & 96 & 30.5 & 31.0 & 92.6 & & \\
Disagree & 22 & 7.0 & 7.1 & 99.7 & & \\
Str. Disagree & 1 & .3 & .3 & 100.0 & & \\
Total & 310 & 98.4 & 100.0 & & & \\
Missing & 5 & 1.6 & & & & \\
Total & 315 & 100.0 & & & & \\
& & & & & & \\
\hline
\end{tabular}


Q22 - I received biblical financial training as a part of my educational experience

\begin{tabular}{lrrcccc}
\hline & Freq. & \% & Valid \% & Cumul. \% & Mean & SD \\
\hline Str. Agree & 79 & 25.1 & 25.6 & 25.6 & 2.37 & 1.02 \\
Agree & 83 & 26.3 & 26.9 & 52.6 & & \\
Disagree & 100 & 31.7 & 32.5 & 85.1 & & \\
Str. Disagree & 46 & 14.6 & 14.9 & 100.0 & & \\
Total & 308 & 97.8 & 100.0 & & & \\
Missing & 7 & 2.2 & & & & \\
Total & 315 & 100.0 & & & & \\
& & & & & & \\
\hline
\end{tabular}

Q23 - I received biblical financial training since entering the ministry

\begin{tabular}{lrrrccl}
\hline & Freq. & \% & Valid \% & Cumul. \% & Mean & SD \\
\hline Str. Agree & 92 & 29.2 & 29.7 & 29.7 & 1.96 & .797 \\
Agree & 152 & 48.3 & 49.0 & 78.7 & & \\
Disagree & 53 & 16.8 & 17.1 & 95.8 & & \\
Str. Disagree & 13 & 4.1 & 4.2 & 100.0 & & \\
Total & 310 & 98.4 & 100.0 & & & \\
Missing & 5 & 1.6 & & & & \\
Total & 315 & 100.0 & & & & \\
& & & & & &
\end{tabular}

Q24 - I am willing to attend biblical financial training in the future

\begin{tabular}{lrrrccc}
\hline & Freq. & \% & Valid \% & Cumul. \% & Mean & SD \\
\hline Str. Agree & 111 & 35.2 & 35.5 & 35.5 & 1.74 & .629 \\
Agree & 172 & 54.6 & 55.0 & 90.4 & & \\
Disagree & 29 & 9.2 & 9.3 & 99.7 & & \\
Str. Disagree & 1 & .3 & .3 & 100.0 & & \\
Total & 313 & 99.4 & 100.0 & & & \\
Missing & 2 & .6 & & & & \\
Total & 315 & 100.0 & & & & \\
\hline
\end{tabular}


Q25 - I am comfortable with my current financial package

\begin{tabular}{lrrcccc}
\hline & Freq. & \% & Valid \% & Cumul. \% & Mean & SD \\
\hline Str. Agree & 61 & 19.4 & 20.0 & 20.0 & 2.14 & .793 \\
Agree & 156 & 49.5 & 51.1 & 71.1 & & \\
Disagree & 72 & 22.9 & 23.6 & 94.8 & & \\
Str. Disagree & 16 & 5.1 & 5.2 & 100.0 & & \\
Total & 305 & 96.8 & 100.0 & & & \\
Missing & 10 & 3.2 & & & & \\
Total & 315 & 100.0 & & & & \\
\hline
\end{tabular}

Q26 - Being liked by my congregation is important to me

\begin{tabular}{lrrcccc}
\hline & Freq. & \% & Valid \% & Cumul. \% & Mean & SD \\
\hline Str. Agree & 118 & 37.5 & 38.2 & 38.2 & 1.67 & .581 \\
Agree & 175 & 55.6 & 56.6 & 94.8 & & \\
Disagree & 15 & 4.8 & 4.9 & 99.7 & & \\
Str. Disagree & 1 & .3 & .3 & 100.0 & & \\
Total & 309 & 98.1 & 100.0 & & & \\
Missing & 6 & 1.9 & & & & \\
Total & 315 & 100.0 & & & & \\
& & & & & &
\end{tabular}

Q27 - My church is supportive of me

\begin{tabular}{lrrrccc}
\hline & Freq. & \% & Valid \% & Cumul. \% & Mean & SD \\
\hline Str. Agree & 183 & 58.1 & 58.3 & 58.3 & 1.44 & .558 \\
Agree & 125 & 39.7 & 39.8 & 98.1 & & \\
Disagree & 4 & 1.3 & 1.3 & 99.4 & & \\
Str. Disagree & 2 & .6 & .6 & 100.0 & & \\
Total & 314 & 99.7 & 100.0 & & & \\
Missing & 1 & .3 & & & & \\
Total & 315 & 100.0 & & & & \\
\hline
\end{tabular}


Q28 - I believe the pastor should know the giving records of those who attend their church

\begin{tabular}{lrrrccc}
\hline & Freq. & \% & Valid \% & Cumul. \% & Mean & SD \\
\hline Str. Agree & 73 & 23.2 & 23.6 & 23.6 & 2.49 & 1.05 \\
Agree & 70 & 22.2 & 22.7 & 46.3 & & \\
Disagree & 107 & 34.0 & 34.6 & 80.9 & & \\
Str. Disagree & 59 & 18.7 & 19.1 & 100.0 & & \\
Total & 309 & 98.1 & 100.0 & & & \\
Missing & 6 & 1.9 & & & & \\
Total & 315 & 100.0 & & & & \\
& & & & & & \\
\hline
\end{tabular}

Q29 - I am aware of the individual giving records of those in my congregation

\begin{tabular}{lrrcccc}
\hline & Freq. & \% & Valid \% & Cumul. \% & Mean & SD \\
\hline Yes & 77 & 24.4 & 24.5 & 24.5 & 1.98 & .687 \\
No & 166 & 52.7 & 52.9 & 77.4 & & \\
Some not all & 71 & 22.5 & 22.6 & 100.0 & & \\
Total & 314 & 99.7 & 100.0 & & & \\
Missing & 1 & .3 & & & & \\
Total & 315 & 100.0 & & & & \\
& & & & & & \\
\hline
\end{tabular}

Q30 - I feel pressure in my church to not talk about money

\begin{tabular}{lrrrccl}
\hline & Freq. & \% & Valid \% & Cumul. \% & Mean & SD \\
Str. Agree & 8 & 2.5 & 2.6 & 2.6 & 3.25 & .717 \\
Agree & 27 & 8.6 & 8.6 & 11.2 & & \\
Disagree & 157 & 49.8 & 50.2 & 61.3 & & \\
Str. Disagree & 121 & 38.4 & 38.7 & 100.0 & & \\
Total & 313 & 99.4 & 100.0 & & & \\
Missing & 2 & .6 & & & & \\
Total & 315 & 100.0 & & & & \\
& & & & & & \\
\hline
\end{tabular}


Q31 - Annual increases in our church budget mostly address outreach efforts

\begin{tabular}{lrrcccl}
\hline & Freq. & \% & Valid \% & Cumul. \% & Mean & SD \\
\hline Str. Agree & 36 & 11.4 & 11.7 & 11.7 & 2.37 & .740 \\
Agree & 132 & 41.9 & 43.0 & 54.7 & & \\
Disagree & 127 & 40.3 & 41.4 & 96.1 & & \\
Str. Disagree & 12 & 3.8 & 3.9 & 100.0 & & \\
Total & 307 & 97.5 & 100.0 & & & \\
Missing & 8 & 2.5 & & & & \\
Total & 315 & 100.0 & & & & \\
& & & & & & \\
\hline
\end{tabular}

Q32 - Annual increases in our church budget mostly address operational expenses

\begin{tabular}{lrrcccl}
\hline & Freq. & \% & Valid \% & Cumul. \% & Mean & SD \\
Str. Agree & 32 & 10.2 & 10.6 & 10.6 & 2.24 & .666 \\
Agree & 172 & 54.6 & 56.8 & 67.3 & & \\
Disagree & 92 & 29.2 & 30.4 & 97.7 & & \\
Str. Disagree & 27 & 2.2 & 2.3 & 100.0 & & \\
Total & 303 & 96.2 & 100.0 & & & \\
Missing & 12 & 3.8 & & & & \\
Total & 315 & 100.0 & & & & \\
& & & & & & \\
\hline
\end{tabular}

Q33 - I believe materialism/consumerism affects those in my congregation

\begin{tabular}{lrrcccc}
\hline & Freq. & \% & Valid \% & Cumul. \% & Mean & SD \\
Str. Agree & 92 & 29.2 & 29.8 & 29.8 & 1.89 & .712 \\
Agree & 164 & 52.1 & 53.1 & 82.8 & & \\
Disagree & 48 & 15.2 & 15.5 & 98.4 & & \\
Str. Disagree & 5 & 1.6 & 1.6 & 100.0 & & \\
Total & 309 & 98.1 & 100.0 & & & \\
Missing & 6 & 1.9 & & & & \\
Total & 315 & 100.0 & & & & \\
& & & & & & \\
\hline
\end{tabular}


Q34 - Credit card debt is an issue in my church

\begin{tabular}{lrrcccc}
\hline & Freq. & \% & Valid \% & Cumul. \% & Mean & SD \\
\hline Str. Agree & 64 & 20.3 & 21.0 & 21.0 & 2.03 & .699 \\
Agree & 174 & 55.2 & 57.0 & 78.0 & & \\
Disagree & 61 & 19.4 & 20.0 & 98.0 & & \\
Str. Disagree & 6 & 1.9 & 2.0 & 100.0 & & \\
Total & 305 & 96.8 & 100.0 & & & \\
Missing & 10 & 3.2 & & & & \\
Total & 315 & 100.0 & & & & \\
\hline
\end{tabular}

Q35 - Those in my congregation who are the most generous are the most happy

\begin{tabular}{lrrrccc}
\hline & Freq. & \% & Valid \% & Cumul. \% & Mean & SD \\
\hline Str. Agree & 112 & 35.6 & 36.6 & 36.6 & 1.70 & .585 \\
Agree & 174 & 55.2 & 56.9 & 93.5 & & \\
Disagree & 20 & 6.3 & 6.5 & 100.0 & & \\
Str. Disagree & 0 & .0 & .0 & & & \\
Total & 306 & 97.1 & 100.0 & & & \\
Missing & 9 & 2.9 & & & & \\
Total & 315 & 100.0 & & & & \\
& & & & & &
\end{tabular}

Q36 - I support the Missionary Church's statement on stewardship

\begin{tabular}{lrrrccl}
\hline & Freq. & \% & Valid \% & Cumul. \% & Mean & SD \\
\hline Str. Agree & 152 & 48.3 & 49.5 & 49.5 & 1.52 & .526 \\
Agree & 151 & 47.9 & 49.2 & 98.7 & & \\
Disagree & 4 & 1.3 & 1.3 & 100.0 & & \\
Str. Disagree & 0 & .0 & .0 & & & \\
Total & 307 & 97.5 & 100.0 & & & \\
Missing & 8 & 2.5 & & & & \\
Total & 315 & 100.0 & & & & \\
& & & & & &
\end{tabular}


Q37 - My Church offers Financial Peace University as an option of study for our congregation

\begin{tabular}{lrrrcrl}
\hline & Freq. & \% & Valid \% & Cumul. \% & Mean & SD \\
\hline Yes & 134 & 42.5 & 44.4 & 44.4 & .556 & .490 \\
No & 168 & 53.3 & 55.6 & 100.0 & & \\
Total & 302 & 95.9 & 100.0 & & & \\
Missing & 13 & 4.1 & & & & \\
Total & 315 & 100.0 & & & & \\
& & & & & & \\
\hline
\end{tabular}

Q38 - My church offers Crown Ministry as an option of study for our congregation

\begin{tabular}{lcrcccc}
\hline & Freq. & \% & Valid \% & Cumul. \% & Mean & SD \\
\hline Yes & 105 & 33.3 & 34.5 & 34.5 & .655 & .476 \\
No & 199 & 63.2 & 65.5 & 100.0 & & \\
Total & 304 & 96.5 & 100.0 & & & \\
Missing & 11 & 3.5 & & & & \\
Total & 315 & 100.0 & & & & \\
& & & & & & \\
\hline
\end{tabular}

Q39 - My church offers some other form of financial training to our congregation

\begin{tabular}{lrrrccc}
\hline & Freq. & \% & Valid \% & Cumul. \% & Mean & SD \\
\hline Yes & 70 & 22.2 & 24.3 & 24.3 & .757 & .430 \\
No & 218 & 69.2 & 75.7 & 100.0 & & \\
Total & 288 & 91.4 & 100.0 & & & \\
Missing & 27 & 8.6 & & & & \\
Total & 315 & 100.0 & & & & \\
** See list below of options offered & & & & \\
\end{tabular}


Q40 - Society believes all pastors do is talk about money

\begin{tabular}{lrrcccc}
\hline & Freq. & \% & Valid \% & Cumul. \% & Mean & SD \\
Str. Agree & 38 & 12.1 & 12.4 & 12.4 & 2.29 & .698 \\
Agree & 147 & 46.7 & 48.0 & 60.5 & & \\
Disagree & 116 & 36.8 & 37.9 & 98.4 & & \\
Str. Disagree & 5 & 1.6 & 1.6 & 100.0 & & \\
Total & 306 & 97.1 & 100.0 & & & \\
Missing & 9 & 2.9 & & & & \\
Total & 315 & 100.0 & & & & \\
& & & & & & \\
\hline
\end{tabular}

Q41 - I believe consumer debt affects people’s ability to give more generously

\begin{tabular}{lrrrccc}
\hline & Freq. & \multicolumn{1}{c}{ \% } & Valid \% & Cumul. \% & Mean & SD \\
\hline Str. Agree & 140 & 44.4 & 45.3 & 45.3 & 1.60 & .592 \\
Agree & 152 & 48.3 & 49.2 & 94.5 & & \\
Disagree & 17 & 5.4 & 5.5 & 100.0 & & \\
Str. Disagree & 0 & .0 & .0 & & & \\
Total & 309 & 98.1 & 100.0 & & & \\
Missing & 6 & 1.9 & & & & \\
Total & 315 & 100.0 & & & & \\
& & & & & & \\
\hline
\end{tabular}

Q42 - Society believes all pastors do is ask for money

\begin{tabular}{lrrcccc}
\hline & Freq. & \% & Valid \% & Cumul. \% & Mean & SD \\
\hline Str. Agree & 37 & 11.7 & 12.1 & 12.1 & 2.28 & .692 \\
Agree & 151 & 47.9 & 49.2 & 61.2 & & \\
Disagree & 114 & 36.2 & 37.1 & 98.4 & & \\
Str. Disagree & 5 & 1.6 & 1.6 & 100.0 & & \\
Total & 307 & 97.5 & 100.0 & & & \\
Missing & 8 & 2.5 & & & & \\
Total & 315 & 100.0 & & & & \\
& & & & & & \\
\hline
\end{tabular}


Q43 - Credit card debt is an issue in our society

\begin{tabular}{lrrrccc}
\hline & Freq. & \% & Valid \% & Cumul. \% & Mean & SD \\
\hline Str. Agree & 241 & 76.5 & 78.0 & 78.0 & 1.22 & .434 \\
Agree & 66 & 21.0 & 21.4 & 99.4 & & \\
Disagree & 2 & .6 & .6 & 100.0 & & \\
Str. Disagree & 0 & .0 & .0 & & & \\
Total & 309 & 98.1 & 100.0 & & & \\
Missing & 6 & 1.9 & & & & \\
Total & 315 & 100.0 & & & & \\
\hline
\end{tabular}

** The following were provided as responses for question 39 as other financial studies offered to local congregations

\author{
Survey \\ Resp. Num. Offer Congregation \\ 1 Church offers study through church deacons \\ $7 \quad$ MMA reps and materials \\ 8 Everence \\ 9 Some Everence (MMA) training \\ 10 One Time Dave Ramsey (Financial Peace University) class \\ 13 I was broke; now I am not (Joe Sangl) \\ $17 \quad$ Good Sense \\ 23 Good Sense Budget Course \\ 30 Manage Your Finances God's Way (Saddleback Church) \\ $34 \quad$ We plan our own classes \\ $41 \quad$ Own financial ministry \\ 52 Cualquier Irma Seria y responsible \\ 68 Financialuid \\ $69 \quad$ Financial Servinary \\ $70 \quad$ Financial Crown \\ $85 \quad$ Good Sense (Willow Creek) \\ 88 Bible Studies \\ 103 Cualquier plan logico que ayude \\ $151 \quad$ My Own Training \\ 154 Treasure Principle \\ 168 A series we created \\ 177 Good Sense \\ 198 Classes using Crown, et al at a time \\ 223 Good Sense \\ $240 \quad$ Paz Financiere \\ 267 Burkett - Financial course from local Christian University \\ $268 \quad$ Counseling by Pastor \& Association \\ 271 Sunday School and Everence
}


The following surveys note they offer other than Crown or Financial Peace University but did not list what they offer: 27, 44, 45, 48, 50, 51, 54, 55, 57, 59, 60, 63, 65, 66, 90, 91, 95, 96, 100, 101, 102, 106, 107, 109, 110, 148, 153, 155, 170, 189, 190, 235, 237, 239, 279, 280, 281 and 306 


\section{Andrews $\mathbf{Q}$ University}

School of Education

\section{Informed Consent Letter for Preaching/Teaching Pastor Pastoral Demographic, Personal, Institutional, and Social Factors Associated With Preaching or Teaching Financially Related Topics Within The Missionary Church}

This exercise has been approved by the Missionary Church and is for the purpose of gathering data for a dissertation research project. This process of gathering information will be conducted at each district conference meeting.

Each participant will be given a copy of the informed consent letter, a survey instrument and an envelope. The survey should take between 5-10 minutes to complete. Once completed, the participant is asked to place their survey in the envelope provided, seal it and turn it in to the designated survey collector.

Purpose of Study: I understand that the purpose of this questionnaire is to identify independent variables in the areas of demographic, personal, institutional and social characteristics that influence pastors within the Missionary Church to preach and teach on financially related topics.

Inclusion Criteria: I have been informed that in order to participate, I must be an adult 18 years or older, of sound mind, and must be the main preaching/teaching pastor in my church.

Risks and Discomforts: I have been informed that there is minimal is any physical or emotional risks to my involvement in this study.

Benefits/Results: I have been informed and now I accept that I will receive no remuneration for my participation, but that by participating, I will help the researcher arrive at a better understanding of variables that encourage pastors to address financially related topics.

Voluntary Participation: I have been informed and understand that my involvement in this survey is voluntary and that I may withdraw my participation at any time without any pressure, embarrassment, or negative impact on me. I also understand that participation is anonymous and that neither the researcher nor any assistants will be able to identify my responses to me.

Contact Information: I have been informed that in the event that I have any questions or concerns with regard to my participation in this research project, I understand that I 
may contact either the researcher, Terry Zeitlow at terry.zeitlow@bethelcollege.edu (Tel: (574) 257-3311), or his advisor, Dr. Duane Covrig, professor in Leadership at covrig@andrews.edu (Tel: (269) 471-3475). I may retain this email for my own records.

I have read and understand the content of the informed consent and I am willing to participate in this study. I hereby append my signature as evidence and consent to my participation

Participants Signature

\begin{tabular}{ccc} 
Date: & 1 & 1 \\
\hline Date & 1 & 1
\end{tabular}

Terry A Zeitlow: Investigator 


\section{Andrews $\$$ University}

Escuela de Educación

\section{Forma de consentimiento para profesores y pastores \\ Factores demográficas, personales, institucionales, y sociales asociadas con predicación y ensenanza en temas financieras en la Iglesia Misionera}

Este ejercicio a sido aprobado por la Iglesia Misionera para obtener datos para una inversigación de una tesis doctoral. Este proceso sera conducido en una asamblea en cada distrito.

Cada participante sera dada una copia de la forma de consentimiento, un instrumento de encuesta, y un sobre. La encuesta se puede completer en cinco a diez minutos. Al completer la encuesta, se les solicita a los participantes que pongan sus encuenstas en los sobres, las cuales deben sellar y retornar al colectador de encuestas.

Propósito del estudio: Comprendo que el propósito de este cuestionario es identificar variables demográficas, personales, institutionales, y sociales que influyan la manera en que pastores de la Iglesia Misionera predican y enseñan sobre temas financieras.

Criterio de inclusión: Reconozco que participantes deben tener por lo menos 18 años de edad, ser de mente sana, y ser el pastor principal de una Iglesia Misionera.

Riezgos: He sido informado de que no hay riezgos físicos o emocionales en mi participación en este estudio.

Beneficios/Resultados: Acepto que no recibiré remuneración por mi participación, pero que mi participación ayudará a mejorar el entendimiento de variables que animan a pastores a predicar sobre temas financieras.

Participación: Entiendo que mi involucración en esta encuesta es voluntario y que puedo retirarme en cualquier momento sin impacto negative alguno. Entiendo también que mi participación sera anónima y que ni el investigador ni sus asistentes van a poder identificarme en relación a mis respuestas.

Fuente de información: En el evento de que yo tenga preguntas sobre mi participación en este proyecto, entiendo que puedo contacatar al investigador, Terry Zeitlow al correo electrónico terry.zeitlow@bethelcollege.edu (Tel: (574) 257-3311) o su ayudante, Dr. Duane Covrig, profesor de liderazgo, al correo covrig@andrews.edu (Tel: (269) 4713475). Puedo retener esta informacion para mis archivos. 
He leido y entendido el contenido de la forma de consentimiento y estoy dispuesto a participar en este estudio. Confirmo con mi firma que doy mi consentimiento para mi participación.

Firma del Participante

Terry A Zeitlow: Investigador

Fecha:

Fecha: 


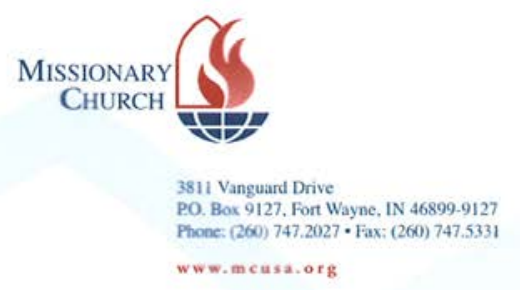

June 16, 2011

Andrews University Institutional Review Board 4150 Administration Drive Berrien Springs MI 49104

To Whom It May Concern:

The Missionary Church, Inc. is supportive and willing to participate in the study "Pastoral Demographic, Personal, Institutional and Social Factors Associated With Preaching and Teaching Financially Related Topics Within the Missionary Church, Inc." as part of a PhD dissertation being performed by Terry Zeitlow at Andrews University. Our willingness to participate is pending Andrews University IRB approval.

We understand the instrument to be used is a survey questionnaire to be voluntarily administered at district conference meetings between November 2011 and June 2012 to senior preaching pastors within our denomination. We also understand if we have any questions or concerns we can contact your IRB offices, Terry Zeitlow at terry.zeitlow@bethelcollege.edu or 574 204-3675 or his dissertation Chair, Dr. Duane Covrig at covrig@andrews.edu or 269 471-3475.

We look forward to working with Terry during this dissertation phase and to the useful information this study will provide.

\section{Sincerely,}

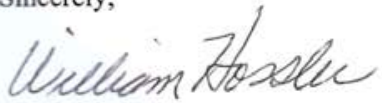

Dr. William A. Hossler, President Missionary Church, Inc. 


\section{Andrews $\$$ University}

August 19, 2011

Terry Zeitlow

Tel: 574-204-3675

Email: terry.zeitlow@bethelcollege.edu

\section{RE: APPLICATION FOR APPROVAL OF RESEARCH INVOLVING HUMAN SUBJECTS}

IRB Protocol \#: 11-122 Application Type: Original Advisor: Duane Covrig Dept.: Leadership

Preaching or Teaching Financially Related Topics Within the Missionary Church, Inc.

Your IRB application for research involving human subjects entitled: "Pastoral Demographic, Personal, Institutional and Social Factors Associated with Preaching or Teaching Financially Related Topics Within the Missionary Church, Inc.” IRB protocol \# 11-122 has been evaluated and determined to be Exempt under category 46.101 (b) (2). You may now proceed with your research.

We ask that you reference the protocol number in any future correspondence regarding this study for easy retrieval of information.

Please note that any future changes made to the study design and/or consent form require prior approval from the IRB before such changes can be implemented.

While there appears to be no risks with your study, should an incidence occur that results in a research-related adverse reaction and/or physical injury, this must be reported immediately in writing to the IRB. Any research-related physical injury must also be reported immediately to the University Physician, Dr. Hamel, by calling (269) 473-2222.

Please feel free to contact our office if you have any questions.

All the best in your research.

Sincerely,

Sarah Kimakwa

IRB, Research \& Creative Scholarship

Tel: 269-471-6361 Fax: 269-471-6246

IRB email: irb@andrews.edu

Institutional Review Board

Tel: (269) 471-6361 Fax: (269) 471-6543 E-mail: irb@andrews.edu Andrews University, Berrien Springs, MI 49104-0355 


\section{REFERENCE LIST}

The Alban Institute and the Lake Institute on Faith \& Giving. (2009). 2009

Congregational economic impact study. Indianapolis, IN: Center on Philanthropy at Indiana University.

Alcorn, R. (2001). The treasure principle. Sisters, OR: Multnomah.

Allen, R. J. (2005, September). Preach money from the pulpit: Laity give their views on stewardship sermons. The Clergy Journal, 3-5.

Bagwell, T. J. (1993). Preaching for giving: Proclaiming financial stewardship with holy boldness. Nashville, TN: Discipleship Resources.

Bailey, R. (1993). A revisitation of the WISC-R factor structure with adequate sample size, systematic control of both IQ and age ranges, and the use of procedures to limit overfactorization (Doctoral dissertation). Available from ProQuest Dissertations and Theses database. (AAT 9334291)

Barna G. (2008). New study shows trends in tithing and donating. Retrieved September 19, 2010, from http://www.barna.org/congregations-articles/41-new-studyshows- trends-in-tithing-and-donations.

Bedell, K. (1993). Yearbook of American and Canadian churches 1993. Nashville, TN: Abingdon Press.

Blowers, L. P. (2012). The Wesleyan tradition: Who we are, what we believe, and who we serve. In Reflections (pp. 38-64). Mishawaka, IN: Missionary Church Historical Society.

Brauer, M. (n.d.). Factor analysis (FA). Retrieved October 14, 2012, from http://lapsco.univ-bpclermont.fr/persos/brauer/pdf/HO\%20Factor\%20analysis.pdf

Brooks, A. C. (2006). Who really cares: American charity divide, who gives, who doesn't, and why it matters. New York, NY: Basic Books.

Burkholder, J. S. (2012). The persistent legacy of "heart religion": An introduction to the pietist tradition. In Reflections (pp. 29-37). Mishawaka, IN: Missionary Church Historical Society. 
Collett, J. L., \& Morrissey, C. A. (2007). The social psychology of generosity: The state of current interdisciplinary research. Retrieved February 11, 2011, from http://generosityresearch.nd.edu/assets/17634/social_psychology_of_generosity_f inal.pdf.

Consumerism. (1984). Websters ninth new collegiate dictionary. Springfield, MA: Merriam-Webster.

Costello, A. B., \& Osborne, J. W. (2005). Best practices in exploritory factor analysis: Four recommendations for getting the most from your analysis. Practical Assessment, Research \& Evaluation, 10(7), 1-9.

Creswell, J. W. (2008). Educational research: Planning, conducting, and evaluating quantitative and qualitative research. Upper Saddle River, NJ: Pearson Merrill Prentice Hall.

Crown Financial Ministries. (2003). Biblical financial study: Small group student manual. Gainesville, GA: Author.

Davidson, J. D., \& Pyle, R. E. (1994, December). Passing the plate in affluent churches: Why some members give more than others. Review of Religious Research, 181196.

Dayton, H. (1996). Your money counts. Gainsville, GA: Crown Financial Ministries.

Donahue, M. J. (1994). Correlates of religious giving in six Protestant denominations. Review of Religious Research, 36(2), 149-157.

Engbrecht, D., \& Erdel, T. (2003, December 2-3). An overview of the Missionary Church, Inc. Council of Moderates \& Secretaries [Conference], Akron, PA.

Erdel, T. P. (1997). Five theological traditions which gave rise to and guide the Missionary Church and Bethel College. Course handout, unpublished. Bethel College, Mishawaka, IN.

Erdel, T. P. (2012). The evangelical tradition in the Missionary Church: Enduring debts and unresolved dilemmas. In Reflections (pp. 74-109). Chicago, IL: Missionary Church Historical Society.

Falk, E., Raybin, N. L., \& Rooney, P.M. (2010). Giving USA 2010: The annual report on philanthropy for the year 2009. Indianapolis, IN: The Center on Philanthropy at Indiana University.

Field, A. P. (2000). Discovering statistics using SPSS for windows. London: Sage. 
Field, A. P. (2005). Factor analysis using SPSS. In A. P. Field (Ed.), Discovering statistics using SPSS (pp. 1-14). London: Sage.

Field, A. P. (2009). Discovering statistics using SPSS. London: Sage.

Finke, R., Bahr, M., \& Scheitle, C. P. (2006). Toward explaining congregational giving. Social Science Research, 35, 620-641.

Foster, R. A. (1995). Stewardship: Sign and substance of the Christian life as taught in the New Testament. Southwestern Journal of Theology, 15-22.

Frederick, H., Tak, S., Kim, S.J., McDermott, M., \& Kou, X. (2009). Understanding donors' motivations. Indanapolis, IN: The Center on Philanthropy at Indiana University.

Freedman, S. G. (2010, September 25). Congregations reeling from decline in donations. Retrieved March 3, 2011, from Science of Generosity, http://www.nytimes.com/2010/09/25/us/25religion.html?_r=1

Glasow, P. A. (2005). Fundamentals of survey research methodology. McLean, VA: MITRE, Washington C3 Center.

Green, S. B., \& Salkind, N. J. (2011). Using SPSS for windows and macintosh: Analyzing and understanding data. Upper Saddle River, NJ: Pearson Education.

Hoge, D. (1994). Introduction: The problem of understanding church giving. Review of Religious Giving, 36(2), 101-110.

Hoge, D. (1995, Spring). Explanations for current levels of religious giving. In C. H. Hamilton \& W. F. Iichman (Eds.), Cultures of giving: How region and religion influence philanthropy (pp. 51-69). San Francisco, CA: Jossey-Bass.

Hoge, D., \& Yang, F. (1994). Determinants of religious giving in American denominations: Data from two nationwide surveys. Review of Religious Research, 123-148.

Hoge, D. R., Zech, C., McNamara, P., \& Donahue, M. J. (1996). Money matters: Personal giving in American churches. Louisville, KY: Westminster John Knox Press.

Hoge, D. R., McNamara, P., \& Zech, C. (1997). Plain talk about churches and money. Herndon, VA: The Alban Institute. 
Hoge, D. R., Zech, C., McNamara, P., \& Donahue, M. J. (1999). Giving in five denominations. In M. Chaves \& S. L. Miller (Eds.), Financing American religion (pp. 3-9). London: Alta Mira Press.

Hubbard, R. L. (2001, March/April). The art of giving well. Moody, 18-21.

Iannaccone, L. R. (1997). Skewness explained: A rational choice model of religious giving. Journal for the Scientific Study of Religion, 36(2), 141-157.

Inskeep, K. W. (1994). Giving trends in the Evangelical Lutheran Church in America. Review of Religious Research, 36(2), 238-244.

Jacquet, C. H., Jr. (1973). Yearbook of American and Canadian churches 1973. Nashville, TN: Abingdon Press.

Jacquet, C. H., Jr. (1983). Yearbook of American and Canadian churches 1983. Nashville, TN: Abingdon Press.

Jeyaraj, J. B. (2004, April). Charity and stewardship: Biblical foundations. Evangelical Review of Theology, 28(2),166-173.

Keen, J. (2010, November 29). Unraveling the mystery of why we give, or don't. Retrieved March 11, 2011, from Science of Generosity: http://www.usatoday.com/yourlife/mind-soul/doing-good/2010-11-29-sharingwhat-makes-us-give_N.htm

Kluth, B. (1998). Maximizing generosity in churches: 20 financial \& generosity facts impacting churches. Colorado Springs, CO: Maximum Generosity.

Kostlevy, W. (2012). Conquerors after all: Keswick-A misunderstood tradition. In Reflections (pp. 65-73). Mishawaka, IN: Missionary Church Historical Society.

Kristoff, N. D. (2010, January 17). Our basic human pleasures: Food, sex and giving. Retrieved March 3, 2011, from Science of Generosity, http://www.nytimes.com/2010/01/17/opinion/17kristof.html/?_r=1

Lindner, E. W. (2003). Yearbook of American and Canadian churches 2003. Nashville, TN: Abingdon Prress.

Lindner, E. W. (2012). Yearbook of American and Canadian churches 2012. Nashville, TN: Abingdon Press.

Luidens, D. A., \& Nemeth, R. J. (1994). Social sources of family contributions: Giving patterns in the Reform Church in America. Review of Religious Research, 36(2), 207-217. 
Lunn, J., Klay, R., \& Douglass, A. (2001). Relationships among giving, church attendance, and religious belief: The case of the Presbyterian Church (USA). Journal for the Scientific Study of Religion, 40(4), 765-775.

Materialism. (1984). Websters ninth new collegiate dictionary. Springfield, MA: Merriam-Webster.

Maxwell, J. C. (2003). Leadership promises for every day. Nashville, TN: J. Countryman.

Mead, L. B. (1998). Financial meltdown in the mainline? Herndon, VA: The Alban Institute.

Mesch, D. J. (2010). Women give 2010: New research about women and giving. Indianapolis, IN: Women's Philanthropy Institute, Center of Philanthropy at Indiana University.

Miller, R. J., Parfet, R. A., \& Zech, C. (2001). The impact of stewardship programs on relgious giving: An empirical analysis of Catholic Parishes. Journal of Ministry Marketing \& Management, 7(1), 43-60.

Miller, S. L. (1999). The meaning of religious giving. In M. Chaves \& S. L. Miller (Eds.), Financing American religion (pp. 37-45). London: Alta Mira Press.

Missionary Church. (2012). Missionary church directory. Fort Wayne, IN: Author.

Missionary Church Articles of Practice. (n.d.) Retrieved January 28, 2011, from http://www.mcusa.org/AboutMC/PositionPapers/ArticlesofFaithandPractice.aspx \#Stewardship

Missionary Church Purpose Statement. (n.d.) Retrieved January 28, 2011, from http://www.mcusa.org/Portals/8/Documents/CONST11-8-5-11a.pdf

Mulder, J. M. (1999). Faith and money: Theological reflections on financing American religion. In M. Chaves \& S. L. Miller (Eds.), Financing American religion (pp. 157-167). London: Alta Mira Press.

Mulligan, M. A. (2007, September). Laity invite bolder preaching about stewardship. The Clergy Journal, 19-20.

Nemeth, R. J., \& Luidens, D. A. (1994). Congregational vs. denominational giving: An analysis of giving patterns in the Presbyterian Church in the United States and the Reformed Church in America. Review of Religious Research, 36(2), 111-122.

The NIV Study Bible. (1985). Grand Rapids, MI: Zondervan. 
Noll, M. A. (2007). The logic of evangelicalism and the challenges of philanthropy. Indianapolis, IN: Lake Institute on Faith \& Giving.

Nunnaly, J. (1978). Psychometric theory. New York, NY: McGraw-Hill.

Olson, D. V., \& Perl, P. (2005). Free and cheap riding in strict, conservative churches. Journal for the Scientific Study of Religion, 123-142.

Patten, M. L. (2001). Questionnaire research: A practical guide (2 ${ }^{\text {nd }}$ ed.). Los Angeles, CA: Pyrczak Publishing.

Platt, D. (2011). Radical: Taking back your faith from the American dream. Colorado Springs, CO: Multnomah Books.

Ramsey, D. (2007). The total money makeover: A proven plan for financial fitness. Nashville, TN: Thomas Nelson.

Rietveld, T., \& Van Hout, R. (1993). Statistical techniques for the study of language and language behaviour. New York, NY: Mouton de Gruyter.

Ronsvalle, J., \& Ronsvalle, S. (1996). Behind the stained glass windows. Grand Rapids, MI: Baker Books.

Ronsvalle, J., \& Ronsvalle, S. (1999). Basic trends in religious giving 1921-1995. In M. Chaves \& S. L. Miller (Eds.), Financing American religion (pp. 11-19). London: Alta Mira Press.

Ronsvalle, J. L., \& Ronsvalle, S. (2000). The state of church giving through 2000. Champaign, IL: Empty Tomb.

Roth, J. D., \& Nolt, S. M. (2012). The Anabaptist tradition. In Reflections (pp. 10-28). Mishawaka, IN: Missionary Church Historical Society.

Roth, R. (1987, August 3-7). Equipping the believers as stewards. Forty-ninth Biennial Convension. Northwestern College [Conference], Watertown, WI.

Rudenstam, K. E., \& Newton, R. R. (2007). Surviving your dissertation ( $3^{\text {rd }}$ ed.). Thousand Oaks, CA: Sage.

Russell, B. (2002, Fall). Preaching past the fear factor. Leadership, 42-46.

Santos, J. R. (1999, April). Cronbach's alpha: A tool for assessing the reliability of scales. Tools of the Trade, 37(2), 1-4.

Sargeant, A., \& Shang (2010). Envisioning a legacy. Philanthropy Matters, 18(1), 4-5. 
Schervish, P.G., \& Havens, J.J. (1997). Social participation and charitable giving: A multivariate analysis. Voluntas, 8(3), 235-260.

Schulz, T. A. (2001, October 23-25). The pastor as stewardship leader. ArizonaCalifornia Pastoral Conference [Conference], Apache Junction, AZ.

Smith, C., Emerson, M. O., \& Snell, P. (2008). Passing the plate: Why American Christians don't give away more money. New York, NY: Oxford University Press.

SPSS FAQ: What does Cronbach's alpha mean? (n.d.). Retrieved September 8, 2012, from http://www.ats.ucla.edu/stat/spss/faq/alpha/html

Starks, B., \& Smith, C. (2013). Unleashing Catholic generosity: Explaining the Catholic giving gap in the United States. South Bend, IN: University of Notre Dame Institute for Church Life.

Stowell, J. M. (1987, Winter Quarter). Putting it on the line: Teaching people to give. Leadership, 22-26.

Schwarz, J. (2011, March). Research methodology: Tools applied data analysis. Retrieved October 10, 2012, from Lecture 03: Factor Analysis, http://www.schwarzpartners.ch/Applied Data Analysis/Lect\%2003 EN.pdf

Tabachnick, B., \& Fidell, L. (2001). Using multivariate statistics ( $4^{\text {th }}$ ed.). Needham Heights, MA: Allyn \& Bacon.

Tavakol, M., \& Dennick, R. (2011). Making sense of Cronbach's alpha. International Journal of Medical Education, 2, 53-55.

Wilhelm, M. O., Rooney, P. M., \& Tempel, E. R. (2007). Changes in religious giving reflect changes in involvement: Age and cohort effects in religious giving, secular giving and attendance. Journal for the Scientific Study and Religion, 46(2), 217232.

Willmer, W. K. (1995, Spring). Evangelicals: Linking fervency of faith and generosity of giving. New Direction for Philanthropic Fundraising, 101-115.

Woosley, B., \& Schulz, M. (2011). Credit card statistics, industry facts, debt statistics. Retrieved February 22, 2011, from http://www.creditcards.com/credit-cardnews/credit-card-industry-facts-personal-debt-statistics-1276.php

Wuthnow, R. (1997). The crisis in the churches: Spiritual malaise, fiscal woe. Oxford: Oxford University Press. 
Wuthnow, R. (1999). The crisis in the churches. In M. Chaves \& S. L. Miller (Eds.), Financing American religion (pp. 67-76). London: AltaMira Press.

Youngsteadt, E. (2008, March 20). The secret to happiness? Giving. Retrieved January 24, 2011, from Science Now, http://news.sciencemag.org/sciencenow/2008/03/2002.html?sms_ss=twitter

Zaleski, P. A., \& Zech, C. E. (1992). Determinants of contributions to religious organizations: Free riding and other factors. American Journal of Economics and Sociology, 51(4), 459-472.

Zaleski, P. A., \& Zech, C. E. (1994, December). Economic and attitudinal factors in Catholic and Protestant religious giving. Review of Religious Research, 158-167. 
VITA

\section{TERRY A ZEITLOW}

Education:

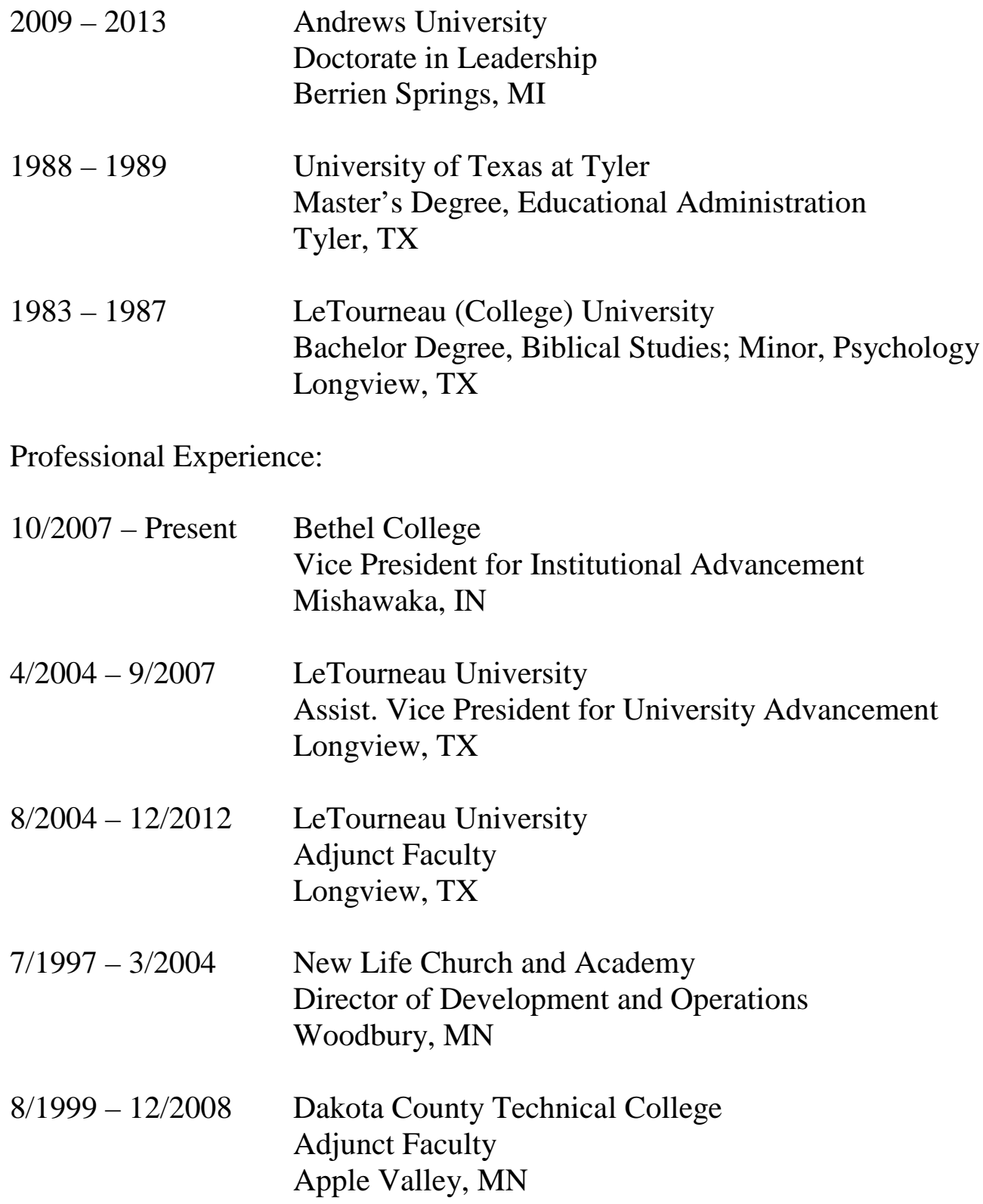

Professional Experience: 
7/1990 - 6/1997 Fort Wayne Area Youth for Christ Direct Ministry (1990-93); Projects Coord. (1994-1997)

Fort Wayne, IN

5/1987 - 6/1990 LeTourneau University

Head Men’s Basketball Coach and Resident Director

Longview, TX

Professional Affiliations:

2006 - Present $\quad$ Certified Fund Raising Executive (CFRE)

Completed Initial Qualifications and Exam (2006)

Three Year Renewal - 2009, 2012

2006 - Present $\quad$ Christian Leadership Alliance (CLA)

1996 - Present $\quad$ Ordained Minister, Colony Heights Church of Christ

Current Volunteer Experience:

1998 - Present $\quad$ Crown Ministries, Small Group Leader and Budget Coach

2007 - Present $\quad$ Rotary: South Bend Downtown Club/Edison Lakes Club

2009 - Present $\quad$ Small Group Discipleship Leader, Bethel College

Previous Volunteer Experience:

2009 - $2012 \quad$ Board Member, Michiana YMCA

5/2012 - 12/2012 Faculty Search Committee, Andrews University

2004 - 2007 Downtown Rotary Club, Longview, TX

2005 - $2007 \quad$ Elder, Longview Christian Church, Longview, TX

2007

Planning Board, Leadership Longview, Longview, TX

Achievements and Honors:

2011 Rotary Paul Harris Fellow

2006 Graduate, Leadership Longview

$2004 \quad$ Patricia A. Wiens Leadership Award 
NCCAA All-American Team 